VILNIAUS GEDIMINO TECHNIKOS UNIVERSITETAS

Rytis RAINYS

\title{
REGIONŲ INTERNETO TINKLO INFRASTRUKTŪROS PATIKIMUMO TYRIMAI
}

DAKTARO DISERTACIJA

TECHNOLOGIJOS MOKSLAI,

ELEKTROS IR ELEKTRONIKOS INŽINERIJA (01T)

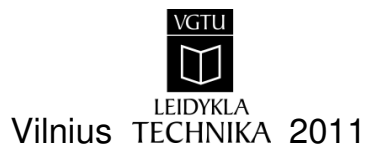


Disertacija rengta 2007-2011 metais Vilniaus Gedimino technikos universitete.

\section{Mokslinis vadovas}

prof. habil. dr. Algimantas KAJACKAS (Vilniaus Gedimino technikos universitetas, technologijos mokslai, elektros ir elektronikos inžinerija - 01T).

VGTU leidyklos TECHNIKA 1926-M mokslo literatūros knyga http://leidykla.vgtu.lt

ISBN 978-609-457-014-8

(C) VGTU leidykla TECHNIKA, 2011

(C) Rytis, Rainys, 2011 rytis.rainys@el.vgtu.lt 
VILNIUS GEDIMINAS TECHNICAL UNIVERSITY

Rytis RAINYS

INVESTIGATION OF THE REGIONAL INTERNET NETWORK INFRASTRUCTURE DEPENDABILITY

DOCTORAL DISSERTATION

TECHNOLOGICAL SCIENCES,

ELECTRICAL AND ELECTRONIC ENGINEERING (01T)

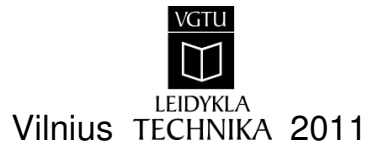


Doctoral dissertation was prepared at Vilnius Gediminas Technical University in 2007-2011.

\section{Scientific Supervisor}

Prof Dr Habil Algimantas KAJACKAS (Vilnius Gediminas Technical Univesity, Technological Sciences, Electrical and Electronic Engineering - 01T). 


\section{Reziumè}

Disertacijoje nagrinejjama interneto tinklo infrastruktūros patikimumo problematika, analizei naudojant tinklo topologijos tyrimus, grafų teorijos taikymą ir tinklo modeliavimą. Tyrimų objektas, interneto tinklo infrastruktūra, kurios pagrindą sudaro autonominès sistemos ir tarptinklinių sujungimų linijos. Nuo stabilios interneto tinklo veiklos priklauso informacijos pasiekiamumas, elektroninè komercija, nutolusių objektų valdymas ir t. t. Pagrindinis disertacijos tikslas - sukurti metodikas ir algoritmus, skirtus interneto tinklo infrastruktūros analizei bei veiklos patikimumo kontrolei. Tyrimų taikymo sritis - interneto tinklo veiklos tęstinumo priežiūra ir reguliavimas.

Darbe sprendžiami šie pagrindiniai uždaviniai: interneto tinklo topologijos analizès modelio ir priemoniu sudarymas; interneto junglumo tyrimas siekiant identifikuoti kritinius elementus, kurių pažeidimai susiję su tinklo funkcionalumo praradimu; kritinių interneto tinklo elementų stebėsenos modelio sudarymas; eksperimentiniai kibernetinių atakų simuliacijos bandymai; bei interneto tinklo infrastruktūros patikimo stiprinimo parinkimas.

Disertaciją sudaro ịvadas, 5 skyriai, rezultatų apibendrinimas, naudotos literatūros ir autoriaus publikacijų disertacijos tema sąrašai bei priedai.

Ivadiniame skyriuje aptariama tiriamoji problema, darbo aktualumas, aprašomas tyrimų objektas, formuluojamas darbo tikslas bei uždaviniai, aprašoma tyrimų metodika, darbo mokslinis naujumas, darbo rezultatų praktinè reikšmé, ginamieji teiginiai. Ivado pabaigoje pristatomos disertacijos tema autoriaus paskelbtos publikacijos ir pranešimai konferencijose bei disertacijos struktūra.

Pirmasis skyrius skirtas literatūroje aprašytų metodų, susijusių su tinklų ir informacijos saugumo incidentų valdymu apžvalgai bei CERT modelio optimizavimui. Skyriaus pabaigoje formuluojamos išvados ir tikslinami disertacijos uždaviniai. Antrajame skyriuje analizuojama interneto tinklo topologija taikant grafų teoriją, pasiūlytas autonominių sistemų ir jų sujungimo linijų klasifikavimas. Trečiasis skyrius skirtas kritinių interneto tinklo infrastruktūros elementų paieškos metodikos sudarymui ir taikymui. Pasiūlyta metodika bei algoritmas tokių elementų stebėsenai. Ketvirtajame skyriuose modeliuojama ir tiriama kibernetinių atakų ịtaka interneto tinklo infrastruktūros funkcionalumui. Penktajame skyriuose tyrimais gauti rezultatai sudaro prielaidas formuluoti priemones interneto tinklo infrastruktūros patikimui stiprinti bei formuoja regiono interneto ateities reguliavimo ir vystymo gaires.

Disertacijos tema paskelbti 6 straipsniai: du - tarptautinių konferencijų medžiagoje, keturi - recenzuojamame moksliniame žurnale (Thomson ISI Web of Science). Disertacijos tema perskaityti 9 pranešimai Lietuvos bei tarptautinèse konferencijose. 


\section{Abstract}

The dissertation investigates the issues of dependability of the Internet network infrastructure that were studied by using the network topology analysis, graph theory and network modelling. The object of the study is the Internet network infrastructure, based on autonomous systems and interconnecting lines. Stable functioning of the Internet network determines the availability of information, electronic commerce, control of remote objects, etc. The main objective is to develop the methodologies and algorithms for analysing the Internet network infrastructure and controlling the reliability of functioning. The scope of application of the study is the supervision and regulation of continuity of the Internet.

The following main tasks are solved: development of the topological scheme of the Internet network, selection of models and tools for analysis; the Internet network connectivity analysis for the purpose of identification of the critical network elements, whose violations would result in loss of connectivity of the network; as well as development of the model for monitoring of the critical elements of the Internet network and cyber-attacks simulation experiments.

The scientific work consists of the general characteristic of the dissertation, 5 chapters, conclusions, list of literature, list of publications and annexes.

The introduction reveals the investigated problem, importance of the thesis and the object of research and describes the purpose and tasks of the paper, research methodology, scientific novelty, the practical significance of results examined in the paper and defended statements. The introduction ends in presenting the author's publications on the subject of the defended dissertation.

The first chapter is dedicated to the santific researches of the networks and information security incidents management model (CERT) overview ant its optimization. The second chapter analyzes the topology of the Internet network by applying the columns theory and suggests a classification of autonomous systems and their connecting lines. The third chapter is dedicated to the development and application of the methodology for searching for the critical elements of the Internet network infrastructure. A methodology and algorithm for elements monitoring is suggested. In the fourth chapter the impact of cyber-attacks on the functioning of the Internet network infrastructure is modeled and examined. Fifth chapters covers the measures for the improvements of Internet network dependability and forms future internet regulation perspective.

6 articles focusing on the subject of the discussed dissertation are published: 4 articles - in scientific papers in the Thomson ISI register, 2 articles - in conference materials. 9 presentations on the subject have been given in conferences at national and international level. 


\section{Žymèjimai}

\section{Simboliai}

$A$ - tinklo vartotojų skaičius;

$B w$ - bendra $i$-osios AS pralaida visiems sujungimams, $\mathrm{Gb} / \mathrm{s}$;

$C_{i}$ - grupavimo koeficientas;

$\operatorname{deg}\left(V_{i}^{k}\right)-k$-osios viršūnès $V_{i}^{k}$ laipsnis;

$\operatorname{deg}_{\text {in }}\left(V_{i}^{k}\right)$ - mazgų laipsnių pasiskirstymą vidiniams Transit tipo sujungimams;

$\operatorname{deg}_{\text {out }}\left(V_{i}^{k}\right)$ - mazgų laipsnių pasiskirstymą išoriniams Transit tipo sujungimams;

$E_{\mathrm{c}}$ - kritinè linija;

$G_{\text {net }}-$ multigrafas;

$M_{i}$ - briaunų skaičius;

$N_{i}$ - mazgų skaičius;

$N(h)$ - kaiminystès funkcija;

$\eta_{i}$ - mazgo svarbos indeksas;

$\eta_{A S}-$ linijos svarbos indeksas; 
$\Delta_{\max }$ - ribinè linijos pralaida, $\mathrm{Gb} / \mathrm{s}$;

$\Delta_{\text {traffic }}-n$-osios linijos duomenų srautas, $\mathrm{Gb} / \mathrm{s}$;

$\lambda_{n}-$ linijos apkrovos koeficientas;

$p$ - tikimybe், kad kiekvienos briaunos galas per viršūnę gali turèti sujungimą su kita briauna;

$P_{\mathrm{ka}}(t)$ - klaidingo aliarmo tikimybe;

$P_{\text {na }}(t)$ - netikro aliarmo tikimybe;

$P(\mathrm{k})$ - mazgo laipsnio skirstinys;

$V_{\mathrm{c}}$ - kritinis mazgas;

$V$ - grafo viršūne;

$U$ - grafo briauna;

$u(\mathrm{k})$ - Laplaso faktorius.

\section{Santrumpos}

AS - autonominè sistema;

BGP - tinklų maršrutizacijos protokolas, telekomunikacinis terminas pagal angl. Border Gateway Protocol;

CERT - kompiuterinių incidentų reagavimo tarnyba, telekomunikacinis terminas pagal angl. Computer Emergency Responce Team;

DPS - dinaminio priartejimo sistema;

GSM - globalus mobilaus ryšio standartas, telekomunikacinis terminas pagal angl. Global Standart for Mobile Communications;

HTTPS - saugus protokolas aprašantis informaciją pasiekiamumą tinkle, telekomunikacinis terminas pagal angl. HyperText Transfer Protocol Secure;

ICMP - interneto kontrolès žinučių protokolas, telekomunikacinis terminas pagal angl.

Internet Control Message Protocol;

IIS - išankstinio įspejjimo sistema;

IP - interneto protokolas;

IT - informacinès technologijos;

IPT - interneto prieigos teikèjas;

IRT - informacijos ir ryšių technologijos;

IDS - issiskverbimo detektavimo sistema;

LMMM - lygiaverčių mainų maršrutizavimo mazgas;

VIB - valdymo informacijos bazé;

OS - operacinè sistema;

PAAA - paskirstyta atsisakymo aptarnauti ataka;

viii 
PHP -dinaminè interpretuojama programavimo kalba, kompiuterijos terminas pagal angl. Hypertext Preprocessor;

PSTN - viešas komutacinis telefoninio ryšio tinklas, telekomunikacinis terminas pagal angl. Public Switched Telephone Network;

SCADA - nuotolinės skaitmeninès objektų ir procesų kontrolès sistemos, telekomunikacinis terminas pagal angl. Supervisory Control And Data Acquisition;

SMS - trumpujų žinučių paslaugos standartas, telekomunikacinis terminas pagal angl. Short Message Service;

SNMP - paprastasis tinklų valdymo protokolas, telekomunikacinis terminas pagal angl. Simple Network Management Protocol;

SQL - struktūrizuotų užklausų programavimo kalba, kompiuterijos terminas pagal angl. Structured Query Language;

TCP - transporto kontrolès protokolas, telekomunikacinis terminas pagal angl. Transmission Control Protocol;

WDM - bangos ilgių sutankinimo tinklai, telekomunikacinis terminas pagal angl. Wavelength-division multiplexing;

WEP - privatumo bevieliam ryšiui ekvivalentas, telekomunikacinis terminas pagal angl. Wired Equivalent Privacy;

WPA - apsaugota bevielio ryšio prieiga, telekomunikacinis terminas pagal angl. Wireless Protected Access. 


\section{Turinys}

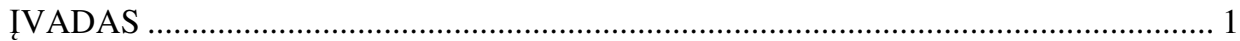

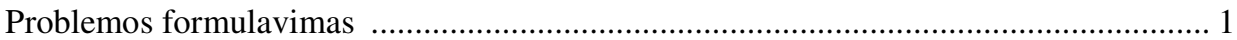

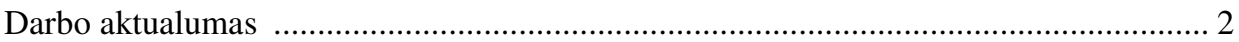

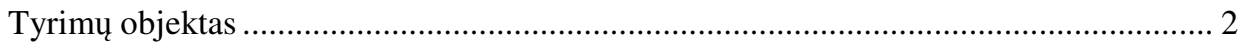

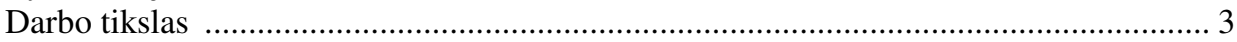

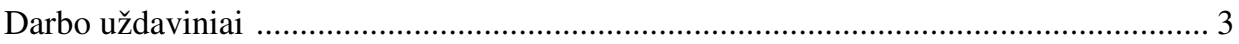

Tyrimų metodika .......................................................................................... 3

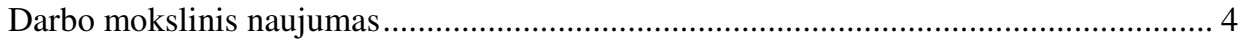

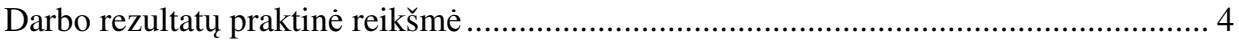

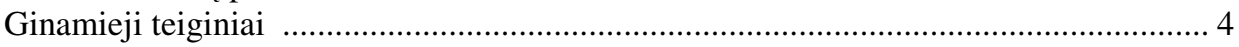

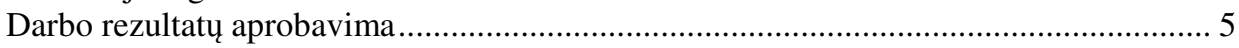

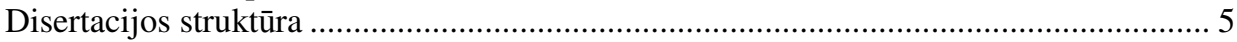

1. SAUGUMO INCIDENTŲ VALDYMO MODELIO APŽVALGA ……................... 7

1.1. Grèsmès interneto tinklo saugumui ...................................................................... 7

1.2. Incidentų valdymo modelių literatūros apžvalga ir praktikos analizė .................... 10

1.3. Apibendrintasis incidentų valdymo modelis ........................................................ 16

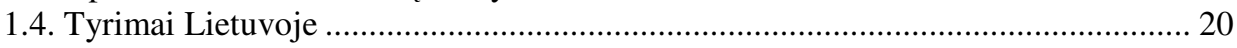

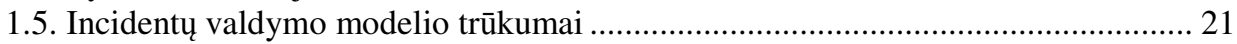

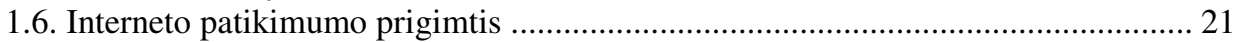

1.7. Pirmojo skyriaus išvados ir disertacijos uždavinių formulavimas ......................... 21 
2. INTERNETO TINKLO INFRASTRUKTŪROS TOPOLOGIJOS TYRIMAI ...... 25

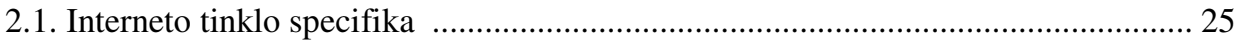

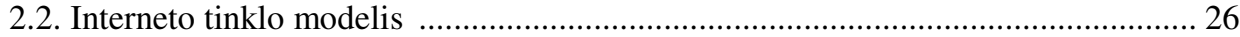

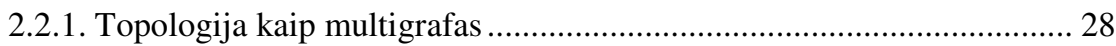

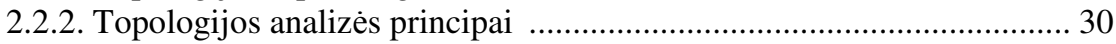

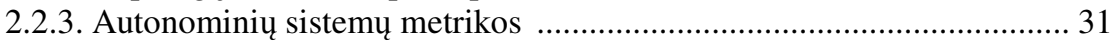

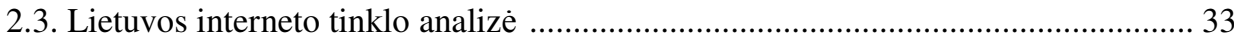

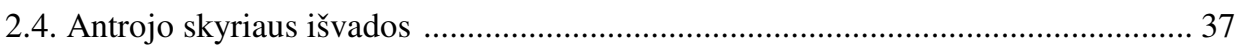

3. KRITINIŲ INTERNETO INFRASTRUKTŪROS KOMPONENTŲ

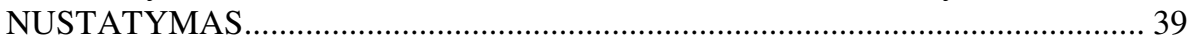

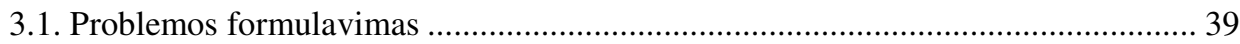

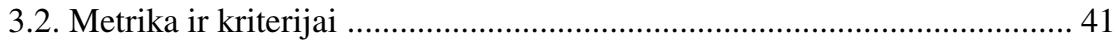

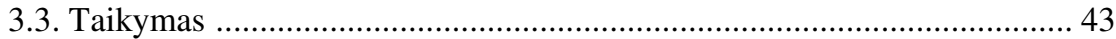

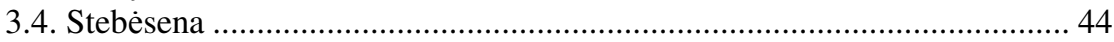

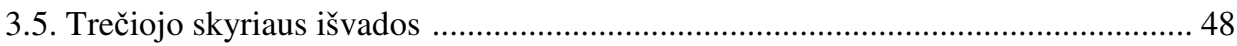

4. KIBERNETINIŲ ATAKŲ İTAKA INTERNETO FUNKCIONALUMUI............... 51

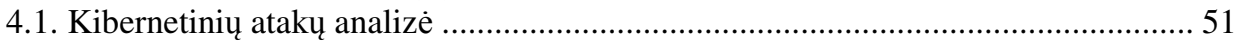

4.2. Kibernetinių atakų simuliacijos internetui modelis ............................................... 55

4.3. Eksperimentiniai rezultatai .......................................................................... 55

4.3.1. Srauto generavimo kibernetine ataka .................................................... 55

4.3.2. Tranzitinio mazgo kibernetinè ataka ......................................................... 57

4.3.3. Lygiaverčių mainų mazgo kibernetinè ataka ......................................... 58

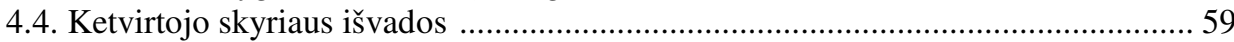

5. REGIONO INTERNETO TINKLO PATIKIMUMO STIPRINIMAS .................... 61

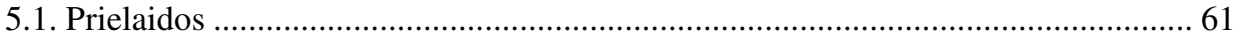

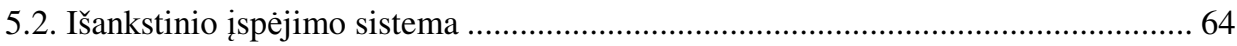

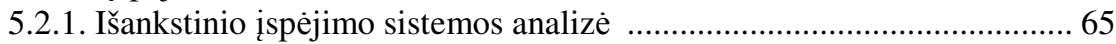

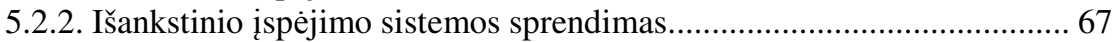

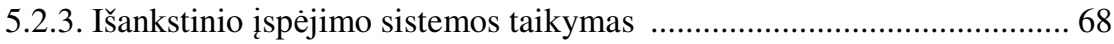

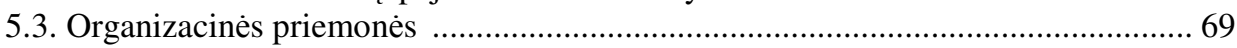

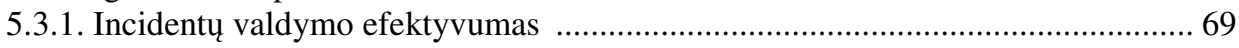

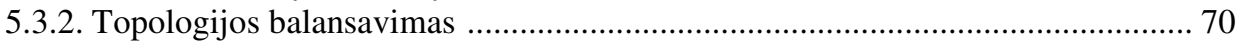

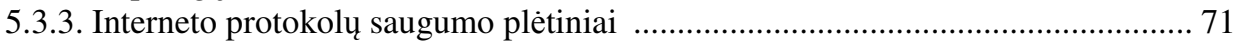

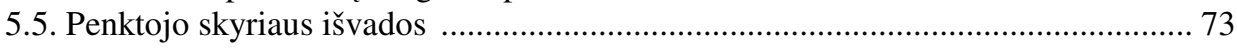

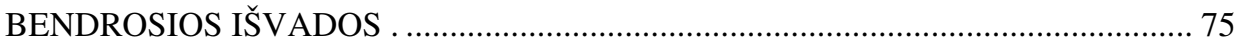

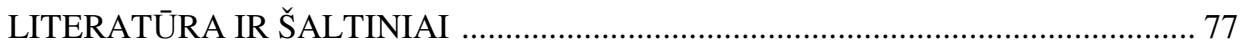

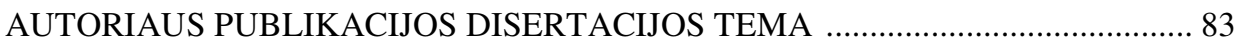


PRIEDAI 85

A priedas. Pilna realios Lietuvos interneto tinklo topologijos schema 85 B priedas. Virtualus Lietuvos interneto tinklo modelis kibernetinių ataku eksperimentams 


\section{Contents}

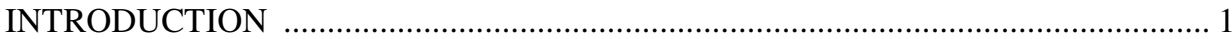

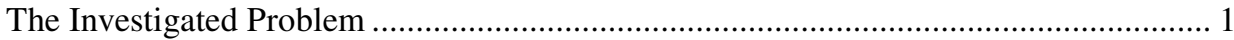

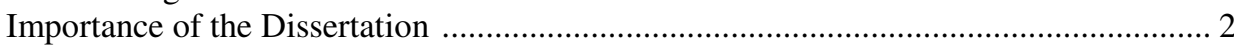

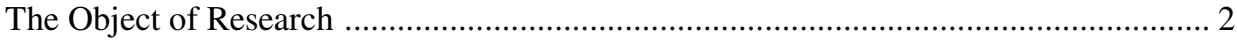

Objective of the Work ……….......................................................................... 3

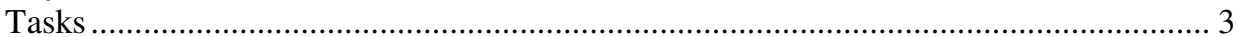

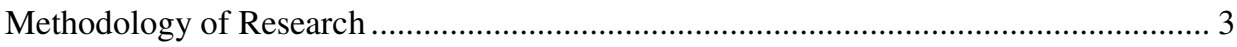

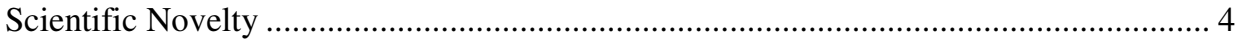

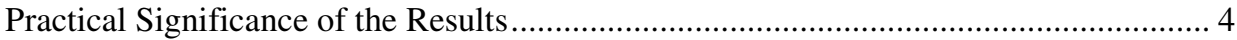

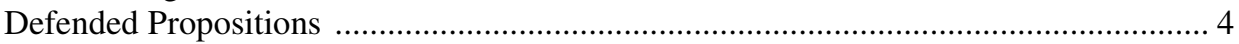

Approbation of the Results …………............................................................ 5

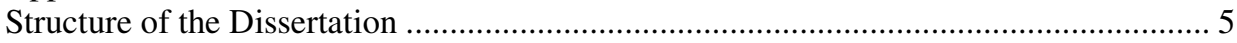

1. OVERVIEW OF SECURITY INCIDENTS MANAGEMENT MODEL ................ 7

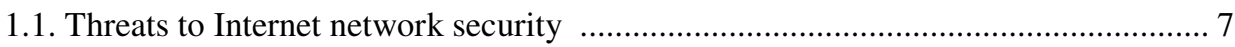

1.2. Incidents management model researches overview ............................................. 10

1.3. Consolidated incidents management model ………............................................ 16

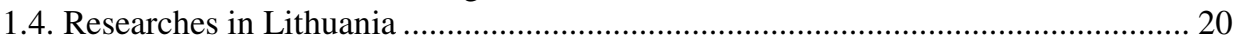

1.5. Limitations of incidents management model ………............................................. 21

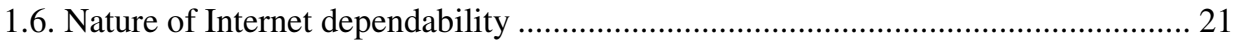

1.7. Conclusions of Chapter 1 and tasks formulation.................................................. 21 


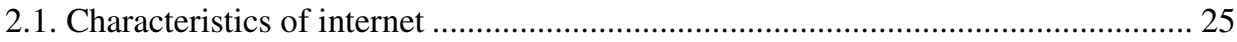

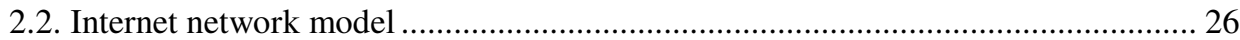

2.2.1. Topology as multigragh. ......................................................... 28

2.2.2. Principles of topology assesment................................................ 30

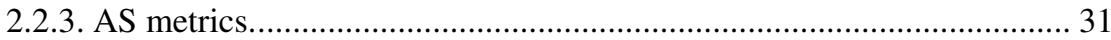

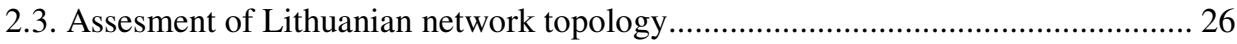

2.4. Conclusions of Chapter 2 ............................................................................. 38

3. ESTIMATION OF CRITICAL COMPONENTS OF THE INTERNET

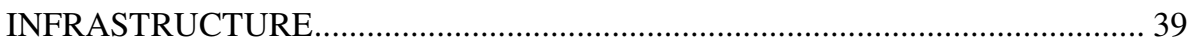

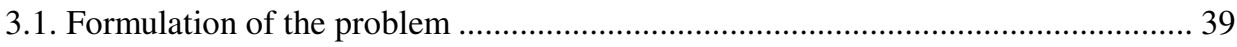

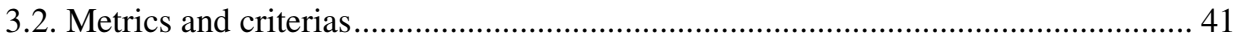

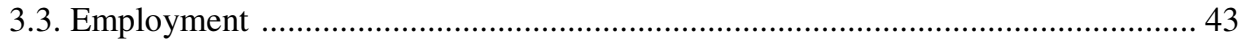

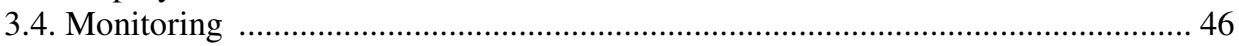

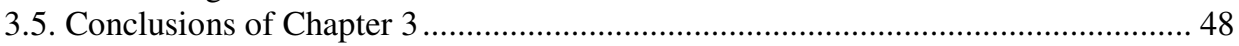

4. CYBER ATTACKS INFLUENCE TO THE INTERNET FUNCTIONALITY ..... 51

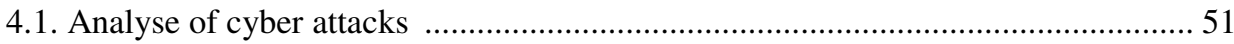

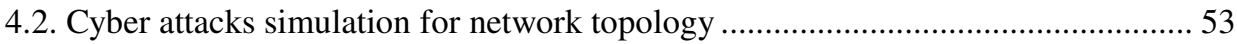

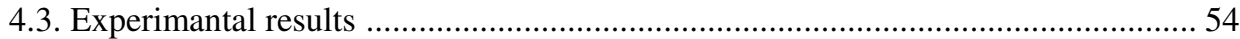

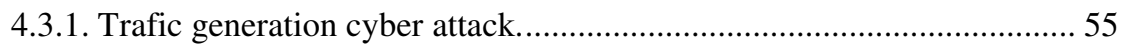

4.3.2. Transit node cyber attack......................................................... 57

4.3.3. Peering node cyber attack. ......................................................... 59

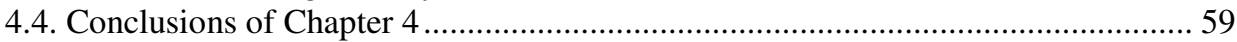

5. DEPENDABILITY CONSOLIDATION FOR REGIONAL INTERNET

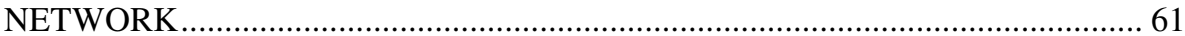

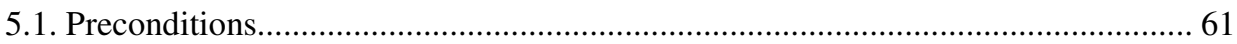

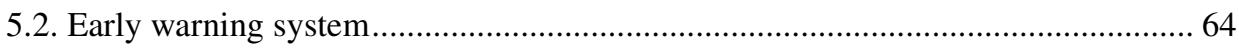

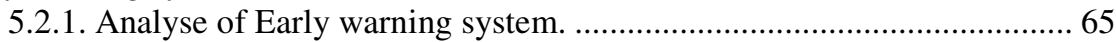

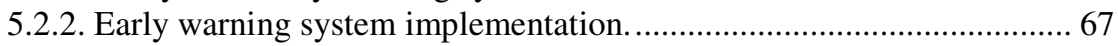

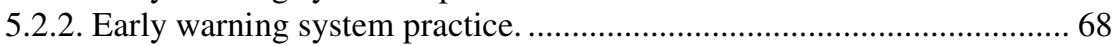

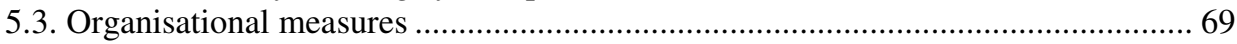

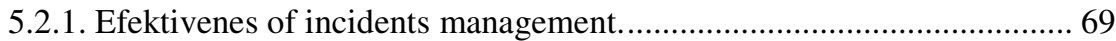

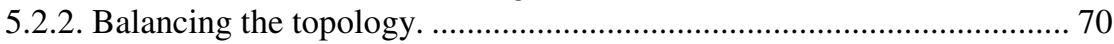

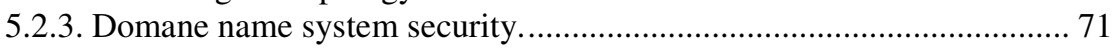

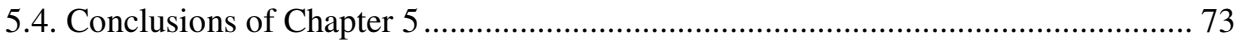

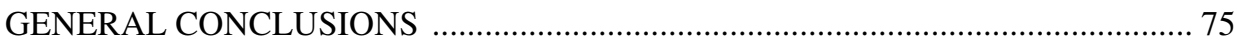

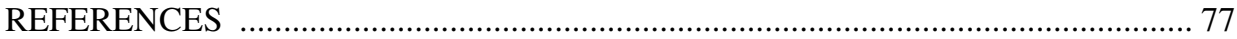


LIST OF THE AUTHOR'S SCIENTIFIC PUBLICATIONS ON THE TOPIC OF DISSERTATION

ANNEXES

85

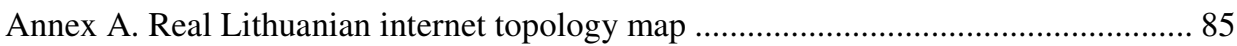

Annex B. Virtual Lithuanian internet topology map for cyber attacks simulation ........ 86 
Xviii 


\section{Ivadas}

\section{Problemos formulavimas}

Informacijos ir ryšių technologijos (IRT) yra reikšmingas ịrankis kuriant inovacijas, socialinę ir ekonominę šalies gerovę. IRT ir konkrečiai interneto technologijos visapusiškai integruotos e. versle, e. bankininkystėje, e. valdžios paslaugose. Interneto tinklas yra ypatingos svarbos nacionalinè infrastruktūra, todél didejjantis kibernetinių atakų intensyvumas bei technologinių tinklo grandžių sutrikimai kelia poreikị ištirti interneto saugumą ir jo veiklos patikimumą. Šiuo darbu siekiama spręsti elektros ir elektronikos inžinerijos mokslo krypties problematiką, susijusią su interneto tinklo patikimumu.

Esama interneto tinklo infrastruktūra susiformavo ir toliau vystosi stochastiškai, be sistemingos duomenų srautu bei pralaidumų analizès, be sistemingo tinklo projekto. Regionų interneto tinklus sudaro atsitiktinai sujungti potinkliai, kurie formuoja komplikuotą tarptinklinių ryšių topologiją su dideliu skaičiumi mazgų ir jungčių tarp jų. Nėra žinoma ar pakankami tinklo mazgų bei jungiamųjų kanalų pralaidumai, ar tie pralaidumai pakankami esant atskirų mazgų bei kanalų gedimams, ar jie pakankami atsitiktinai padidejjus duomenų srautams ir kibernetinių atakų atvejais. Siekiant valstybès mastu įvertinanti interneto tinklo galimybes, jo patikimumą, būtina atlikti išsamius viso tinklo infrastruktūros tyrimus. 
Interneto tinklas veikia didejjančioje kibernetinių atakų ir saugumo pažeidimų aplinkoje. Kartu su pirmomis rimtomis grèsmėmis interneto saugumui, sukurtas reagavimo ị saugumo incidentus kompiuteriu tinkluose CERT modelis, kuris tobulinamas iki šiol. Tačiau pastebèta, kad CERT modelis, būdamas efektyvus sprendžiant atskirus saugumo incidentus, nėra tinkamas metodas spręsti sisteminius interneto tinklo saugumo ir patikimumo klausimus. Kyla poreikis pasirinkti ir vystyti naujas, pro-aktyvias (prevencines) priemones, kurios sudarytų sąlygas mažinti interneto pažeidžiamumą ar neutralizuoti kibernetinių incidentų įtaką internetui.

\section{Darbo aktualumas}

Globalaus interneto moksliniai tyrimai vykdomi nuo tinklo sukūrimo pradžios. Šie tyrimai apima tinklo dedamuju - autonominių sistemų analizę, tarptinklinių sujungimų topologijos optimizavimo metodus. Tačiau nèra sistemingų tyrimų kaip tirti ir analizuoti iš stochastiškai sujungtų potinklių susiformavusị regiono ar valstybès interneto tinklą kaip bendrą vientisą sistemą. Pristatomoje disertacijoje sprendžiama ịvardinta problema ir tuo sukuriama nauja interneto tyrimų kryptis. Darbe atlikti tyrimai ir sukurtos metodikos papildo interneto tyrimų metodikas bei priemones.

Šiuo darbu ieškoma būdų, kaip galima objektyviai vertinti regiono interneto tinklo patikimumą, kuriama metodika, skirta nustatyti interneto veiklos nenutrūkstamumo bei kokybès palaikymo rodiklius. Šios problemos sprendimo rezultatai turi didelę reikšmę kuriant interneto tinklo veiklos patikimumo vertinimo praktiką.

Disertacijoje atlikti interneto tinklo infrastruktūros pažeidžiamumo tyrimai ir sudaryta metrika interneto tinklo patikimui vertinti. Metodai, paremti grafų teorija, tinklo modeliavimu, statistine analize bei eksperimentiniais bandymais, leidžia spręsti tinklo analizės uždavinius tais atvejais, kai objekto modelis yra sudètingas arba jo potinkliai sujungti atsitiktinai, kai nėra pilnai žinomos tinklo statistinès charakteristikos.

Darbo rezultatai yra aktualūs šalies ir tarptautinèms telekomunikacijų priežiūros ir reguliavimo institucijoms, nes padeda ịvertinti esantị interneto tinklo infrastruktūros pažeidžiamumą. Taip pat sudaro prielaidas telekomunikacijų reguliavimo institucijoms pritaikyti mokslinius metodus interneto tinklo infrastruktūros patikimumo kontrolei bei ateities interneto patikimumo stiprinimui.

Darbas taip pat aktualus krašto apsaugos tarnyboms. Telekomunikacijos ir internetas yra nacionalinis resursas. Kadangi auga kibernetiniu atakų įtaka interneto tinklo funkcionalumui, o NATO elektroninę erdvę paskelbė penktaja gynybos dimensija, interneto saugumo užtikrinimas yra ir šalies gynybos plano dalis. 


\section{Tyrimų objektas}

Darbo tyrimų objektas - iš anksto apibrežto (geografiškai išreiškiamo grafo briaunų ir viršūnių visuma) regiono interneto tinklo infrastruktūra, sudaryta iš tarpusaviu sujungtų autonominių sistemų (AS) ir lokaliųjų tinklų. Praktiškai ištirtas Lietuvos interneto tinklas sudarytas iš 40 AS, 27 lokalių potinklių, 490 tarptinklinių jungčių (tarp jų 373 lygiaverčių mainų tipo ir 117 tranzitinès jungtys).

\section{Darbo tikslas}

Ištirti ir išanalizuoti iš stochastiškai sujungtu potinklių susiformavusį regiono ar valstybės interneto tinklą kaip bendrą sistemą ir pasiūlyti būdus kaip nustatyti ir stebèti tokios sistemos patikimumo bei veiklos nenutrūkstamumo rodiklius.

\section{Darbo uždaviniai}

Darbo tikslui pasiekti siekiama išspręsti sekančius uždavinius:

1. Sudaryti interneto tinklo topologijos analizès modelị bei priemones.

2. Sukurti metodus interneto tinklo infrastruktūros kritiniams elementams, kurių pažeidimai būtų susiję su ženkliu tinklo funkcionalumo praradimu, nustatyti.

3. Sudaryti kritinių interneto tinklo infrastruktūros elementų stebėsenos modelį ir jo veiklos algoritmą.

4. Sumodeliuoti virtualų regiono interneto tinklą bei išbandyti jo pažeidžiamumą simuliuojant kibernetines atakas.

5. Suformuluoti priemones interneto tinklo infrastruktūros patikimumui stiprinti.

\section{Tyrimų metodika}

Darbe taikomi sistemų modeliavimo, grafų teorijos ir statistinès analizès metodai. Hipotezès tikrinamos sudarant modelius ir atliekant simuliacijas, vykdant eksperimentinius tyrimus. 


\section{Darbo mokslinis naujumas}

Rengiant disertaciją buvo gauti šie telekomunikacijų inžinerijos mokslui reikšmingi rezultatai:

1. Sukurta metodika regiono interneto tinklo infrastruktūros patikimumui tirti, kuri naudojant ryšių grafų teoriją geriau ịvertina tinklo topologijos pažeidžiamumus. Aprašyta Lietuvos interneto tinklo topologija, įvertinti patikimumo rodikliai.

2. Sudaryta metrika kritinių Interneto tinklo infrastruktūros elementų identifikavimui. Taikant šią metriką gauti rezultatai regiono Interneto tinklui.

3. Atlikta Interneto tinklo infrastruktūros topologijos modelio analizè taikant kibernetinių atakų simuliacijos eksperimentus.

4. Pasiūlytas kritinių Interneto tinklo infrastruktūros elementų stebėsenos modelis ir jo veiklos algoritmas.

\section{Darbo rezultatų praktinè reikšmè}

Darbe sukurta universali tyrimų metodika ir metrika gali būti naudojamos įvairių interneto tinklo sričių (regionų) infrastruktūros patikimumo tyrimams, kritinių interneto tinklo infrastruktūrų elementams identifikuoti ir jų tolesnei stebėsenai atlikti. Nacionalinès elektroninių ryšių reguliavimo ir priežiūros institucijos, remiantis darbe aprašytais metodais, praktiškai vertina interneto tinklo patikimumo bei saugumo rodiklius.

Tyrimų rezultatai įvertinti Lietuvos Respublikos ryšių reguliavimo tarnyboje ir naudojami vykdant nacionalinį elektroninių ryšių reguliavimą. Išbandytas darbe pasiūlytas kritinių interneto tinklo infrastruktūros elementų stebėsenos modelis laboratorijos sąlygomis.

Darbo rezultatai ir vaizdiniai pristatymai demonstruoti Tarptautinei Telekomunikacijų Sajungai (ITU), Europos tinklų ir informacijos saugumo agentūrai (ENISA), Europos šalių reguliavimo institucijoms bei Lietuvos Respublikos krašto apsaugos ministerijai.

\section{Ginamieji teiginiai}

1. Realūs interneto regionų tinklai susidaro stochastiškai sujungiant autonomines sistemas, todèl jų linijų bei mazgų pralaidumai ne visada atitinka informacinių srautų intensyvumus.

2. Interneto tinklo infrastruktūros grandžių pažeidžiamumą gerai atspindi kritiniai elementai: kritinis ir $\eta$-kritinis mazgas, kritine ir $\kappa$-kritinè linija. 
3. Interneto infrastruktūra nuolat kinta, todèl jos stebèsenai ir patikimumui vertinti reikalingas nuolat atnaujinamas analizuojamo regiono tinklo struktūrinis modelis.

4. Regioninio interneto tinklo būsenai stebėti bei kibernetinių atakų ịtakai analizuoti geriausiai tinka kritinių tinklo elementų stebėsenos realiuoju laiku metodas bei kibernetinių atakų simuliacijos eksperimentai.

\section{Darbo rezultatų aprobavimas}

Disertacijos tema yra spausdinti 6 moksliniai straipsniai: keturi - mokslo recenzuojamuose žurnaluose Thomson ISI Web of Science (Rainys 2006, 2010, 2011), du - recenzuojamuose tarptautinių konferencijų medžiagoje (Rainys 2006, 2007).

Disertacijoje atliktų tyrimų rezultatai buvo paskelbti devyniose mokslinėse konferencijose Lietuvoje ir užsienyje:

- Jaunujų mokslininkų konferencijoje „Lietuva be mokslo - Lietuva be

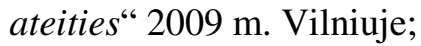

- Tarptautineje konferencijoje „Elektronika“ 2007, 2008, 2010 m. Vilniuje. 2010 m. IEEE Lithuanian Section SP/CIS/COM Joint Chapter skirta 1-sios vietos pažyma geriausio jaunojo mokslininko pranešimo konkurse;

- Tarptautinejje konferencijoje „Informacinès technologijos“ $2007 \mathrm{~m}$. Kaune;

- Tarptautinèje konferencijoje „Information Security Solutions Europe“ 2006 m. Romoje;

- Tarptautineje IEEE/IST konferencijoje „Monitoring, Attack Detection and Mitigation" $2006 \mathrm{~m}$. Tubingene;

- Tarptautinèje konferencijoje „Future of Broadband“ 2010 m., Stambule;

- Tarptautineje konferencijoje „Cyber Conflict“ 2010 m., Taline.

\section{Disertacijos struktūra}

Disertaciją sudaro ịvadas, penki skyriai ir rezultatų apibendrinimas. Taip pat yra du priedai.

Darbo apimtis yra 84 puslapiai, neskaitant priedų, tekste panaudotos 9 numeruotos formulès, 21 paveikslas ir 7 lentelès. Rašant disertaciją buvo panaudoti 91 literatūros šaltiniu. 


\section{Padèka}

Išreiškiama autoriaus padèka moksliniam vadovui prof. habil. dr. Algimantui Kajackui, kurio mokslinès ịžvalgos, rekomendacijos ir sistemingas vadovavimas reikšmingai prisidejo kuriant ir realizuojant mokslinius tyrimus šios disertacijos kontekste.

Taip pat dėkoju Lietuvos Respublikos ryšių reguliavimo tarnybai už mokslo darbų įvertinimą ir panaudojimą praktikoje vykdant elektroninių ryšių tinklų ir informacijos saugumo priežiūrą Lietuvos Respublikoje. 


\section{1}

\section{Saugumo incidentų valdymo modelio apžvalga}

Skyriuje analizuojami aktualūs interneto tinklo saugumo aspektai: nepritaikytas aukštiems saugumo reikalavimams interneto protokolai, augantis informacinių sistemų kompleksiškumas, saugumo pažeidžiamumai programinèje įrangoje, botnet tinklai, debesų technologijų naudojimas ir pan. Apžvelgiamas CERT modelis, skirtas saugumo incidentų tyrimams ir reagavimui, ypač kai yra potenciali rizika tinklo funkcionalumui ar duomenų saugumui. Sudarytas optimizuotas CERT modelis regiono interneto tinklo saugumo priežiūrai.

Skyriaus tematika paskelbti du autoriaus straipsniai (Rainys 2006, Rainys 2007).

\subsection{Grèsmès interneto tinklo saugumui}

Augantis informacinių technologijų (IT) naudojimas lemia ir didesnių grèsmių joms atsiradimą. Besiplečiančių IT galimybių spektras veiksmingai išnaudojamas naudojant interneto tinklo platforma. Tačiau negalima nepaisyti vienos iš pagrindinių šios srities problemų - saugumo užtikrinimo. interneto tinklas ir jo pagrindu veikiančios IT susiduria su augančiu incidentų virtualioje erdvejje skai- 
čiumi ir kibernetinių atakų mastu bei profesionalumu (Hanley 2011, Libicki 2009).

Saugumo incidentų įtaka elektroninių ryšių tinklams nuolat auga ir prognozuojama, kad ateityje incidentų tik daugès. Susidariusias grèsmes saugumui lemia kelios esminès priežastys:

1. Interneto tinklo kūrimo pradžioje, nebuvo tikslo tinklą adaptuoti aukštiems saugumo reikalavimams. Tačiau dabar interneto saugumas tapo aktuali problema. Projektavimo metu buvo siekiama paprasto ir universalaus tinklo standarto, sujungiančio skirtingų tipų skaitmenines skaičiavimo mašinas ị bendrą duomenų perdavimo tinklą. Vèliau tinklas pradètas naudoti jau atskirų duomenų perdavimo tinklų sujungimui, ką ir realizavo TCP/IP protokolas (Kozierok 2005). Interneto tinklas per salyginai trumpą laikotarpi ženkliai išsiplète, tad dabar, atsiradus svarbioms saugumo problemoms, ji pakeisti kitu, saugesniu tinklu praktiškai neįmanoma. Informacinių sistemų, prijungtų prie interneto tinklo, yra milijonai, o tinklo ịrenginių, kurie pagaminti darbui TCP/IP standarto tinkluose, yra dar daugiau. Technologiškai labai sudètinga pakeisti ši techninị ūkị, todèl išlieka poreikis ieškoti kitų tinklų ir informacijos saugumo kontrolès mechanizmų tiesiogiai nekeičiant techninès įrangos.

2. Belaidžių tinklų, ypatingai veikiančių Wi-Fi technologijos pagrindu, plètra nelicencijuojamuose $2,4 \mathrm{GHz}$ ir $5 \mathrm{GHz}$ dažnių juostose kelia naujus saugumo iššūkius tinklų saugumui (Lehembre 2005). Duomenų perdavimas belaidžiu tinklu vyksta signalus skleidžiant radijo bangomis, o tai potencialiems įsibrovéliams suteikia daugiau galimybių nei ịprastiniuose laidiniuose tinkluose nuotoliniu būdu perimti duomenis iš belaidžių tinklų ir juos valdyti. Belaidžių tinklų įrangos gamykliniai nustatymai dažnu atveju nèra pritaikyti aukštiems saugumo reikalavimams (pavyzdžiui, naudojami standartiniai prisijungimo prie tinklo slaptažodžiai). Dèl šifravimo algoritme aptiktos saugumo spragos, WEP technologija neapsaugo tinklo vartotojo duomenų konfidencialumo. Esant tam tikroms sąlygoms (kai srauto duomenyse yra pakartotinai panaudojamas RC4 šifro raktas), WPA šifravimo raktas gali būti atskleistas atlikus vadinamają , ataką pagal žodyną“. WPA (angl. Wireless Protected Access) 802.11i standarto versijos realizacija, pagrịsta TKIP (angl. Temporal Key Integrity Protocol) šifravimo algoritmu, kuri buvo sukurta tam, kad pakeistų WEP (Lehembre 2005). Tačiau WPA ir WPA2 naudojama dar ne visose Wi-Fi tinklų ịrenginiuose. Statistiškai Lietuvoje belaidžių tinklų 57 \% visai nenaudoja duomenų perdavimo šifravimo arba naudoja pažeidžiamą duomenų kodavimo algoritmą WEP 16 \% (Vindašius 2006).

3. Augantis IT kompleksiškumas: internete organizuojamos atskiros verslo sistemos (vadinamasis e. verslas); bankinès operacijos perkeliamos ị internetą (e. bankininkystė); valstybinès institucijos paslaugas piliečiams taip pat perkelia $\mathfrak{i}$ elektroninę erdvę (e. vyriausybė); nuotolinès skaitmeninès objektų ir procesų 
kontrolès sistemos (literatūroje dažniausiai apibrèžiama kaip SCADA sistemos) veikia interneto tinkle taip pat. SCADA sistemos ypatingos, nes kontroliuoja gyvybiškai svarbių infrastruktūrų (kaip vandens, energijos tiekimas) darbą (Hentea 2008). Dẻl ịvairialypio informacinių sistemų kompleksiškumo ir integralumo su interneto tinklu sistemos tampa sudètingesnès ir tai didina riziką, kad tokiose sistemose atsiras daugiau saugumo spragų. Pavyzdžiui, $2010 \mathrm{~m}$. aptiktas „Stuxnet“" virusas orientuotas į SCADA komponenčiu pažeidimus. Jis pakeičia procesų valdiklių parametrus taip neautorizuotai falsifikuojant komandas ar sugadinant SCADA technologinius įrenginius (Falliere 2011).

Interneto tarptinklinių ryšių sistema yra dinamiška ir nuolat kintanti. Ji keičiasi atsirandant naujoms jungtims ir pašalinant kitas. Interneto tinklas yra labai decentralizuotas. Sprendimas dẻl tarptinklinių jungčių organizavimo priimamas pačių AS operatorių. Jungimasis priklauso nuo AS galimybių pasiekti internetą ir nuo noro būti pasiekiamam iš išorès, kai tuo tarpu techninès galimybès nèra pirmaeilès. Tuo tarpu kai duomenų srautai keičiasi, media turinio apimtys ženkliai padidejo lyginant su 2000 metais dominavusiu duomenų tipu tarp galinių taškų (Hall 2011). Atsitiktinė tarptinklinių jungčių infrastruktūros veikla ne visada gali adekvačiai akumuliuoti duomenų srautus.

4. Šiuolaikinėms kompiuterinėms sistemoms aptarnauti kuriamos didelių apimčiu programos, sudarytos iš daugybès programinio kodo eilučių. Vertinama, kad 1000 programinio kodo eilučių paprastai yra nuo 5 iki 20 klaidų. Populiarias tinklo valdymo operacines sistemas sudaro apie $40 \mathrm{mln}$. programinio kodo eilučių (Lohr 2006), tai reiškia, kad jos gali turèti nuo 175000 iki 700000 potencialių programavimo klaidų (pažeidžiamumų). Šie pažeidžiamumai programinèje ịrangoje yra išnaudojami kenksmingam programiniam kodui (virusams) ịterpti i IT sistemas.

5. Dèl programų pažeidžiamumų, laikas saugumo atakoms įvykdyti trumpèja. Pavyzdžiui, 2000 metais kompiuterinis virusas „Nimba“ pasinaudojo pažeidžiamumu Microsoft operacinèje sistemoje, atrasta beveik prieš metus, o 2004 metų virusui „Sasser“ sukurti prireikè vos 17 dienų (Ferrie 2004). Virusas „Witty“ buvo sukurtas per 1 parą po pranešimo apie programinės įrangos pažeidžiamumą. Dèl to, organizuoti reagavimo ị saugumo incidentus veiksmus lieka nedaug laiko.

6. Botnet tinklai, t. y. pažeistų ir nuotoliniu būdu valdomų per vieną ar kelis kontrolerius kompiuterių tinklas (Provos 2007, Juknius 2011). Tai didelè tinklų ir informacijos saugumo problema, nes tokie tinklai savyje apjungia iki kelių šimtų tūkstančių pažeistų kompiuterių. Juos nukreipus ị pasirinktą taikinį, galima padaryti didesnių nuostolių, negu pavienèmis atakomis.

7. Pastebima tendencija - saugumo incidentų mobilumas, atakos nukreipiamos ị mobiliuosius telefonus ir planšetinius kompiuterius. Pasaulyje mobiliujju telefonų yra daugiau kaip milijardas (daugiau, negu kompiuterių), tad pastaruoju 
metu atakos yra nukreipiamos būtent ị juos, taip padarant žalos dar didesnei tikslinei vartotojų grupei. Tyrimų duomenimis $2011 \mathrm{~m}$. kenksmingo programinio kodo apimtys išaugos 400 proc. Android išmaniujų telefonų sistemoms. 17 proc. atvejų apie aptiktus mobilius virusus sudare trumpujų žinučių SMS Trojanai kurie inicijuoja SMS žinučių automatinį siuntimą padidinto tarifo numeriais. Tik 15 proc. išmaniujų telefonų vartotojų naudoja antivirusines ar ugniasieniu programas (Juniper 2011). Tokia situacija sąlygota išaugusiu išmaniụjų telefonų vartojimu, atviro kodo operacinių sistemų (OS) tokiems įrenginiams ir didelè gausa papildomų programų (aplikacijų) turinčių saugumo pažeidžiamumus.

8. Iki šiol įmonès ir organizacijos IT ịrenginius ir jų programas ịsigydavo ir juos administruodavo pačios. Dabar yra perkamos IT paslaugos iš IT paslaugu teikejjų. Informacijos ir IT savininkai išsiskiria, informacija saugoma ir prieinama savininkui nuotoliniu būdu, o ši technologinè tendencija vadinama debesų technologijomis. Debesų technologijos ekonomiškai pasiteisina, todèl jų naudojimas sparčiai auga (Goodger 2011). Kadangi savininkas perkelia informacijos ir IT valdymą kitam subjektui, jis nebevaldo ir rizikų. Debesų technologijos saugumo aspektai: duomenų centrų saugumo užtikrinimas, perduodamų tinklais duomenų šifravimas, duomenų pasiekiamumas (t. y. ryšio nenutrūkstamumo užtikrinimas) ir visos sistemos veiklos patikimumas. Pavyzdžiui, jeigu būtų pažeistas ar sugadintas duomenų centras arba organizuota kibernetinė ataka ryšio kanalų pralaidos užblokavimui, tai atsilieptų visiems duomenų centrų vartotojams. Atsižvelgiant ị tai, debesų technologijų saugumas yra ypatingas.

\subsection{Incidentų valdymo modelių literatūros apžvalga ir praktikos analizè}

Absoliutaus saugumo bendraja prasme kompiuteryje, informacinèje sistemoje ar tinkle pasiekti praktiškai neįmanoma. Saugumas - tai tikslas, kurio turi būti siekiama visą laiką. Tvirtinama, kad šiam tikslui igyvendinti sukurta kompiuterinių incidentų reagavimo tarnyba CERT (West-Brown 2003, Killcrece 2003, Alberts 2004).

CERT, dar kitaip CSIRT (Alberts 2004) - tai tinklų ir informacijos saugumo incidentų reagavimo tarnyba, kurios pagrindinis tikslas yra operatyviai reaguoti ị saugumo incidentus elektroninių ryšių tinkle, vykdyti jų tyrimus ir koordinuoti veiksmus juos šalinant, ypač kai yra potenciali rizika tinklo funkcionalumui ar duomenų saugumui (West-Brown 2003). Elektroninejje erdvèje CERT atlieka savotišką gaisrų gesinimo komandos vaidmenị.

CERT veiklos istorija prasideda nuo $1988 \mathrm{~m}$., kai vienas pirmujų interneto kirminų (pati save tinkle platinanti kompiuterinio viruso atmaina) apkeliavo visą pasaulinị interneto tinklą ir sutrikdè daugelio IT veiklą. Tais pačiais metais buvo sukurtas pirmasis CERT (IT saugumo incidentų tyrimo grupès) modelis, kuris 
buvo užregistruotas JAV Patentų biure ir iki šiol veikia Carnegie Mellon universitete. Akademiniuose sluoksniuose sukurtas CERT veiklos modelis buvo sèkminga idejja ir tapo svarbiausiu įrankiu vykdant IT saugumo incidentų valdymą elektroninių ryšių tinkluose. Šiuo metu pasaulyje egzistuoja keli šimtai įvairaus dydžio valstybinių, komercinių bei akademinių CERT.

Autoriu (West-Brown 2003, Killcrece 2003, Alberts 2004) darbuose apibendrinamos pagrindinès CERT modelio funkcijos, kurių santrauka išdėstyta 1.1 lentelèje. Didžiają dalị šių funkcijų sudaro organizacinès priemonès, kurias galima suskirstyti ị reagavimo ir prevencijos.

1.1 lentelè. CERT modelio saugumo incidentų tyrimo funkcijos

Table 1.1. Functions of security incidents assesment for CERT model

\begin{tabular}{|c|c|c|}
\hline Tiesioginès funkcijos & Netiesioginès funkcijos & $\begin{array}{l}\text { Saugumo kokybès } \\
\text { valdymo funkcijos }\end{array}$ \\
\hline $\begin{array}{l}\text { İspėjimas apie grèsmes. } \\
\text { Incidento valdymas: } \\
\text { - incidento analizė; } \\
\text { - reagavimas ị incidentą } \\
\text { vietoje; } \\
\text { - pagalba reagavimui ị } \\
\text { incidentą; } \\
\text { - reagavimo ị incidentą } \\
\text { koordinavimas. } \\
\text { Pažeidžiamumų valdymas: } \\
\text { - pažeidžiamumo analizė; } \\
\text { - reagavimas i } \\
\text { pažeidžiamumą; } \\
\text { - reagavimo ị pažeidžiamumą } \\
\text { koordinavimas. } \\
\text { Artefaktų valdymas: } \\
\text { - artefakto analizė; } \\
\text { - reagavimas i artefaktą; } \\
\text { - reagavimo ị artefakto } \\
\text { koordinavimas. }\end{array}$ & $\begin{array}{l}\text { Pranešimai apie } \\
\text { pažeidžiamumus. } \\
\text { Technologiju stebejiimas. } \\
\text { Saugumo auditas ir } \\
\text { ìvertinimas. } \\
\text { Saugumo priemonių } \\
\text { konfigūravimas ir priežiūra. } \\
\text { Saugumo priemonių } \\
\text { kūrimas. } \\
\text { Isilaužimų detektavimas. } \\
\text { Informavimas apie } \\
\text { saugumą. }\end{array}$ & $\begin{array}{l}\text { Rizikų analizė. } \\
\text { Verslo tęstinumo ir } \\
\text { krizių likvidavimo } \\
\text { planavimas. } \\
\text { Saugumo konsultacijos. } \\
\text { Mokymai. } \\
\text { Produktų ịvertinimas ir } \\
\text { sertifikavimas. }\end{array}$ \\
\hline
\end{tabular}

Darbe (Killcrece 2003) apžvelgiant CERT organizacinius modelius, nagrinèti saugumo incidentų tyrimų būdai. Nagrinèjama iš esmės organizaciniai veiksmai, skirti valdyti saugumo incidentų tyrimo procesus. Medžiaga naudinga organizacijoms, kurios priima sprendimą kurti CERT, tačiau dar nèra apsisprendusios kokị CERT modeli pritaikyti.

Śaltinis detaliai analizuoja ir aprašo praktiškai visus galimus CERT modelių variantus, jų stipriąsias ir silpnąsias savybes. Aptariami tokie saugumo incidentų 
tyrimų realizavimo variantai:

1. Saugumo komandos modelis. Iš esmès tai nèra pilna apimtimi veikiantis CERT modelis, nes jame nenumatyta dedikuoto resurso įmonejje ar organizacijoje vykdyti saugumo incidentų tyrimus. Reagavimas $\mathfrak{i}$ saugumo incidentus nèra apibrèžtas ir nekoordinuojamas, t. y. tyrimas vyksta pagal buvusị saugumo incidento faktą.

2. Vidinis paskirstytasis CERT modelis. Igyvendinamos būdingos CERT tarnybai funkcijos per struktūras, kurios gali vykdyti ir kitus, nepriskirtus CERT, uždavinius.

3. Vidinis centralizuotas CERT modelis. Sukurta specialiai CERT funkcijoms vykdyti struktūra, kurios veiklos prioritetas - reagavimas $\mathfrak{i}$ saugumo incidentus.

4. Vidinis apjungtas paskirstyto ir centralizuoto CERT modelis. Derinamos dviejų ankstesnių CERT modelių savybès.

5. Koordinacinis CERT modelis. Toks modelis užtikrina incidentų tyrimus tarp keleto įmonių ar organizacijų ir gali apimti didelị regioną, kuriame gali būti ir kitų veikiančių CERT tarnybų.

Darbe (Wiik 2005) pateikiamas naujas metodas kaip pagerinti tradicinio incidentų tyrimų CERT modelio efektyvumą pasinaudojant dinaminio priartejjimo sistema. Daroma prielaida, kad praktikoje stebimas nuolat didejjantis incidentų kiekis, ko pasekoje CERT tarnybos, negalinčios adekvačiai padidinti turimų resursų, negali apdoroti visų incidentų laiku, nukenčia tyrimų kokybė. Ši CERT problema sprendžiama dinaminio priartejimo sistemos (DPS) pagalba, kuri turi pagerinti CERT efektyvumą. DPS plačiai naudojama ekonomikos, psichologijos bei inžinerijos moksluose ir yra paremta teorija, kad sistemoje su iejjimo ir išèjimo svoriais galima organizuoti grižtamaji ryši, kurị visada galima keisti taip, kad prie kintančio ịejjimo sistema visada liktų subalansuota. Tokiu būdu sistemos elgesys priklausys nuo grižtamujų ryšių. Atsižvelgiant i tai, autoriai išskaite CERT $\mathfrak{i}$ atskirus funkcinius mazgus, sudare jiems iejjimų ir išèjimų sistemą ir èmèsi sumodeliuoti ryšius tarp jų. Sudètingų ryšių sistema sudaryta taip, kad sistema galètu funkcionuoti optimaliai, t. y. incidentų tyrimas visada galètų vykti optimaliai. Aptartą modelį iliustruoja 1.1 paveikslas.

Darbe (Killcrece 2003) teigiama, kad didėjantị veikiančių CERT tarnybų skaičių lemia augantis saugumo incidentų mastas ir neišvengiamas poreikis ị tai reaguoti, teisiniai reikalavimai bei vyraujanti nuomone, jog saugumas IT sistemose turi būti siekiamas aktyviais veiksmais. Taip akcentuojama, kad saugumo incidentų valdymas tampa ženkliai efektyvesnis, kai be reagavimo ị incidentus, atliekamos ir prevencinès priemonès, tokios kaip savalaikiai ìspèjimai apie grèsmes, informavimas, incidentų detektavimo priemonès, sensoriai tinklo mazguose ir pan. Be to, šaltinis identifikuoja ir tam tikras spragas CERT srities dokumentuose: ženklus trūkumas saugumo incidentų 
tyrimų standartų; nevisiškai aiškus duomenų valdymo (saugojimo, archyvavimo, pasiekiamumo) klausimas.

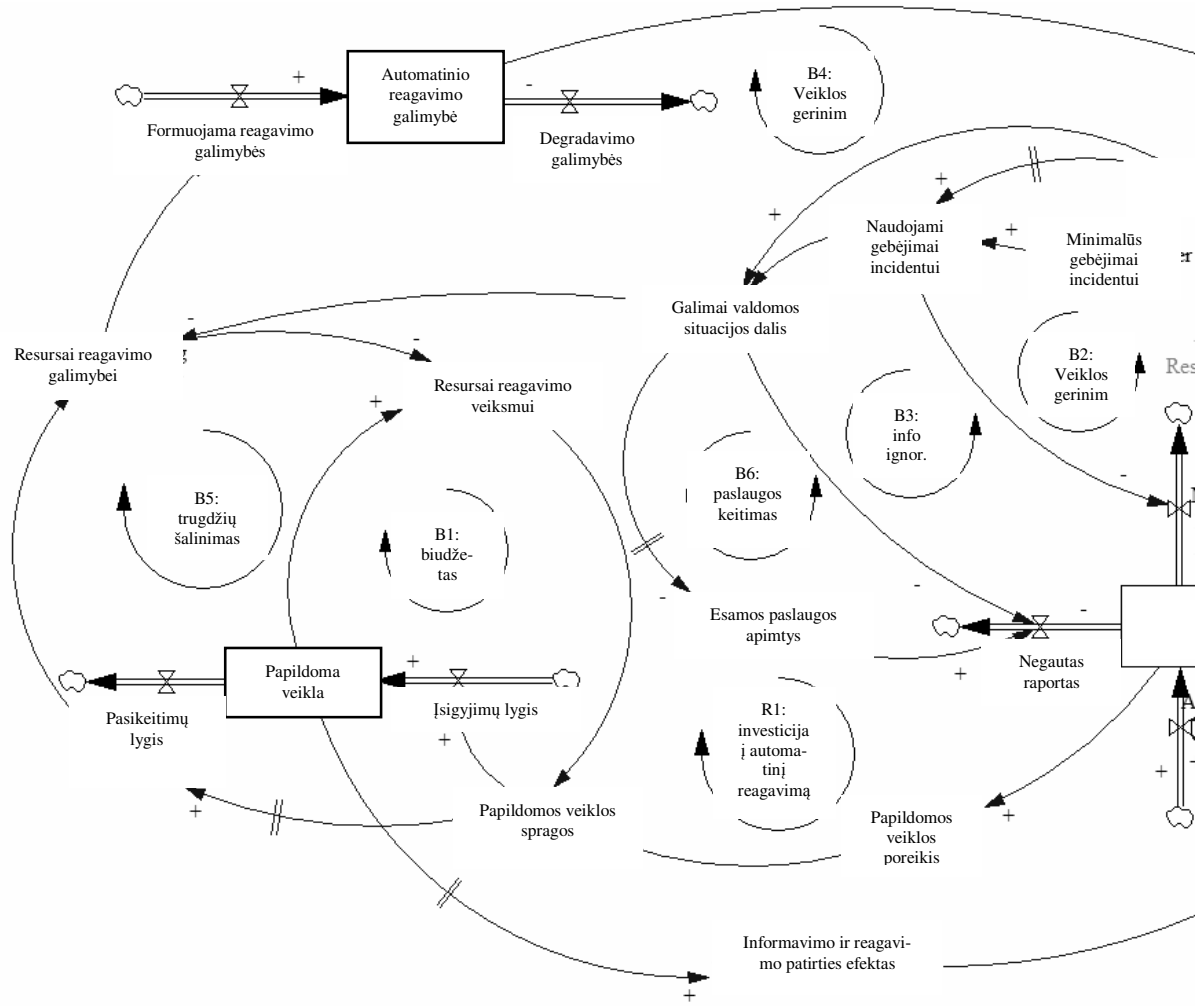

1.1 pav. DPS modelio schemos fragmentas (Wiik 2005)

Fig. 1.1. Fragment ofDPS model scheme

Bandymų rezultatais tvirtinama, kad reikšmingiausias (turintis didžiausią svorị) grižtamasis ryšys sistemoje yra automatizuoto reagavimo galimybės. Praktikoje autoriai siūlo, esant padidejjusiai incidentų tyrimo apimčiai, CERT tarnyboms laikinai riboti žemo prioriteto incidentų tyrimus, o atsilaisvinusius resursus nukreipti automatizuotoms reagavimo funkcijoms kurti. Autoriai taip pat akcentuoja prevencinių metodų naudojimą, kaip vieną efektyviausių incidentų mažinimo priemonių. Kalbama apie vartotojų mokymus, rekomendacijų leidimą, pažeidžiamumų testus ir pan.

Darbe (Karun 2006) ieškoma incidentų apdorojimo efektyvumo gerinimo būdų. Šio tikslo siekiama pasinaudojant Ford-Fulkerson grafų teorijos algoritmu. Nagrinèjamas grafas, paprastai susidedantis iš ištakos ir santakos tarp kurių yra eilè mazgų sujungtų ryšiais kryptimi nuo ištakos į santaką. Ford- 
Fulkerson algoritmas paremtas teorija, kad maksimalus kelių skaičius atitiks minimalų mazgų kirtimų skaičių. Mazgai yra CERT specialistai, vykdantys incidentų tyrimus, o ryšiai žymi informaciją apie incidentų srautus. Išskirti du vyraujantys CERT organizacinius modelius: hierarchinị ir matricos tipo. Vèliau, pasinaudodamas minètais grafų teorijos metodais, pritaiko juos CERT organizacijai ir incidentų tyrimo procesui modeliuoti bei jiems optimizuoti. Programiškai sukuriamas šiais algoritmais paremtas prototipas. Testų rezultatai parodè, kad matricos tipo organizacinis CERT modelis efektyvesnis nei hierarchinis. Kadangi incidentai kinta ir nèra vienodi, tokiu metodu metodo veikimo efektyvumas mažèja.

Saugumo incidentų ir pažeidžiamumų kompiuterinèse programose sąryšis nagrinejjamas darbe (Condon 2007). Egzistuoja tiesioginė priklausomybè tarp saugumo spragų (pažeidžiamumų) programose ir saugumo incidentų (virusų, ịsilaužimų ir pan.), t. y. pastarieji daugumoje plinta išnaudodami pažeidžiamumus. Daroma prielaida, kad ịmanoma sumažinti saugumo incidentų skaičių užtikrinant programų patikimumą. Irodinèjant šią prielaidą, buvo paimta didelis skaičius incidentų iš akademinio tinklo CERT tarnybos ir atliktas jų stebejjimas laikotarpiais informacinèse sistemose su saugumo spragomis programose ir vẻliau sistemose su pašalintais pažeidžiamais. Pokyčiams ịvertinti autoriai panaudojo Laplaso faktorių, skaičiuojamą pagal formulę:

$$
u(k)=\frac{\sum_{i=1}^{k}(i-1) n(i)-\frac{(k-1)}{2} \sum_{i=1}^{k} n(i)}{\sqrt{\frac{k^{2}-1}{12} \sum_{i=1}^{k} n(i)}} .
$$

kurioje $k$ yra stebejjimų laikotarpiai (dienos), o $i$ - incidentai. Laplaso faktoriaus kitimas parodè priklausomybę tarp incidentų ir saugumo spragų. Toliau siūloma taikyti ịvairius programų patikimumo gerinimo metodus. Pritaikius praktikoje, tai gali turèti teigiamos ịtakos incidentu prevencijai, bet tik kaip pagalbinè priemonè CERT sistemose, kadangi neịvertina daugelio incidentų tyrimų aspektų. Programų gamintojai ištaiso tik žinomas iš anksčiau saugumo spragas, be to visada egzistuoja „langas“ tarp saugumo incidento ịvykio ir momento kai gamintojas išleidžia saugumo pataisymus.

Kadangi privačiame sektoriuje dèl saugumo incidentų IS, elektroninèse paslaugose patiriami finansiniai nuostoliai incidentų tyrimai aktualūs įmonèms ir organizacijoms. Šioje srityje darbas (Masurkar 2003) yra nagrinejja incidentų tyrimų reikšmę bei ịvairius organizacinius CERT modelius. Išskiriami dedikuoti CERT, kurių incidentų tyrimai yra pagrindinè veikla ir nededikuotus CERT, kurie suformuojami tik tam momentui kai incidentu tyrimas yra būtinas. Nagrinejjami abiejų tipų galimos struktūros ir sudètis, kad pasiekti efektyvų 
CERT funkcionalumą bei didelis dèmesys skiriamas saugumo politikos organizacijoje nustatymui ir jos suderinimui su incidentų tyrimų procesu. Originali autorių siūloma CERT struktūra pavaizduota 1.2 paveiksle.

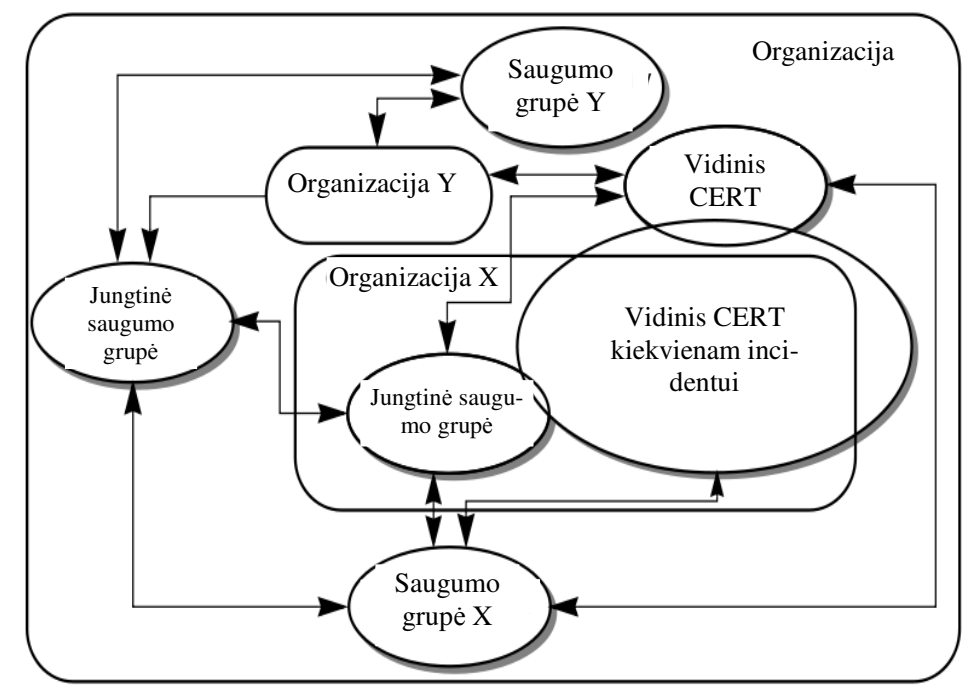

1.2 pav. Organizacinè CERT struktūra (Masurkar 2003)

Fig. 1.2. Structure of organisational CERT

Darbe (Hadgkiss 2006) apie CERT galimybių plètrą, nagrinèjama kaip incidentų tyrimus įtakoja CERT mokymo procesą. Tai yra akcentuojama, kad incidentų tyrimų rezultatai turètų būti peržiūrimi, analizuojami ir vèliau turi įtakoti viso CERT proceso tobulejimą (mokymą). Autorius pažymi, kad egzistavo trūkumas medžiagos, tiesiogiai susijusios su tinklų ir informacijos saugumo incidentų tyrimais ir CERT savęs mokymo proceso ypatumais, todèl buvo pasinaudota informacija apie metodus, naudojamus medicinos ir gynybos srityse. Kad patvirtinti savo hipotezes, autorius atliko tyrimą, kurio metu apklausė eilę ekspertų iš CERT tarnybų. Apibendrinant darbo rezultatus pateiktus šaltinyje (Hadgkiss 2006), 1.3 paveiksle pavaizduota autoriaus incidentų tyrimų schema, kurioje atvaizduojamas ir mokymas iš incidentų kaip atskira modelio dalis.

Kitas metodas saugumo incidentams tirti susijęs su kombinuotomis saugumo incidentu aptikimo programinemis priemonèmis (Ando 2007). Metodas paremtas dviejų tipų įsibrovimo aptikimo sistemų (IAS): anomalijų aptikimo IAS ir nesuderintu veiksmų detektavimo IAS lygiagretaus veikimo principu. Abi sistemos yra IAS atmainos, kuriose skiriasi veikimo principas 
aptinkant saugumo incidentą. Nesuderintų veiksmų detektavimo IAS veikimas paremtas žinomų informacinių sistemų pažeidžiamumų išnaudojimo scenarijaus duomenų baze, kai tuo tarpu anomalijų aptikimo IAS remiasi nenumatyto (neatitinkančio aprašyto scenarijaus) informacinès sistemos elgesio detektavimu. Pastebèta, kad nesuderintų veiksmų detektavimo IAS nesugeba aptikti incidentų kai panaudojamas naujai nustatytas saugumo pažeidžiamumas, nesantis IAS duomenų bazès įrašuose, o anomalijų aptikimo IAS praktikoje išduoda didelị skaičių neteisingų pavojaus signalų. Autoriai daro prielaidą, kad lygiagrečiai veikiančios nesuderintų veiksmų detektavimo IAS ir anomalijų aptikimo IAS gali efektyviau identifikuoti îspejjimus apie būsimus saugumo incidentus. Metodas ženkliai padeda korektiškam saugumo incidentų identifikavimui ir gali būti panaudotas, pavyzdžiui, kaip dalis CERT modelio, tačiau praktiškai neįtakoja incidentų tyrimo.

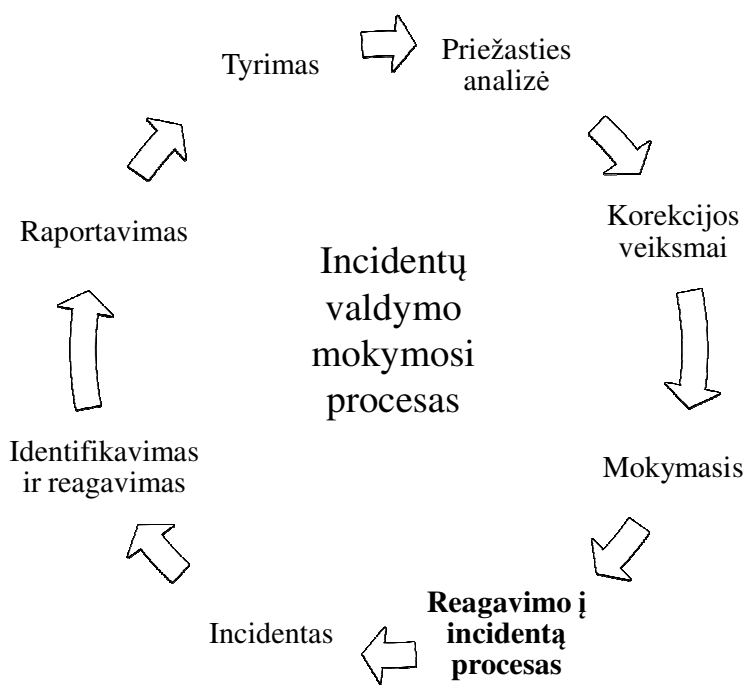

1.3 pav. Mokymo proceso incidentu tyrimo procese schema

Fig. 1.3. Education process influence to incidents management

\subsection{Apibendrintasis CERT modelis}

Pagal CERT modelį, saugumo incidentų valdymas vyksta trimis pagrindiniais etapais:

- pranešimų apie incidentus prièmimas, ̣̂vertinimas ir pradinis prioriteto priskyrimas (rūšiavimas); 
- incidentų tyrimas ir techninis apdorojimas bei tikslinių vartotojų grupių informavimas apie grèsmes;

- reagavimas $\mathfrak{i}$ incidentus, statistinis registravimas, incidentų plitimo užkardymas, tinklo ar IT veiklos atstatymas.

Veikiančiame CERT tarp šių trijų darbinių etapų (funkcinių objektų) egzistuoja tarpusavio ryšiai (1.2 pav.). Raudonai pažymètos kryptys yra bazinès, šiuo keliu vyksta pagrindinis darbas su informacija apie incidentą. Svarbų vaidmenị vaidina išankstinio ịspejjimo sistema, t.y. prevencinė priemonè, skirta informuoti tikslines grupes (vartotojus, tinklų administratorius, kitus CERT), siekiant užkirsti kelią tolesniam incidento plitimui.

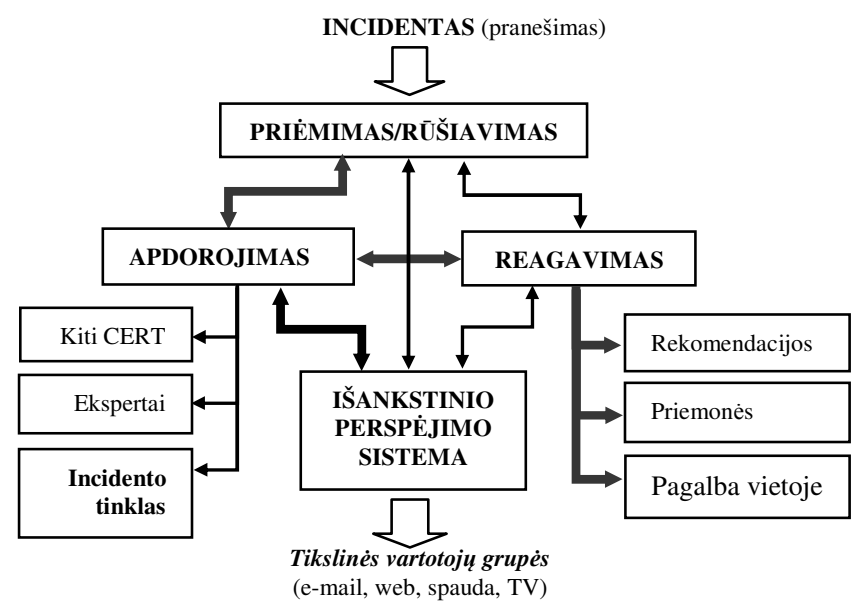

1.4 pav. Funkcinè CERT veiklos schema

Fig. 1.4. CERT model functional scheme

CERT veikimo modelyje pagrindinis apdorojamasis objektas yra pats saugumo incidentas. Dėl CERT modelio specifikos, egzistuoja didelis skaičius variantų kokiu keliu vyksta incidento tyrimas. Toliau siekiama, pritaikant klasikinio CERT modelio pagrindus (West-Brown 2003), sukurti individualų, priimtiną situacijai Lietuvos interneto tinkluose, incidentų valdymo metodą.

Informacija apie incidentą, patekusi į CERT, pereina apdorojimo CERT sistemoje ciklą (1.3 pav.):

1. Visu pirma priimamas pranešimas apie saugumo incidentą. Tai gali būti padaryta elektroniniu paštu, telefonu, per specialią internetinès svetainės formą. Toks veiksmas paprastai atliekamas interneto vartotojo, kuris turi informacijos apie konkretų saugumo incidentą. Ilgą laiką CERT modelyje tai buvo pagrindinis pranešimo apie incidentą šaltinis. Laike kibernetinès atakos ir kenksmingas 
programinis kodas keitėsi. Dabar virusų veikla dažniausiai užslëpta kompiuterio operacijų procesuose (Ferrie 2004), o kompiuteriai pakankamai našūs, kad dèl viruso veiklos procesai vizualiai nesulètètų. Kibernetinès atakos, kuriomis nesiekiama pažeisti tinklo infrastruktūros, atliekamos informacijos vagystės tikslu, todèl paprastai jos yra maskuojamos. Dèl šių priežasčių, kyla poreikis pranešimus apie incidentus generuoti automatinėmis programinèmis priemonėmis. Tai atliekama per ịsibrovimų aptikimo sistemos (IDS) signalus ar naudojant tinklo sensorius. Konfidenciali informacija siunčiama naudojant elektroninio parašo (asimetrinès kriptografijos) technologiją. Priimtas pranešimas užregistruojamas su incidentų valdymo programa, suteikiančia incidentui individualų identifikacinị numerị, lydintị ji per visą procesą iki incidento uždarymo.

2. Ivertinamas incidento pavojaus saugumui lygis, t.y. priskiriama saugumo kategorija. İvertinant atsižvelgiama į:

a) atakos daromą destrukcinị poveikị (ar tai tik komercinis spam, ar tai virusas, keičiantis bylų struktūras.);

b) pažeistos kompiuterinès sistemos svarbą (ar atakuojama tarnybinè stotis, kuri teikia paslaugą daugeliui klientų, ar periferinis tinklo įrenginys);

c) incidento plitimo mastą (kaip sparčiai incidentas plinta, ar incidentas vis dar tęsiasi). Nuo priskirtos kategorijos priklauso CERT reagavimo laikas. Aukščiausios kategorijos incidentas turètų būti sprendžiamas ne eilès tvarka.

3. Toliau atliekami prevenciniai veiksmai. Jeigu incidentas vyksta tyrimo metu, nèra galimybès jo sustabdyti lokaliai ir yra pavojus kitiems vartotojams blokuojamas incidento šaltinio IP adresas arba stengiamasi išardyti botnet tinklą ir pan. Jeigu incidentas pavojingas ir yra tolesnių pažeidimų rizika, rengiamas ispejjimas tinklo naudotojams ir kitoms CERT grupèms.

4. Po šių veiksmų CERT tarnybos personalas su specializuota techninė bei programine ịranga atlieka incidento turinio ir incidentą lydèjusios aplinkos analizę, statistinių duomenų rinkimą bei apsaugos priemonių kūrimą. Tai yra veiksmų (1.5 pav.) vykdymo ciklas:

a) Incidento analizè - pagrindinis ir daugiausiai laiko užimantis CERT veiksmas. Analizuojami po incidento likę artefaktai (angl. log file), patys incidentai (pavyzdžiui, kenksmingas programinis kodas), techninè ir (arba) programinè įranga, kurios aplinkoje įvyko incidentas. Kiekviena operacinè sistema (o ypač ta, kuri yra/veikia tarnybinèse stotyse) turi priemones, fiksuojančias sistemos darbo klaidas ir saugančias jas specialiuose (log) archyvuose. Log file nagrinèjimas dažniausiai tampa pagrindiniu analizès objektu, nes gali pasakyti, kokios konfigūracijos sistemoje ir kada ịvykis buvo užfiksuotas, kokių procesų veikimas sistemoje sutriko ir kt. Tuo atveju, kai incidentas pats plinta kaip atskiras procesas tinkle (pavyzdžiui, kompiuterinis virusas), reikia jị tirti atskirai. Čia padeda virtualios, izoliuotos kompiuterio aplinkos sukūrimas, kurioje paleidus veikti virusą specialios programos stebi ir fiksuoja viruso sistemoje padarytus 
pakeitimus. Kontrolinė suma gali parodyti buvusius pasikeitimus. Iš to sprendžiama apie padaromą žalą bei numatomi apsisaugojimo variantai.

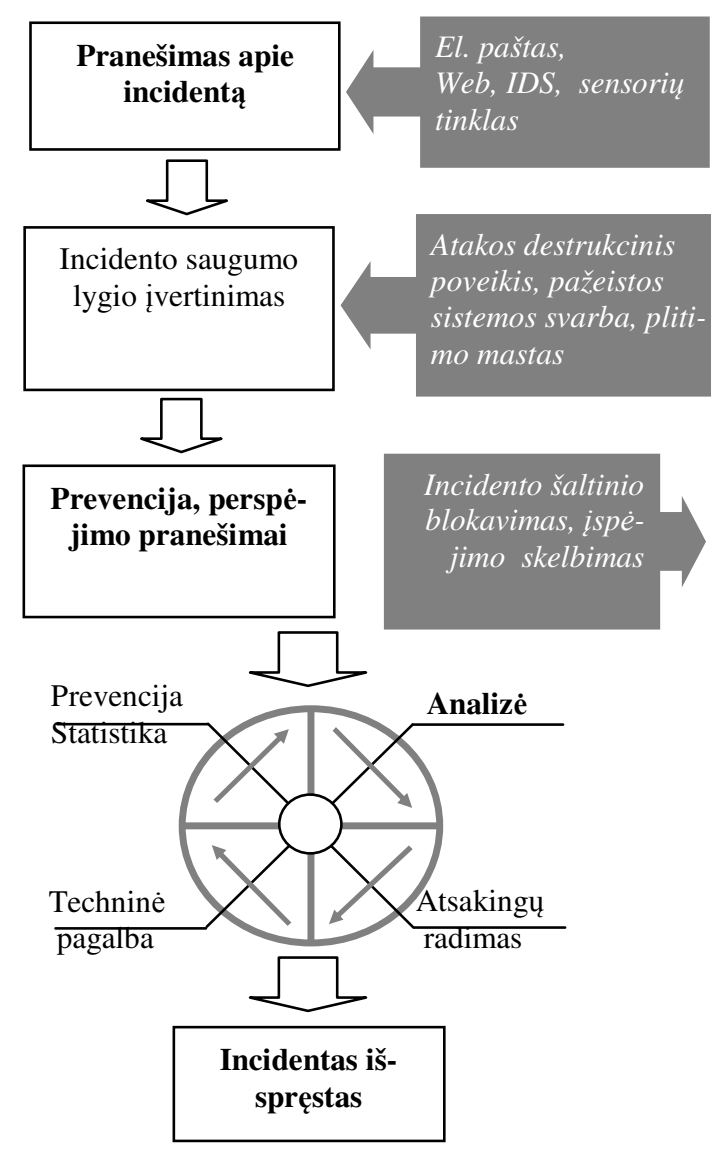

1.5 pav. Saugumo incidento gyvavimo ciklas

Fig. 1.5. security incidents life cycle

b) Atlikus visapusišką incidento analizę, pereinama prie atsakingų už incidentą asmenų paieškos. Todėl nagrinėjamas incidento šaltinio IP adresas. Per vidines ir išorines (pavyzdžiui, tarptautinę ,,whois“ sistemą) duomenų bazes surandama, kas atsakingas už incidentą, jeigu reikia, incidento iniciatorius ịspèjamas stabdyti incidentą arba, jeigu incidentas yra iš kitos šalies, informuojamas tame tinkle veikiantis CERT. Kita vertus, būtina aiškiai žinoti pranešèjo apie incidentą koordinates, kad būtų galima gauti papildomai informacijos, jei analizei jos pritrūktų. 
c) Jeigu incidentas toliau plinta ị kitus tinklo ịrenginius, reikia kuo greičiau sukurti apsaugos priemones ir jas ịdiegti, kad galima žala būtų minimali. Jeigu incidentas neplinta, tačiau yra padarytas destrukcinis poveikis sistemoms, CERT tarnyba imasi veiksmų, kurdama atitinkamas rekomendacijas ar techninius įrankius, kurie galètų atstatyti sistemą i pirminę būseną.

d) Toliau surinkta informacija gali būti perduota teisèsaugos institucijoms, jeigu pagal įstatymus už incidento sukèlimą yra numatyta administracinė ar baudžiamoji atsakomybè. Bet kuriuo atveju, incidentas yra statistiškai fiksuojamas, kad būtų nuolat stebimos bendrosios vienų ar kitų incidentų raidos tendencijos.

5. Jeigu iki šio momento atlikti veiksmai nedavė rezultatu - incidento priežastys neišaiškintos, plitimas nesustabdytas, neatstatyti sugriauti tinklo ar sistemos segmentai - incidento nagrinejjimas grąžinamas ị analizès stadiją. Kitu atveju incidentas laikomas išspręstu ir yra atliekamas įrašas incidentų valdymo sistemoje apie tyrimų pabaigą.

Išdèstyti incidento apdorojimo ir tyrimo pagal CERT modelị etapai iš esmès yra reakcinio pobūdžio. Teigiama, kad CERT modelis turi neapsiriboti aktyviais incidentų tyrimų veiksmais (West-Brown 2003). CERT modelyje siūloma ịvedama incidentų prevencija, kuri ịgyvendinama išankstinio perspejimo sistemos (IPS) pagalba (1.4 ir 1.5 pav.). IPS tampa reikšminga priemone, nes yra skirta veiksmams mažinantiems arba neutralizuojantiems incidento poveikị IT.

IPS pagrindą sudaro informacijos apie incidentą surinkimo sensoriai. Tai gali būti ịsiskverbimo detektavimo sistemos (IDS), kurios pagal tipines programinio kodo signatūras atpažįsta veiksmus, būdingus ịsibrovimui ị IT. Arba „medaus puodynès“ (honeypot) pagrindu veikiantys agentai (programinio kodo intarpai) tinklo mazguose sekantys kompiuterinių virusų aktyvumą ir registruojantys iš kontrolerių jiems siunčiamas komandas (Provos 2007). Analizuojant IDS ir honeypot informaciją ịvertinama rizika ịvykti incidentui ir atitinkamai formuojamas perspejimas IT valdytojams.

\subsection{Tyrimai Lietuvoje}

Lietuvos universitetuose formuojama praktika vykdant tyrimus kibernetinio saugumo srityje. Vilniaus Gedimino Technikos Universitete (VGTU) veikia Informacinių technologijų saugos mokslo laboratorija. Vadovaujant prof. A. Čeniui tyrimai apima kibernetinių atakų (kenksmingo kodo propagavimo, botnet, PAAA) detektavimą ir analizę. Taip pat atliekami apsaugos priemonių (IDS, honeypot) analizès ir jų tobulinimo darbai. Kauno technologijos universitetas tiesiogiai dirba su CERT modeliu, kuris yra praktiškai pritaikytas akademinio tinklo saugumo incidentų tyrimuose, o CERT modelis tobulinamas. Prof. A. Kajackas (VGTU) vadovauja interneto tinklo patikimumo ir paslaugų kokybès ty- 
rimams, prof. J. Skudutis (VGTU) darbo veikla susijusi su apsaugos nuo kibernetinių atakų priemonių analize ir IT sistemų išliekamumo tyrimais.

\subsection{CERT modelio trūkumai}

CERT modelio, kuris trumpai gali būti apibūdinamas kaip aptikimo-pašalinimoatstatymo organizacine sistema, naudojimas yra grynai reaktyvus, t. y. vyksta veiksmas pagal faktą. Iš to darytina išvada, kad CERT efektas yra trumpalaikis sprendžiamas konkretus incidentas ir reaguojama į jo pasekmes. Dažnai incidento šaltinis nèra nustatomas, nes pagrindiniu CERT tikslu yra sustabdyti incidento plitimą ir atstatyti pažeistas IT ar teikiamas paslaugas. CERT išsprendus incidentą, kibernetinių atakų šaltinis(iai) gali atlikti pakartotinas atakas išnaudodamas kitus tinklo ar IT pažeidžiamumus. Pastebètina, kad CERT nèra veiksni priemone sistemiškai spręsti interneto saugumo ir patikimumo uždavinio. Interneto patikimumo uždavinys yra labiau susijęs su tinklo sistemų ir procesų ịvertinimu.

\subsection{Interneto patikimumo prigimtis}

Inžinerijoje patikimumo klausimas plačiai nagrinejjamas ir taikomas, kai sistemos bei mechanizmai projektuojami išlikti funkcionaliais nepalankių sąlygų aplinkoje (Smith 2005). Patikimumas susijęs su mechanizmo rezervo projektavimu, kuri siekiama sudaryti didesnį nei yra reikalinga veikti normaliomis sąlygomis. Tradicinèje inžinerijoje patikimumas yra medžiagos gebejjimas absorbuoti energiją esant spaudimui (arba ịtempimui) ir vèliau ją atiduoti.

Modernioms sistemoms patikimumas reiškia gebejjimą atlaikyti gedimus ir pajègumą pilnai atstatyti funkcionalumą. Bendraja prasme (pavyzdžiui, biologijos moksle) tai yra sistemos gebejjimas išgyventi grèsmių akivaizdoje. Arba sistemos gebejjimas adaptuotis besikeičiančioms aplinkos sąlygoms (Wagner 2008). Ivykiai gali turèti įtakos sistemos darbui, bet patikima sistema turi sugebèti išlikti pajègia veikti tam tikru priimtinu lygiu ir gebèti laiko bègyje pilnai atstatyti savo veiklą.

Interneto atveju, patikimumas vertintinas makro ir mikro lygiais (Hall 2011). Didelio junglumo tinkle vieno maršrutizatoriaus gedimas paprastai susijęs su ryšio netekimu vartotojams trumpam laikotarpiui (arba jis nejuntamas visiškai), kai duomenų srautai momentiškai perskirstomi kitais maršrutais (mikro lygmuo). Makro lygmeniu didelio masto kibernetinès atakos, epideminis kenksmingo programinio kodo plitimas ar gamtos stichinès nelaimès gali sukelti gedimus eilèje tinklo grandžių, dèl ko interneto paslaugos sutrikimas juntamas didesniam vartotojų skaičiui ir ilgesni laikotarpị. Todèl išskiriami sekantys interneto patikimumo požymiai pagal poveikị: tinklo gebejjimas akumuliuoti pa- 
vienių elementų gedimus ir gebėti toliau teikti duomenų perdavimo paslaugas; tinklo gebejjimas atstatyti tinklo junglumą (duomenų perdavimo paslaugas) iki pirminio lygio per priimtiną laiko tarpą po reikšmingo tinklo grandžių (potinklių) gedimo.

Interneto tinklo patikimumo metrika nèra galutinai parengta. Mokslo tiriamuose darbuose nepakankamai apibyrèta interneto patikimumo charakteristika, priimtinas interneto paslaugos lygis. Interneto tarptinklinių sujungimų kompleksiškumas ir ribota informacija apie pilną interneto topologiją, sudaro sunkumus vertinant interneto patikimumą. Nèra prielaidų interneto patikimumą išreikšti skaitine verte. Praktiškai sudètinga ịvertinti kokią realią įtaką tinklui turès incidentas ar gedimų įvykis.

\subsection{Pirmojo skyriaus išvados ir disertacijos uždavinių formulavimas}

Internetas yra vienas labiausiai išvystytų IRT tinklų, kartu ir dažniausia pažeidžiamas dèl kibernetinių atakų ir tinklo infrastruktūros grandžių gedimų. CERT modelio vaidmuo siekiant saugumo incidentų valdymo Internete įrodytas kitų autorių bei šio darbo rèmuose. CERT modelis leidžia operatyviai valdyti saugumo incidentus tinkle bei sudaro prielaidas internetui ir IT išlikti efektyviai veikiančiomis sistemomis.

CERT modelis būdamas efektyvus incidentų tyrimuose ir reagavimo metoduose, nesudaro reikiamų prielaidų bendram interneto tinklo saugumo ir patikimumo vertinimo klausimui spręsti. Kyla poreikis pasirinkti ir vystyti naujas, pro-aktyvias (prevencines) priemones, kurios sudarytų sąlygas mažinti interneto pažeidžiamumą ar neutralizuoti kibernetinių incidentų ịtaką internetui.

Toliau formuluojamas uždavinys, suponuoja interneto saugumo analizès klausimą spręsti tyrinèjant pačią interneto tinklo infrastruktūrą. Didelio masto kibernetinès atakos bei pagrindinès interneto TCP/IP ir tinklų maršrutizacijos protokolas (BGP) protokolu saugumo problemos demonstruoja realias grèsmes interneto veiklos patikimumui. Iš to kyla darbo tikslas: tirti ir analizuoti stochastiškai sujungtų potinklių susiformavusị regiono ar valstybės interneto tinklą kaip bendrą sistemą, ir ieškoti būdų, kaip nustatyti ir stebèti tokios sistemos infrastruktūros vientisumo, veiklos nenutrūkstamumo bei patikimumo kokybės palaikymo rodiklius.

Tikslui pasiekti reikia spręsti uždavinius:

1. Ivertinti interneto tinklo topologijos schemą bei sudaryti jos analizès modelius ir priemones.

2. Ivertinus topologiją, tolimesni tyrimus orientuoti į interneto tinklo junglumo analizę, siekiant identifikuoti kritinius tinklo elementus, kurių pažeidimai susiję su viso tinklo funkcionalumo praradimu. 
3. Turint nustatytus kritinius interneto tinklo elementus, toliau sudaromas modelis jų stebėsenai, atliekami kibernetinių atakų simuliacijos eksperimentiniai bandymai.

4. Reziumuojant, tyrimais gauti rezultatai sudaro prielaidas formuluoti priemones interneto tinklo infrastruktūros patikimui stiprinti, kurios savo ruožtu formuoja regiono interneto ateities reguliavimo ir vystymo gaires. 


\section{2}

\section{Interneto tinklo infrastruktūros topologijos tyrimai}

Skyriuje analizuojamas iš stochastiškai sujungtų potinklių susiformavęs valstybès ar regiono interneto tinklas kaip bendra sistema, ir ieškoma būdų, kaip nustatyti tokios sistemos patikimumo, veiklos nenutrūkstamumo bei paslaugų kokybès palaikymo rodiklius. Analizuojant tinklo topologiją, pasiūlytas AS ir jų sujungimo liniju klasifikavimas bei parinkta naudoti grafų metriką su mazgų laipsniais ir jų pasiskirstymais. Taikyta metrikai regiono interneto tinklo infrastruktūrai atskleide, kad regiono tinklas, vertinant AS ir jų sujungimus, yra neproporcingai segmentuotas, todèl egzistuoja pažeidžiamumai, kurie turi įtakos tinklo veiklos patikimumui.

Skyriaus tematika paskelbtas vienas autoriaus straipsnis (Kajackas, Rainys 2010).

\subsection{Interneto tinklo specifika}

Elektroniniai ryšiai ir internetas vaidina ypatingai svarbų vaidmenį šių dienų visuomenès gyvenime. Gerai žinoma, kad internetas yra informacinès visuomenès pagrindas, Jungtinių Tautų Organizacija 2011 metais pripažinto teisę i prieigą prie interneto viena iš pamatinių žmogaus teisių. 
Techniškai interneto pagrindą lemia TCP/IP protokolas, palaikantis paskirstytą (decentralizuotą) sąveikaujančių komunikacijų priemonių sistemą ir sudarantis galimybę perduoti bei priimti bet kokios prigimties ir rūšies elektroninę informaciją. Technologinès ir funkcinès interneto galimybès sudaro neribotas galimybes tinklo plètrai, laisvą naujų mazgų ir potinklių prisijungimą. Šiuo metu veikia daug interneto prieigos ir paslaugų teikejjų (IPT), kurių skaičius nuolat auga. Jie kuria naujus lokalius potinklius ir naujas paslaugas, pritraukia nauju vartotojų.

Interneto plètrai esminę įtaką daro naujos technologinès galimybès, naujos paslaugos, nuolat didejantis vartotojų skaičius, augantys vartotojų sukuriamų duomenų srautai. Kartu su interneto plètra auga ir jo atsakomybè, reikalavimai patikimumui, gyvybingumui bei duomenų saugumui. Todèl šiuolaikinis internetas yra nuolatinių mokslinių tyrimų objektas.

Analizuojant atskirų regionų ir valstybių interneto tinklų evoliuciją, pastebima bendra tendencija - kiekvienas IPT kuria savo tinklą. Dẻl to interneto tinklų infrastruktūra susiformuoja stochastiškai, be sistemingo regiono tinklo projekto, be išsamios duomenų srautų bei pralaidumų analizès. Galima sakyti, kad regiono interneto tinklą sudaro atsitiktinai sujungti potinkliai. Todẻl nėra žinoma ar pakankami tinklo mazgų bei jungiamujų kanalų pralaidumai, ar tie pralaidumai bus pakankami esant atskirų mazgų bei kanalų gedimams, ar jie bus pakankami atsitiktinai padidejjus duomenų srautams ar kibernetinių atakų atvejais.

Disertacijos apimtyje vykdoma tiriamojo darbo kryptis - tirti ir analizuoti stochastiškai sujungtų potinklių susiformavusị regiono ar valstybės interneto tinklą kaip bendrą sistemą, ir ieškoti būdų, kaip nustatyti tokios sistemos patikimumo, veiklos nenutrūkstamumo bei paslaugų kokybès palaikymo rodiklius. Siekiant įvardintų tikslų šiame skyriuje sprendžiami uždaviniai: susiformavusios interneto tinklo topologinès schemos sudarymas, modelių ir analizès priemonių parinkimas.

Šiame skyriuje bus parodytą, kad interneto veiklos patikimumas, kitaip tariant tinklo išliekamumas, priklauso nuo tinklo topologijos. Tuo tarpu topologija yra tiesiogiai veikiama kibernetinių atakų, gedimų tinklo infrastruktūroje ir t. t. Detalus topologijos ịvertinimas gali padeti nustatyti silpnąsias tinklo vietas ir suprasti kaip pasiekti didesnị interneto patikimumą.

\subsection{Interneto tinklo modelis}

Interneto tinklo analizei atlikti, kaip išeities praktika remtasi egzistuojančių tinklų vertinimo darbais: elektros tinklai (Stubna 2002, Watts 1998), socialiniai ryšiai (Barabási 1999, Ball 2002) ar mitybos grandinès (Montoya 2002). Šių sistemų sąryšių mechanizmo supratimas padeda geriau suvokti ir analizuoti interneto tinklą. Tačiau bendraja prasme interneto tinklo modeliavimas, jo topo- 
logijos ir išliekamumo vertinimas, yra besiformuojanti mokslinè sritis (Chen 2002, Dimitropoulos 2006, Barabasi 2002, Magoni 2002, Medina 2000).

Vertinant literatūrą (Erdos 1960) apie atsitiktinių grafų charakteristikas, prie tokių priskirtinas ir internetas. Tokiu grafų analitinis nagrinèjimas įdomus subgrafų junglumo analize bendrame grafe. Tai yra paralelè ị interneto tinklą, kuris taip pat yra tinklas iš sujungtų lokalių potinklių. Teigiama, kad $N$ mazgų grafe bendras tikètinas briaunu skaičius yra lygus $p N(N-1) / 2$ (Erdos 1960). Kitas Erdos atradimas teigia, kad grafe su dideliu skaičiumi mazgų, briaunų prijungtų prie mazgo skaičiaus pasiskirstymas atitinka Puasono skirstinị. Tačiau ši prielaida daugeliui realių interneto potinklių topologijų pasirodė negaliojanti (Barabasi 1999).

Apibendrinto tinklo modelio pateikime, 2.1 pav., tinklo junglumas kinta nuo tinklelio formos $(2.1$ a) iki visiškai atsitiktinio $(2.1$ c). Tarp šių ekstremumų internetas atitinka tarpinị variantą $(2.1 \mathrm{c})$. Čia $p$ žymi tikimybę, kad kiekvienos briaunos galas per viršūnę gali turèti sujungimą su kita briauna (Albert 2002).

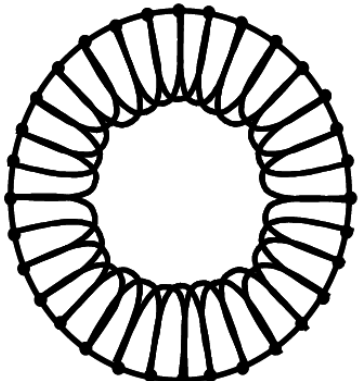

a)

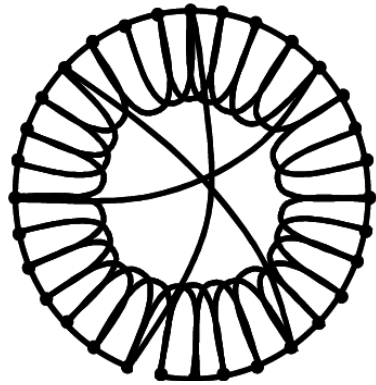

b)

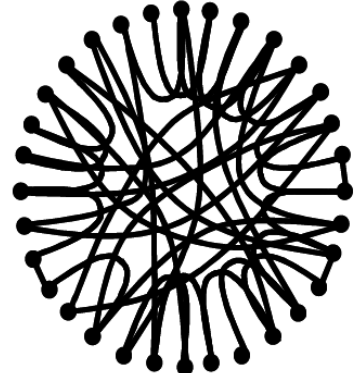

c)

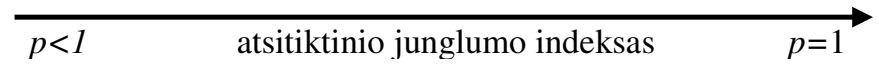

2.1 pav. Bendrinis tinklo junglumo modelis: a) tinklelio formos; b) tarpinis; c) atsitiktinis (Albert 2002)

Fig. 2.1. Simple network connectivity model: a) grid; b) interim; c) random

Nors internetas greitai plečiasi, prijungiami nauji mazgai ir potinkliai, tinklo modelis išlieka nepakitęs - tarp dviejų mazgų išlaikomas sąlyginai nedidelis atstumas (Albert 2002). Distancija tarp dviejų mazgų, tai mažiausias skaičius briaunų nusakančių trumpiausią atstumas tarp šių mazgų.

Interneto tinklo infrastruktūra kaip grafas nagrinèta eilèje darbų (Dimitropoulos 2006, Chang 2004, Dohoon 2008, Dolev 2006). Egzistuoja dvejopa interneto tinklo pateikimo praktika:

a) kai tinklo mazgus atitinka maršrutizatoriai, o linijas fiziniai sujungimai $\operatorname{tarp}$ jų; 
b) kai tinklo mazgus atitinka interneto autonominès sistemos (šios vidiniame potinklyje gali turèti ir daugiau nei vieną maršrutizatorių ar komutatorių), o linijas egzistuojantys sujungimai tarp jų.

Kadangi pastaruoju metu visuotine kompiuterizacija ir interneto kompleksiškumas ženkliai išaugo, išsiplètusiam tinklui dažniau pritaikomas modelis interneto atvaizdavimas kaip tinklo, sudaryto iš tankiai tarpusavyje sujungtu autonominių sistemu (AS). Interneto aplinkoje AS yra interneto protokolo (IP) maršrutizavimo adresų rinkinys, valdomas vieno ar kelių tinklo operatorių, skirtas standartizuotam ir viešam duomenu maršrutizavimui tinkle (Hawkinson 1996).

Teoriniuose darbuose (Gao 2000, Dimitropoulos 2006, Oliveira 2010) tinklo mazgais laikomos AS. Taip yra todèl, kad realiame tinkle ryšiams tarp atskirų potinklių valdyti naudojamas tinklų maršrutizacijos protokolas (BGP) protokolas (Rekhter 2006), kuris dinamiškoms sujungimų lentelèms sudarinèti panaudoja AS su tik jam priskirtu unikaliu numeriu. Iš to seka, kad AS vaidina pagrindinị vaidmenį duomenų srautų maršrutizavimui interneto tinkle. Realioje AS turi būti bent vienas mazgas, atliekantis tarptinklinius sujungimus.

\subsubsection{Topologija kaip multigrafas}

Ivertinus, kad iš atskirų AS sudaromas abstraktus interneto tinklo modelis yra paplitęs mokslinių tyrimų objektas, šiuo modeliu kaip pamatiniu elementu bus pasiremta siekiant šio darbo tikslų. Interneto tinklo fragmento, sudaryto iš tarpusavyje sujungtų AS, modelis supaprastintai atvaizduotas 2.2 paveiksle.

Tolesnei analizei kiekviena $\mathrm{AS}_{i}$ formaliai aprašoma grafu $G_{i}(V, U)$, sudarytu iš viršūnių $V$ ir briaunų $U$ aibių. Čia viršūnès atitinka realių AS mazgus, briaunos - atitinka jungiamąsias ryšių linijas. Pagal tinklo struktūrą nustatomi pradiniai nagrinèjamo tinklo ar $\mathrm{AS}_{i}$ duomenys: $N_{i}$ - mazgų skaičius, $M_{i}-$ briaunų skaičius.

Sudėtingą grafą galima išskaidyti ị paprastesnių grafų aibę. Paprasčiausia AS, kurioje yra vienas mazgas, atvaizduojamas grafu su viena viršūne. Atvirkščiai, apjungiant keletą AS su jas apibūdinančiais grafais gaunama sudètingesnè AS ir sudetingesnis grafas. Tokiu būdu apibendrinant viso regioninio tinklo infrastruktūra gali būti pateikiama kaip multigrafas $G_{\text {net }}$ arba kaip grafų $\left\{G_{i}(V, U)\right\}_{i=1}^{I}$ visuma.

Su grafais taip pat gali būti atliekami veiksmai kaip viršūnių šalinimas ar briaunos nutraukimas, kurie naudingi tinklo junglumo analizei. Taip pat galima analizuoti grafą nagrinejjant trumpiausią, greičiausią ir t. t. maršrutus (2.2 pav.). 


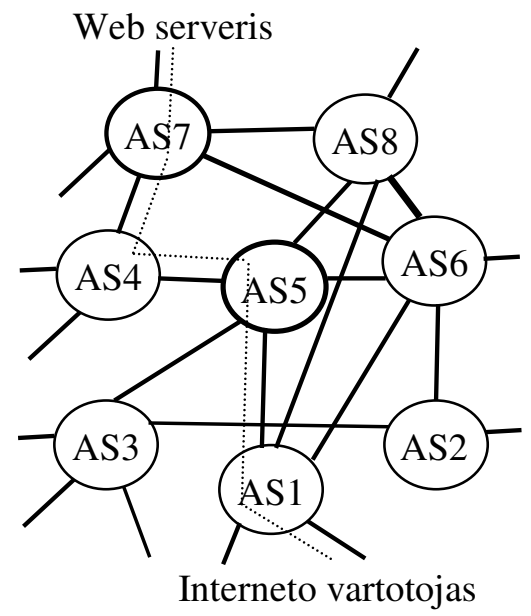

2.2 pav. Interneto autonominių sistemų tinklo topologijos fragmentas

Fig. 2.2. Internet autonomous systems network topology fragment

Bendrinis interneto, kaip tinklo, sudaryto iš ịvairaus sudètingumo AS, modelis, yra patogus tuo, kad analizuojant makro lygmens charakteristikas dažnai nereikia nagrinèti pilnas visu AS tipologines schemas, o galima apsiriboti tam tikrais išoriniais AS parametrais. Kaip rodo susijusių (Dolev 2006, Dimitropoulos 2009) darbu praktika nagrinèjant tinklo veiklos patikimumą, galimas fragmentiškas tam tikrų interneto AS nagrinèjimas, išskiriant struktūrinius vienetus apribotus geografiškai, ar priskiriamus konkrečiai organizacijai.

\subsubsection{Topologijos analizès principai}

Tiriama interneto tinklo infrastruktūra vertinant visus interneto potinklius, apribotus IP adresų ruožu, priskirtu Lietuvos valstybeje veikiantiems subjektams. Lietuvoje interneto prieigą teikia apie 110 gana skirtingo dydžio IPT. Dalis IPT duomenų maršrutizavimą tinkle organizuoja formuojant AS, tuo tarpu kita dalis, dažniausiai tai nedideli IPT, neturi AS. Tokie IPT jungiasi prie stambesnių IPT viena ryšio linija pirkdami ryšio paslaugą iš stambesnių IPT. Tokie IPT, turèdami tik po vieną (kartais kelias) jungti i i interneto tinklą, ịtakos bendram interneto tinklo infrastruktūros modelio junglumui neturi (Dolev 2006, Dimitropoulos 2009), nes tokie IPT neturi savybės tranzininio duomenų perdavimo.

Tobulinant ir patikslinant bendrą regiono tinklo modelį, jị būtina patikslinti atspindint esamą interneto hierarchinę struktūrą, išryškinant atskirų posistemių svarbą bei ịtaką. Interneto hierarchinè struktūra dažnai apibūdinama trijų tipų tinklo mazgais (SUNA 2004, Subramanian 2002): 
Tranzitinė AS. Turi daugiau nei vieną jungtị su kitomis AS ir didžiaja dalimi yra naudojama kaip tranzitinis mazgas duomenų srautams tarp kitų AS. Dauguma didžiųjų IPT yra Tranzitinès AS. Tranzitinis duomenų srautų perdavimas yra tokių AS verslo pagrindas. Šio tipo AS akumuliuoja didžiają dalị interneto srauto, todèl jos reikšme tinklo topologijoje yra išskirtinè.

Vartotojiška AS. Turi jungtị tik su viena kita AS. Žiūrint iš maršrutizavimo perspektyvos, Vartotojiška AS išplečia kitos AS, iš kurios perka tranzitinio duomenų perdavimo paslaugą, tinklą. Vartotojiška AS nepersiunčia kitų AS duomenų srautų ir jai reikalinga Tranzitinès AS išèjimams ị tarptautinị internetą. Praktikoje, lokalūs tinklai turintys vieną ryšio liniją su interneto tinklu, AS neformuoja ir jų IP adresacija Internete siejama su motinine AS, t. y. Tranzitine AS. Mūsų nagrinėjamu atveju tokio tipo potinklius atitiks nedideli IPT.

Kartotinė AS. Turi daugiau nei vieną jungti su kitomis AS. Tokios AS bruožas yra padidintas maršrutizavimo patikimumas kai panaudojama sujungimų dubliavimo technika. Taip pat gali būti sudubliuota pati AS. Dažnai naudojama didelèse organizacijose su kartotinèmis interneto jungtimis. Tokios organizacijos nebūtinai yra IPT ir jos neparduoda duomenų srauto kitoms AS. Tačiau tokioms organizacijoms, kaip bankai ar žiniasklaida, reikalinga sava ryšių maršrutizavimo prioretizacija bei išskirtinis ryšių patikimumas.

Paskirstytoji AS. Tokios AS duomenų bazès (serveriai) paskirstytos skirtingose regiono tinklo topologijos vietose. Tai atliekama siekiant geresnio AS pasiekiamumo ir patikimumo užtikrinimo. Tokia AS konfigūracija yra specifinis sprendimas ir taikomas, pavyzdžiui, domenų vardų sistemų (DNS) realizavime.

Vertinant bendrą regiono interneto tinklą su potinkliais kaip bendrą sistemą, egzistuoja jungtys su tarptautinio interneto ryšio tiekejais. Tokios jungtys ir tokių jungčių AS yra reikšmingi regiono interneto tinklo junglumui. Šie ryšiai užtikrina globalaus interneto tinklo pasiekiamumą vidiniams šalies interneto vartotojams. Atsižvelgiant ị tai, ịvedama nauja, Tier-1 AS. Analizuojant realų tinklą, Tier-1 AS grupei priskiriamos tos AS, kurios yra sujungtos su kitų šalių tinklais. Paprastai tokie sujungimai yra susiję su taip vadinamais Tier-1 lygio AS (Norton 2002). Tier-1 tai yra tinklas kuriuo galima pasiekti bet kuri kitą tinklą Internete be papildomo tranzitinio IP duomenų srauto pirkimo. Tarptautiniai Tier- 1 valdo pagrindinius globalaus interneto duomenų srautus ir interneto hierarchijoje neturi kitų jungčių su aukštesniu lygiu (2.3 pav.). Visos kitos Tranzitinès AS sąlyginai priskiriamos prie Tier-2 lygio, o Vartotojiškos AS - Tier-3 (Oliveira 2010).

Interneto tinklo modelio aprašymas nebus pilnas be ryšių tarp AS identifikavimo. Išskiriame du tarptinklinių sujungimų tipus svarbius AS topologijos aprašymui:

Lygiaverčių mainų tipo ryšys žymi sutartinị duomenų maršrutizavimą tarp panašių AS tinklų, tikslu keistis duomenų srautais tik tarp tų tinklų vartotojų (Norton 2002). Tai dažnai naudojamas sujungimo būdas, tačiau lygiaverčių mai- 
nų tipo ryšiai turi savo apribojimus, nes skirti lygiaverčiam srauto apsikeitimui tarp dviejų konkrečių AS vartotojų. Lygiaverčių mainų ryšiai sutartiniai ir neapmokestinami. Šis apribojimas turi daugiau įtakos AS topologijai valstybės lygyje. Tier-1 lygyje lygiaverčių mainų jungtys vaidina kitą reikšmę, didieji tarptautiniai Tier-1 AS formuoja lygiaverti srautų apsikeitimą per lygiaverčių mainų jungtis. Tai lyg sudaro stuburini globalaus interneto tinklą (Oliveira 2010).

Lygiaverčiu mainų jungtis dar klasifikuojamos i dedikuotas ir viešąsias. Dedikuotiems lygiaverčių mainų ryšiams sudaryti skiriamos atskiros linijos tarp AS, tame tarpe ir fizinès jungtys. Tai susiję su operatyvesniu tokių linijų administravimu, tačiau ekonomiškai yra brangesnis būdas nei vieša lygiaverčių mainų jungtis. Vieša lygiaverčių mainų jungtis realizuojama per lygiaverčių mainų apsikeitimo mazgus (LMMM). Tai fizinė infrastruktūra valdoma nepriklausomo operatoriaus, kurioje ịvyksta fiziné AS (LMMM tinklo dalyvių) jungtis. 2.3 paveiksle realizuota LMMM, kurioje AS jungiasi per fizinę infrastruktūrą. AS pačios sprendžia su kuria kita AS sudaryti lygiaverčių mainų ryšį.

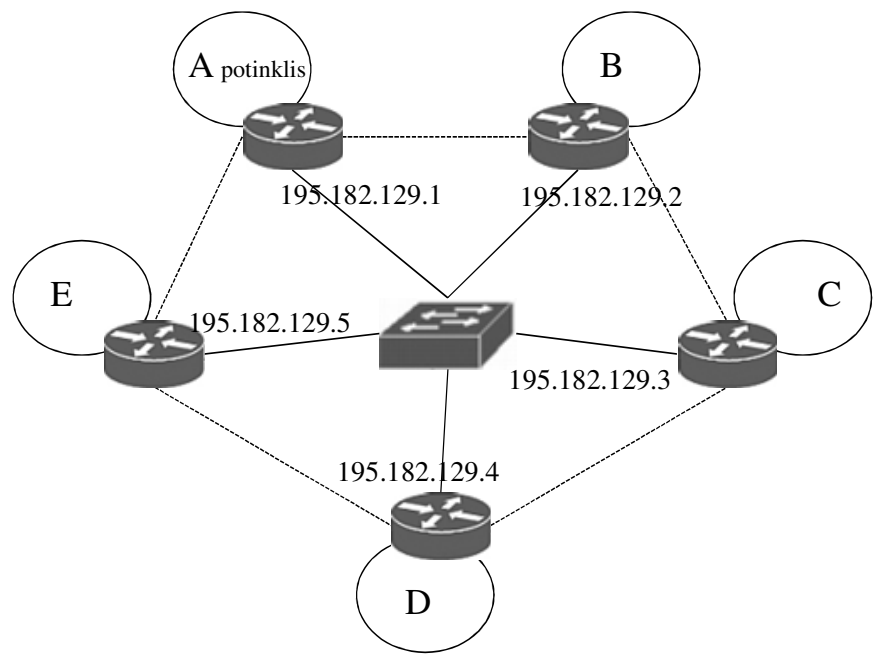

2.3 pav. Lygiaverčių mainų mazgo struktūra

Fig. 2.3. Structure of internet exchange node

IPT lygiaverčių mainų jungčių sudarymui nenaudoja griežtų taisyklių. Lygiaverčių mainų sąryšiui tarp AS turi įtakos AS mazgo dydis, įeinančio/išeinančio duomenų srautų dydžiai, perejjimo mazgų (jungimo žingsnių) skaičius. Dèl šių priežasčių todèl lygiaverčių mainų tipo ryšių tinklas yra atsitiktinis. 
Šiuolaikiniame internete didžiają dalị duomenų srautų sukuria paieškos sistemų (google, bing), turinio (youtube) ir socialiniai tinklai (facebook). Šie tinklai išimtinai sudaro lygiaverčių mainų jungtis su IPT (Oliveira 2010).

Tranzitinio tipo ryšys, tai dedikuotos linijos, kai priimantis duomenis AS užtikrina duomenų persiuntimą link gavejjo. Didžioji dalis duomenų interneto tinkle persiunčiama Tranzitinès tipo ryšiais.

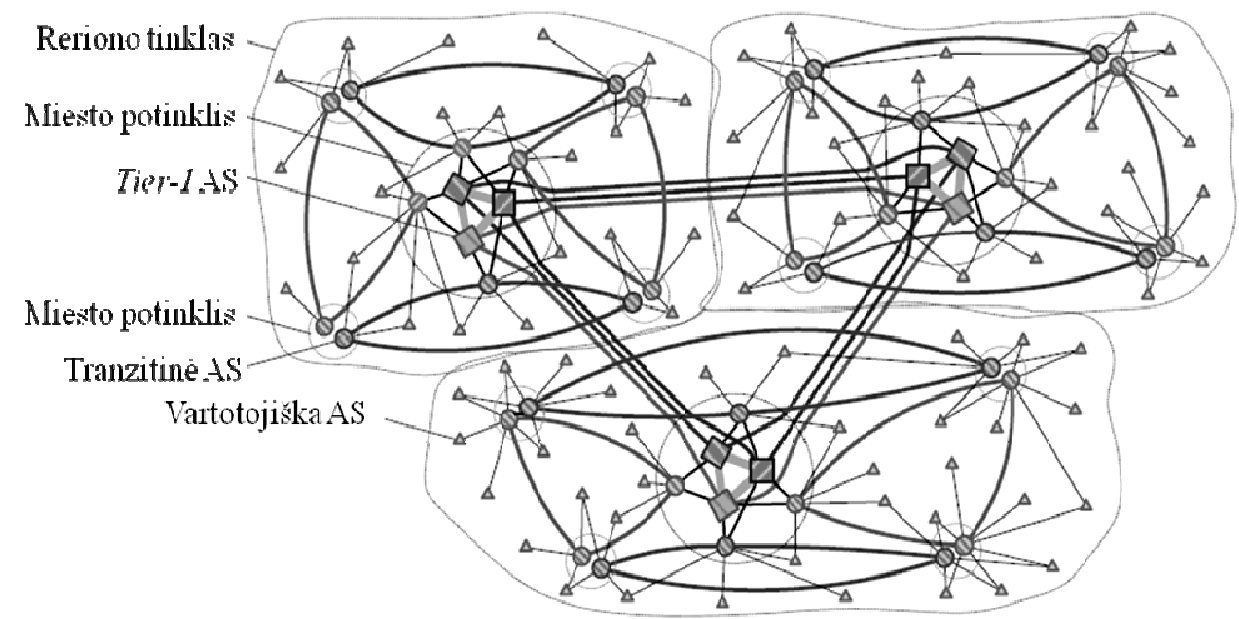

2.4 pav. Hierarchinè interneto topologijos schema

Fig. 2.4. Hierarchical Internet topology layout

Internete suminė AS ir sujungimo linijų klasifikacija formuoja hierarchine tinklo struktūrą, kuri schematiškai išdèstyta 2.4 pav.

\subsubsection{Autonominių sistemų metrikos}

Pradinę interneto topologinès struktūros analizę atliksime pasinaudojant grafų metrikomis: mazgo laipsnis, grupavimas, kaimynystès funkcija ir kita.

Mazgo laipsnis. Grafų teorijoje, grafo viršūnès laipsnis yra skaičius briaunų jungiančių viršūnę (Harju 2007, Norton 2002). Viršūnès laipsnis $v$ žymimas $\operatorname{deg}(v)$. Grafo $G_{i}\left(V_{i}^{k}, U_{i}^{l}\right) \quad k$-osios viršūnès $V_{i}^{k}$ laipsnis $-\operatorname{deg}\left(V_{i}^{k}\right)$ yra lygus $i$ osios AS ryšio linijų su kitomis AS skaičiui $k$. Bendru atveju $k=1, \ldots, K$.

Siekiant charakterizuojant ir atskirti tuos mazgus, kurie yra sujungti su kitų šalių tinklais sąvoka mazgo laipsnis skiriama į dvi dalis pagal požymius: šalies vidaus tarptinkliniams sujungimams $\operatorname{deg}_{i n}\left(V_{i}^{k}\right)$ ir išorès, t. y. Tier-1 tipo, $\operatorname{deg}_{\text {out }}\left(V_{i}^{k}\right)$. 
Taikant AS metriką regioniniam interneto tinklui, ịvedama koncepcija, kad Tier-1 AS, kurios valdo sujungimus su aukštesnio lygio, t. y. tarptautinio interneto ryšio kanalais, yra atsakingos už regionų jungiamumą. Atitinkamai Tranzitinès AS, valdančios sujungimus žemys su vartotojais ir vartotojiškomis AS yra svarbios regiono vidiniam junglumui. Tokia koncepcija suponuoja hierarchinę regioninio tinklo struktūrą bendrame interneto tinkle.

Mazgo laipsnio skirstinys. Tai yra mazgo laipsnių tikimybinis pasiskirstymas tinkle (Norton 2002). Mazgo laipsnio pasiskirstymas $P(\mathrm{k})$ tinkle apibūdinamas kaip mazgų tinkle santykis su laipsniu $k$. Jeigu turime tinkle bendrą skaičių mazgų $n$ ir iš jų $n_{k}$ turi laipsnị $k$, apibūdiname išraiška:

$$
P(\mathrm{k})=n_{k} / n \text {. }
$$

Daugeliui evoliucionuojančių tinklų nuspèti $P(\mathrm{k})$ formą sunku, kol nėra surenkama ir ištiriama detali informacija apie tinklo topologiją. Realiems tinklams $P(\mathrm{k})$ forma gali varijuoti plačiose ribose. $P(\mathrm{k})$ analizè leidžia turi atskleisti interneto tinklo infrastruktūros savybes, svarbias tinklo patikimumo tyrimams.

Grupavimas. Grupavimo technikai pagrindus davẻ socialinių ryšių tinklai. Reprezentatyvi grupe draugų laikoma sugrupuota kai kiekvienas narys pažysta kiekvieną kitą narị. Grupavimo požymio lygiui įvertinti naudojamas grupavimo koeficientas $C$ (Strogatz 1998).

Jeigu pasirinktume $i$-ąją grafo viršūnę ir visas tiesiogines viršūnes jos kaimynes $k_{i}$, tai šių viršūnių sujungimų tinklas gali turèti maksimalų briaunų skaičių lygų $k_{i}\left(k_{i}-1\right) / 2$. Jeigu bendras grafo briaunų tarp viršūnių $k_{i}$ skaičius yra $E_{i}$, $i$-osios viršūnès grupavimo koeficientas bus $C_{i}$.

$$
C_{i}=\frac{2 E_{i}}{k_{i}\left(k_{i}-1\right)} .
$$

Bendrasis tinklo grupavimo koeficientas būtų visų jo viršūnių $C_{i}$ vidurkis. Atsitiktinai sujungtų grafų teorijoje laikoma, $\operatorname{kad} C_{i}=p$. Jeigu grafe yra $N$ viršūnių, $p$ yra tikimybè, kad kiekviena pora viršūnių bus sujungta. Realiuose tinkluose $C_{i}$ yra didesnis esant tam pačiam skaičiui briaunų ir viršūnių (Albert 2002).

Vertinant tinklo patikimumo aspektu, aukštas $C_{i}$ yra teigiama tinklo topologijos junglumo savybè. Kuo didesnè $C_{i}$, tuo didesnè tikimybè, kad kaimyniniai mazgai galès greitai vienas kitą pasiekti, nors tinkle nebūtinai tokio sujungimo distancija bus trumpa.

Gretimumo funkcija. Grafe mazgo gretimumą sudaro mazgų, prijungtų prie šio mazgo per tam tikrą distanciją, aibè. Tai yra ịvertinama skaičiumi žingsnių tarp mazgo-šaltinio ir jo kaimynų (Norton 2002). Mazgo gretimumas charakterizuojamas gretimumo (kaimynystès) funkcija $N(\mathrm{~h})$. Grafo $G=(\mathrm{V}, \mathrm{U})$ gretimumo funkcija yra skaičius sugrupuotų mazgų (interneto topologijoje AS) pasiekiamų atstumu $h$ (Albert 2002). 


$$
N(h)=\sum_{u \in V} N(u, h) .
$$

Atstumo $h$ pasirinkimas tiesiogiai įtakoja funkcijos $N(\mathrm{~h})$ rezultatus. Viena ar keletu linijų sujungta AS per $N(\mathrm{~h})$ apibūdins kiekị tiesiogiai pasiekiamų mazgų. Arba, AS pasiekiama tam tikrame regione (pavyzdžiui, mieste) apibūdins geografini padengiamumą. $N(\mathrm{~h})$ yra patogi ir naudinga sudarant topologinius tinklų žemèlapius (vizualizacija), tačiau nėra reikšminga vertinant tinklo infrastruktūros patikimumą.

Kituose darbuose (Barabási 1999) artimas $N(\mathrm{~h})$ reiškinys dar vadinamas tinklo diametru. Tinklo diametras $L(\mathrm{p})$ tai vidutinis skaičius žinksnių reikalingų nueiti kelią iš vieno mazgo iki kito. Realūs interneto tinklai ir potinkliai turi aukštą $L(\mathrm{p})$, todèl paprastai reikalingas nemažas skaičius žingsnių iš vieno mazgo pasiekti kitą, kuris nèra pirmojo kaimynas.

\subsection{Lietuvos interneto tinklo analizè}

Skirstant tinklo dedamąsias ị hierarchinę struktūrą ir formuojant tinklo topologiją, surinkti reikalingi išeitiniai duomenys apie kiekvieną IPT, apie jo tinklą apibūdinantị grafą $G_{i}(V, U)$, nurodant $N_{i}$ - mazgus, $M_{i}$ - linijas bei ịvertinant jų charakteristikas. Taip pat reikia ịvertinti realias tarptinklinių sujungimų organizavimo taisykles paremtas BGP maršrutizavimo lentelėmis.

Analizuojant Lietuvos regiono interneto tinklo infrastruktūrą, remtasi techniniais duomenimis surinktais tiesiogiai iš IPT infrastruktūros. Taip pat kaip išeitiniai duomenys buvo surinkti iš tarptautinių, viešai prieinamų, globalaus interneto topologijos duomenų bazių (RIPE-RIS ir traceroute tinklo komandų rezultatai).

Šios srities darbuose (Oliveira 2010, Wu 2007) nustatyta, kad interneto topologijos duomenys nèra absoliučiai tikslūs kaip buvo vertinta anksčiau. AS lygio topologija, pagal duomenis surinktus BGP ir traceroute pagrindu, turi reikšmingą paklaidą. Topologijos sudarymas BGP maršrutizavimo lentelių duomenų pagrindu praktikoje gali neįvertinti iki $40 \%$ linijų, pagrinde lygiaverčių mainų tipo (Oliveira 2010). Atitinkamai tiriamųų darbų, kurie globalaus interneto analizei naudoja BGP ir traceroute duomenų bazes, patikimumas yra abejotinas. Siekiant topologijos duomenų kokybès, pasirinkta šio darbo tyrimuose naudoti tiesioginès IPT apklausos duomenimis. Viešosiomis BGP duomenų bazèmis (CAIDA, RIPE) naudotasi tik tais atvejais kai IPT per apklausas duomenų nepateikè arba tuos duomenis buvo siekiama patikrinti.

Kitų autorių tyrimuose (Oliveira 2007) pastebèta, kad teoriniai globalaus interneto tinklo topologijos vertinimai prasilenkia su empirinių tyrimų rezultatais. Tai susiję su interneto kompleksiškumu. Apie 37 tūkst. sujungtų AS ir apie 350 tūkst. IP adresacijos blokų tinklas yra įvairialypis pagal savo technines charakte- 
ristikas (Hall 2011), todèl ne visada tos pačios taisyklès galioja skirtingiems interneto potinkliams. Dẻl to interneto tinklo, apriboto regiono perimetru išreikštu per regionui priklausančių IP adresacijos ruožą, tyrimo privalumas yra patikimesi rezultatai.

Tyrimu identifikuota 37 IPT (iš 64 IPT apie kuriuos surinkti tikslūs duomenys), kurie savo duomenų perdavimą organizavo naudojant AS. Likusieji IPT priskirti Vartotojiškoms AS.

Atlikus AS klasifikaciją nustatyta, kad didžioji dalis Lietuvos interneto tinklo topologijoje yra Vartotojiško tipo AS (81\%), kai tuo tarpu Tranzitinių AS yra tik 12 (19\%) (lentelè 2.1). Nedidelis skaičius Tranzitinio tipo AS gali būti paaiškinamas vidiniais IPT ekonominiais ir tinklo organizavimo niuansais. Interneto patikimumo aspektu nedidelis skaičius Tranzitinių AS gali nulemti, kad AS pažeidimai, pavyzdžiui kryptingos paskirstytosios atsisakymo aptarnauti atakos (PAAA) metu, ženkliai sutrikdys Lietuvos vidinio interneto tinklo veiklą. Objektyviai vertinant, 12-os Tranzitinių AS skaičius yra nedidelis, kad egzistuotų reali tikimybė jog kibernetinių atakų pasekoje dalis arba visos AS bus paveiktos taip, kad Lietuvos interneto tinklas (kaip multigrafas) nebebus jungtinis. Tranzitinès tipo AS buvo nustatyti lyginant tyrimo metu surinktus duomenis tiesiogiai apklausiant IPT su tarptautine RIPE duomenų baze-registru ir joje aprašytomis BGP taisyklėmis (maršrutizavimo lentelès).

11 identifikuotų Tier-1 tipo AS, taip pat yra ribotas resursas užtikrinti globalaus interneto pateikiamumą Lietuvos vartotojams, tačiau jị dar reikia įvertinti linijų pralaidos aspektu.

2.1 lentelè. AS pasiskirstymas pagal tipus

Table 2.1. AS types distribution

\begin{tabular}{|l|l|l|}
\hline \multicolumn{1}{|c|}{ AS tipas } & \multicolumn{1}{|c|}{ Kiekis } & \multicolumn{1}{|c|}{ Procentai, \% } \\
\hline Vartotojiška & $\begin{array}{l}\text { 52 (tame tarpe 4 Kartoti- } \\
\text { nés AS) }\end{array}$ & 81 \\
\hline Tranzitine & $\begin{array}{l}\text { 12 (tame tarpe 11 Tier-1 } \\
\text { AS) }\end{array}$ & 19 \\
\hline
\end{tabular}

Ryšių tipų klasifikacija (2.2 lentelè) parodè, kad Lietuvos interneto infrastruktūroje vyrauja lygiaverčių mainų tipo sąryšiai tarp AS (76 \%). Tačiau reikalinga ịvertinti tai, kad internete didžioji dalis duomenu perdavimo vyksta tranzitinio tipo ryšiais, kurie Lietuvos interneto topologijoje tesudaro $24 \%$ tinklo infrastruktūros. Nagrinėjant tinklo patikimumo aspektu, yra siektina, kad tranzitinio tipo ryšių dalis būtų dominuojanti. Taip pat pagal savybes tranzitinès jungtys yra universalesnès ir turi mažiau apribojimų srauto perdavimui. 
Aprašytą hierarchinę tinklo struktūrą tikslinga papildyti ịvertinant AS svarbos ar reikšmingumo kriterijų, aukščiausią lygi priskiriant toms AS, kurios tiesiogiai yra sujungtos su kitų šalių tinklais.

Regioninio tinklo AS topologijoje ryšiai su tarptautiniais (Tier-1 tipo) AS vaidina svarbų vaidmeni, todèl jų vertinimas atskirai nuo vidaus regiono sujungimų yra prasmingas. 2.3 lentelèje pateikiame mazgų laipsnių pasiskirstymą vidiniams $\operatorname{deg}_{\text {in }}\left(V_{i}^{k}\right)$ tiek išoriniams $\operatorname{deg}_{\text {out }}\left(V_{i}^{k}\right)$ Tranzitinès tipo sujungimams. Analogiškai galima pateikti duomenis ir Lygiaverčių mainų tipo sujungimams.

2.2 lentelè. Ryšių tipų pasiskirstymas

Table 2.2. Distribution of connections types

\begin{tabular}{|l|l|l|}
\hline \multicolumn{1}{|c|}{ Sujungimo tipas } & Kiekis & Procentai, \% \\
\hline Lygiaverčiu mainų & 373 & 76 \\
\hline Tranzitinès & 117 & 24 \\
\hline
\end{tabular}

Disponuojant realiais duomenimis apie mazgų laipsnius (tiek vidiniams tiek išoriniams sujungimams), apskaičiavome $P(k)$ tranzitinėms ir lygiaverčių mainų sujungimų tipams (2.5 pav.).

2.3 lentelè. Mazgų laipsniai pagal Tranzitinio tipo ryšius

Table 2.3. Node degree for Transit type connections

\begin{tabular}{|l|l|l|}
\hline \multicolumn{1}{|c|}{ AS numeris } & \multicolumn{1}{|c|}{$\operatorname{deg}_{\text {in }}\left(V_{i}^{k}\right)$} & \multicolumn{1}{c|}{$\operatorname{deg}_{\text {out }}\left(V_{i}^{k}\right)$} \\
\hline AS1 & 44 & 5 \\
\hline AS2 & 10 & 2 \\
\hline AS3 & 25 & 2 \\
\hline$\ldots$ & $\ldots$ & $\ldots$ \\
\hline AS $_{\mathrm{i}}$ & $\mathrm{K}_{\text {in }}$ & $\mathrm{K}_{\text {out }}$ \\
\hline
\end{tabular}

Analizuojant mazgų laipsnių pasiskirstymo (2.5 pav.) galima daryti išvadas, kad Lietuvos interneto tinklo AS topologijoje yra nedidelis skaičius mazgų, turinčių pakankamai didelị kiekị Tranzitinès tipo sujungimų. Tik 1 mazgas turi 47 Tranzitinès tipo sujungimus, kai tuo tarpu didžioji dalis mazgų turi tik 1 $P(\mathrm{k})=0,48$ ar $2 P(\mathrm{k})=0,28$ sujungimus. Tinklo patikimumo aspektu, vienas mazgas turi didelę ịtaką bendrai tinklo topologijai, kai tuo tarpu didžioji dalis mazgų (AS) turi pasikliauti 1-2 ryšių veiklos patikimumu. Lygiaverčių mainų tipo mazgo laipsnių pasiskirstymas yra tolygesnis negu Tranzitinès tipo jungčių. 


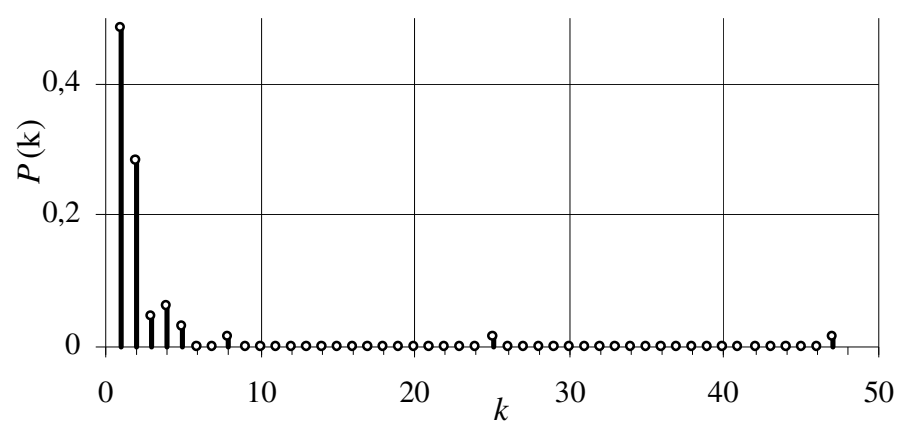

a)

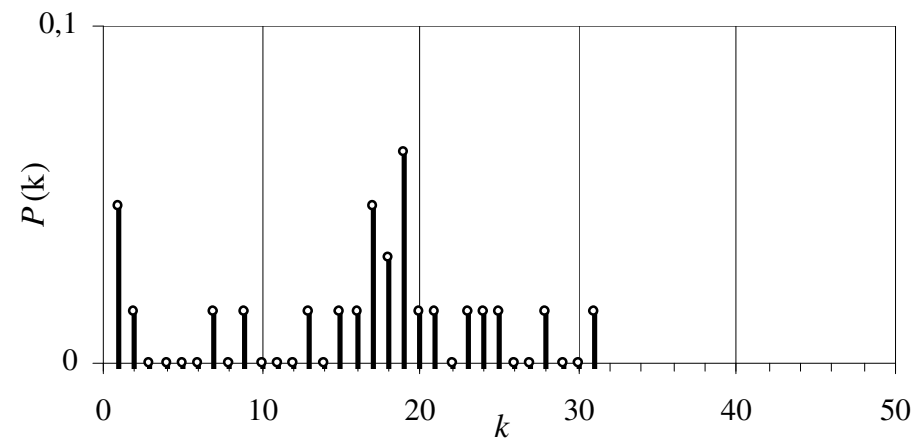

b)

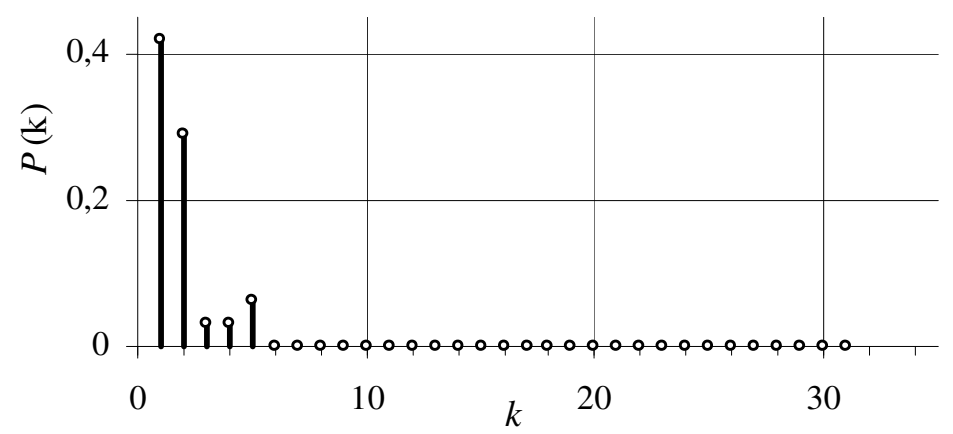

c)

2.5 pav. Mazgo laipsnių pasiskirstymo pagal ryšių tipus diagramos: a) Tranzitinès; b) lygiaverčių mainų; c) Tier-1 AS

Fig. 2.5. Nodes degree distribution for types of connections: a) Transit; b) Peering; c) connecting Tier-1 AS 
Vykdant tinklo analizę, reikia atkreipti dėmesi ị tai, kad AS topologijos yra kintamos, dinamiškos (Zhang 2005, Hawkinson 1996). Atsiranda naujos AS ir nauji ryšiai tarp jų. Todèl AS topologijai apibūdinti naudojami duomenys turi būti nuolat atnaujinami. Idealiu atveju visi atnaujinimai turètų būti fiksuojami realiu laiku.

Grupavimo koeficientas apskaičiuotas Lietuvos interneto tinklui yra $C_{\mathrm{LT}}=0,23$. Atskirai vertinant tranzitinio tipo sujungimų tinklą $C_{\text {transit }}=0,05$, o lygiaverčių mainų jungčių atveju $C_{\text {peering }}=0,17$. Pilnai jungtinio grafo $C_{i}=1$, todèl apskaičiuotas $C_{\mathrm{LT}}$ rodo, kad junglumas tinkle yra žemas, o mažiausia išraiška yra $C_{\text {transit. }}$ Tinklo vientisumas bus geriau užtikrintas, jeigu tinklo grupavimo koeficientas bus kuo aukštesnis.

\subsection{Antrojo skyriaus išvados}

Regiono interneto tinklas, jo topologijos savybiu tyrimui, atvaizduojamas multigrafu, kurio viršūnès yra AS, o briaunos - ryšio jungtys.

1. Interneto topologinès struktūros patikimumo analizei geriausiai tinka ryšių grafų metodai, išskiriant mazgų laipsnius, mazgų laipsnių pasiskirstymą ir grupavimą.

2. Regiono interneto tinklo analizei sudarytas hierarchinis tinklo modelis, išskiriant tinklui būdingus AS ir jungčių tipus. Išskiriamos AS: Vartotojiška AS, Tranzitinė AS, Kartotinė AS, Kartotinė AS ir Tier-1 AS. Skiriami jungčių tipai: Lygiaverčių mainų ryšiai ir Tranzitiniai sujungimai.

3. Atlikus Lietuvos interneto tinklo topologijos analizę nustatyta:

- Didžiają dali topologijos užima Vartotojiško tipo AS (81\%);

- Tranzitinio tipo AS sudaro tik 19 \% tinklo infrastruktūros, o Tier-1 AS yra tik 11.

4. Pagal sudarytą metriką, mazgo laipsnių pasiskirstymą, Lietuvos interneto tinklo topologijoje:

- $\quad$ yra tik vienas mazgas (AS) valdantis 47 tranzitinių jungčių;

- $76 \%$ mazgų valdo tik 1-2 tranzitines jungtis su kitomis AS;

- mazgo laipsnių pasiskirstymas mazguose pagal lygiaverčių mainų ryšius yra tolygus ir dominuojantis lyginant su kitais ryšių tipais. 


\section{Kritinių interneto infrastruktūros komponentų nustatymas}

Skyriuje tinklo topologijos analizès pagrindu nagrinèjama fundamentali interneto savybè - tinklo junglumas. Sudaryta metrika, kuri leidžia nustatyti kritinius interneto infrastruktūros elementus: kritinius ir $\eta$-kritinius mazgus bei kritines ir $\kappa$-kritines linijas. Suformuluotas kritinių tinklo elementų stebėsenos modelis, aprašytas stebėsenos realizavimo algoritmas.

Skyriaus tematika paskelbtas vienas autoriu straipsnis (Kajackas, Rainys 2011).

\subsection{Problemos formulavimas}

Dèl didelio spektro IT sistemų, skirtingų taikomujų programų ir jų konfigūracijų, egzistuoja didelè tikimybė pažeidžiamumus išnaudoti kibernetinėms atakoms realizuoti. Kibernetinès atakos klasifikuojamos pagal plitimo pobūdị, greitị, itaką IT ir pan. (Paulauskas 2006). Kai kurios iš atakų turi ịtakos interneto tinklo (ar jo dalies) veiklos stabilumui, nes pažeidžia svarbias interneto veiklai sistemas. Kadangi tokių atakų skaičius auga, tai susiję su normalios interneto tinklo veiklos pakitimais. Dažnai tokių atakų taikiniais yra labiausiai pažeidžiami tinklo infrastruktūros elementai. Darbe (Knight 2009) konstatuojama, kad tinklo 
plètra turi adaptuotis prie situacijos, o tinklo elementai būti pritaikyti ne tik suprojektuotiems duomenų srautams, bet ir kibernetinių atakų ịtakai.

Iprasta, kad duomenų perdavimo sistemų paslaugos kokybė vertinama pagal prarastus paketus, duomenų perdavimo spartą ir pan. Tačiau, reikètų vertinti ir tinklo funkcini patikimumą, kaip tam tikrą kokybinę paslaugos išraišką. Pagal 1 skyriuje pateikiamas saugumo incidentų įtakos vertinimus, interneto vartotojai, nuolat susidurdami su tinklais plintančiu kenksmingu programiniu kodu, nepageidaujamais elektroninio pašto laiškais (spam) ir kibernetinėmis atakomis, negauna pilnavertès paslaugos. Pavyzdžiui, nepakankamai apsaugotas tinklas gali būti pažeistas PAAA atakos ir vartotojas gali nebegauti interneto prieigos paslaugos apskritai. Darytina išvada, kad galinio vartotojo atžvilgiu saugumo incidentai tinkle turi ịtakos interneto paslaugos kokybei.

Bangos ilgių sutankinimo (WDM) tinkluose esantys dažni technologiniai duomenų perdavimo srauto (kanalo) nutrūkimai buvo priežastis ieškoti būdų gerinti WDM tinklų patikimumą. Šios srities tyrimuose pradèta naudoti sąvoka patikimumo kokybè (Arakawa 2003). Patikimumo kokybès vertinimo analogijos pritaikomos ir interneto tinklo patikimumo analizeje. Darbe (Owezarski 2006) nagrinėjamas interneto patikimumo klausimas, pasitelkiant interneto paslaugu kokybès (QoS) užtikrinimo būdus. Naudojama matavimais paremta tinklo architektūra, gebanti užtikrinti numatytą paslaugos kokybę gedimų, perkrovų ir PAAA ataku atvejais. Principas paremtas tinklo srauto matavimais realiu laiku ir mechanizmų, galinčių prisitaikyti prie pasikeitusių sąlygų, naudojimu. Ši praktika leidžia teigti, kad interneto patikimumo kokybę ịtakoja tinklo infrastruktūros elementų veikimo kokybè. Kitaip, tinklo infrastruktūros elementų veiklos sutrikimai (dèl kibernetinių atakų ar gedimų) turi ịtakos tinklo patikimumo kokybei.

Kitas problemos aspektas yra telekomunikaciju procesai internete. IPT formuoja savo tinklus individualiai pagal vykdomo verslo interesus, technines tinklo plètros galimybes ir vartotojų poreikius. Kiekvienas IPT valdo tik savo tinklo maršrutizatorius ir formuoja savo tarptinklinių sujungimų strategiją, savo nuožiūra atlieka tinklo perimetro stebèseną, apsaugą bei tinklo funkcionalumo patikimumą. Sujungimai su kitais tinklais taip pat formuojami pačių IPT iniciatyva naudojant BGP protokolą AS maršrutizavimo lentelèms sudaryti. Tokia jungtiné potinklių sistema formuoja hierarchinę interneto struktūrą (Gao 2000). Bendras stochastiškai suformuoto interneto tinklo priklauso nuo ịvairių faktorių, tame tarpe nuo tinklo topologijos ir nuo atskirų tinklo elementų (AS) patikimumo.

Šios prielaidos leidžia teigti, kad stochastiškai suformuoto interneto tinklo infrastruktūroje yra kritiniai elementai, kurių pažeidimai turi ịtakos bendram tinklo funkcionalumui. Tinklo elementų pažeidimai gali būti susiję su kibernetinių atakų veikla ar atsitiktiniais gedimais. Kritinių interneto tinklo elementų nustatymo uždaviniui išspręsti reikia sukurti metodologiją. 


\subsection{Metodologija ir kriterijai}

Interneto tinklo analizei paprastai yra taikoma grafų teorija (Ekmanis 2010, Chang 2004, Subramanian 2002). Darbuose (Lauks 2009, Jeļinskis 2009) grafú teorija pritaikoma srautų analizei bei srautu inžinerijai tinkle, kai tuo tarpu pritaikymo praktikos interneto tarptinklinių sujungimų tyrimų srityje nepakanka.

Interneto tinklo segmentas atvaizduojamas kaip grafas $G_{\text {net }}$, kurio viršūnèse yra autonominès sistemos (AS). Stacionari tinklo būsena atitinka jungtini grafą. Tokiame grafe yra bent vienas kelias tarp $i$-osios AS ir bet kurios kitos AS, priklausančios $G_{\text {net }}$. Šio darbo 2 skyriuje nagrinèta Lietuvos regiono interneto tinklo infrastruktūros topologija ir ją atitinkantis grafas.

Grafo $G_{\text {net }}$ ypatingos svarbos (kritiniai) elementai žymimi $u$. Tokias $u$ sudaro kritiniai mazgai ir kritinès linijos, o jų apibūdinimas nèra vienareikšmis ir gali kisti priklausomai nuo kriterijų.

Pagal griežtają taisyklę grafo mazgas yra kritinis jeigu jo eliminavimas išskaido pradini grafą i subgrafus. Išplèstine kritinio mazgo $V_{\mathrm{c}}$ charakteristika apibūdina $V_{\mathrm{c}}$ kaip mazgą, kurio eliminavimas ar sutrikdymas pradini grafą išskaido arba reikšmingai pablogina tinklo savybes (Lauks 2009).

Toks dviejų dalių mazgo apibūdinimas apsunkina kritinių mazgų paiešką. Ivardinti pokyčiai „išskaido arba reikšmingai pablogina tinklo savybes” realiai nustatomi skirtingais būdais. Todèl šiame darbe taikomi du apibrež̌imai: kritinis mazgas ir $\eta$ - kritinis mazgas.

Kritiniu laikysime mazgą, kurio eliminavimas ar sutrikdymas išskaido pradinị grafą ị du ar daugiau atskirų subgrafų, neturinčius tarpusavio ryšių.

$\eta$ - kritiniu laikysime mazgą, kurio eliminavimas žymiai pablogina tinklo savybes daugeliui $(\eta A)$ vartotojų.

Pagal pirmaji požymị apibūdintiems kritiniams mazgams nustatyti taikytinas formalus grafo viršūnių išèmimo metodas. Jeigu $i$-osios AS pašalinimas sukuria atskirus tarpusavio ryšio neturinčius subgrafus - tokia AS laikoma $V_{\text {c }}$.

Patikslinant antraji požymį, $\eta$ - kritinio mazgo apibūdinimą, šiame darbe mazgo kritiškumas vertinamas susietai su prie $i$-osios AS prisijungusių interneto vartotojų skaičiumi $A_{i}$. Mazgo kritiškumo indeksas $\eta$ išreiškiamas santykiu:

$$
\eta_{i}=\frac{A_{i}}{\sum_{j=1}^{J} A_{j}} .
$$

Čia $\Sigma A_{j}$ yra bendras regiono interneto tinklo vartotojų skaičius.

Kad būtų patogiau, $\eta$ - kritinio mazgo išraišką skirstysime ị dvi kategorijas: $\eta_{i} \geq 0,1$ ir $\eta_{i}<0,1$. Atitinkamai $\eta_{i} \geq 0,1$ mazgų reikšmè (kritiškumas) bendroje tinklo infrastruktūroje yra didžiausias. 
Kritine linija $E_{\mathrm{c}}$ apibūdinamas taip pat nevienareikšmiai. Vienas iš tokių apibūdinimu yra ,briauna $A B$ yra kritinè jeigu abu galiniai taškai $A$ ir $B$ yra kritiniai mazgai“. Kitaip, $E_{c}$ yra ryšys jungiantis kritinius mazgus taip, kad eliminavus tokią liniją grafą nustoja būti jungtiniu (Lauks 2009).

Atliekant $E_{c}$ nustatymą $G_{\text {net }}$ laikomas sudarytu iš visų IPT veikiančių interneto tinkle, atitinkančių grafo viršūnes. Aktualu ịvertinti ir tas ryšio linijas, kurių pašalinimas mažesnius IPT (neturinčius AS) atjungs nuo nacionalinio interneto tinklo.

Pagal analogiją su šiame darbe suformuluotomis kritinio mazgo sampratomis toliau taikomi du apibrezžimai: kritinè linija ir $\kappa$ - kritinė linija.

Kritine laikysime liniją, kurios eliminavimas ar gedimas suformuoja kelis atskirus subgrafus neturinčius tarpusavio ryšio (briaunų).

$\kappa$ - kritine linija laikysime liniją, kurios eliminavimas ar gedimas žymiai pablogina tinklo jungiamumo savybes.

$E_{\mathrm{c}}$ nustatymas pagal pirmajj požymį atliekamas analogišku $V_{\mathrm{c}}$ principu grafo briaunų išèmimo būdu. Jeigu $n$-osios briaunos pašalinimas sukuria atskirus tarpusavio ryšio neturinčius subgrafus - tokia linija laikoma $E_{\mathrm{c}}$. Mūsų atveju nagrinejjamas grafas atitinka regioninį interneto tinklą kartu su $N_{\text {int }}$ sujungimais. $N_{\text {int }}$ yra linijos jungiančios regioninio tinklo AS su tarptautinio interneto tinklo tiekèjo AS. Tokiu atveju taikant briaunų išèmimo metodą $N_{\text {int }}$ atitiks $E_{c}$.

Patikslinant $\kappa$ - kritinès linijos sampratą, ji siejama su linijos pralaidos parametru $\Delta$. Vertinsime linijos priklausančios $i$-ajjai AS maksimalią instaliuotą pralaidą $\Delta_{\max }$ su $i$-osios AS valdomų sujungimu suminiu pralaidos parametru $\Sigma B w$. Šis santykis išreiškiamas pralaidos koeficientu $\eta_{A S}$ :

$$
\eta_{A S}=\frac{\Delta_{\max }}{\sum_{k=1}^{K} B w} .
$$

Čia $\Delta_{\max }$ yra $i$-osios AS maksimali instaliuota pralaida, $\mathrm{Gb} / \mathrm{s} ; \Sigma B w$ yra $i$-osios AS valdomų sujungimų $k$ suminè pralaidą, $\mathrm{Gb} / \mathrm{s}$.

$\eta_{A S}$ apskaičiavimas parodo linijos reikšmę $i$-osios AS jungiamumui lyginant su kitomis $i$-osios AS linijomis. $\kappa$ - kritines linijas suskirstysime i dvi kategorijas: $\eta_{A S} \geq 0,8$ ir $\eta_{A S}<0,8$. Atitinkamai $\eta_{A S} \geq 0,8$ liniju reikšmè (kritiškumas) bendram $i$-osios AS jungiamumui yra didžiausia. Iš esmès, minètos sąlygos tenkinimas parodo $i$-osios AS neproporcingą resursų paskirstymą.

Analizuojant $\kappa$ - kritines linijas $\left(E_{c \kappa}\right)$, tenkinančias sąlygą $\eta_{A S} \geq 0,8$, paskaičiuojami jų apkrovų intensyvumai (trafikas). $n$-osios linijos $(n=1,2, \ldots$, $\left.E_{c \kappa}\right)$, duomenų srauto $\Delta_{\text {traffic }}(\mathrm{Gb} / \mathrm{s})$ santykis su $\Delta_{\max }$ parodo linijos apkrovą išreikštą linijos apkrovos koeficientu $\lambda_{n}, \lambda_{\mathrm{n}}=\Delta_{\text {traffic }} / \Delta_{\text {max }}$. Tai yra dinaminis para- 
metras ir skiriasi nuo aukščiau nagrinètų, kurie yra daugiau statiniai. $\Delta_{\text {traffic }}$ vienas reikšmingiausių ir labiausiai IPT stebimų tinklo parametrų.

Realiame tinkle, esant normaliai būsenai, ryšio linijos nèra perkrautos ir paprastai turi rezervus. Tačiau priklausomai nuo vartotojų aktyvumo ar kibernetinių atakų sukurtų duomenų srautų, ryšio intensyvumas gali viršyti instaliuotą pralaidumą. Esant sąlygai kai $\lambda_{n} \geq 0,8$, nurodo artejjimą prie kritinių linijos resursų išnaudojimo, o daugiau nei vienos linijos apkrovos artejjimas prie kritinès ribos gali būti susijęs su vykstančia kibernetine ataka, kuri savo ruožtu gali privesti prie žymaus viso tinklo jungiamumo degradacijos.

\subsection{Taikymas}

Sukurta metrika pritaikyta praktikoje interneto tinklo infrastruktūros kritinių elementų identifikavimui. Taikyme naudotasi Lietuvos regiono interneto tinklo infrastruktūros duomenimis iš 2 skyriaus tyrimų.

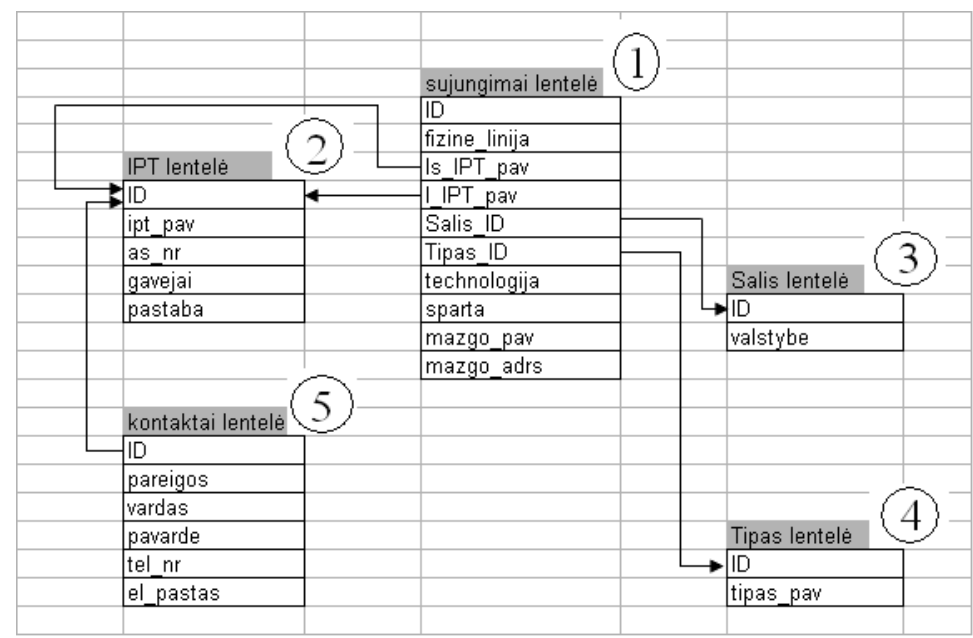

3.1 pav. Tinklo vizualizacijos duomenų bazès struktūrinè schema

Fig. 3.1. Structure of network visualization data base

Lietuvos interneto tinklo modelio sudaryme naudotas didelis kiekis techninių duomenų, kuriems apdoroti pasirinkta kurti duomenų bazę. Duomenų bazè turi susisteminti duomenis ir palengvinti operavimą jais. Pasirinkta struktūrizuotų užklausų kalba (SQL) paremta duomenų bazès struktūra su MySQL realizacija. Sukurtos duomenų bazès struktūra (3.1 pav.) sudaryta iš:

a) Pagrindinès lentelès Nr.1 per kurią pasiekiamos visos kitos lentelès. Joje saugomi tarptinklinių sujungimų duomenys, tokie kaip AS tarpusavio jungtys, 
kokia technologija naudojama, sparta, su kokia šalimi yra organizuotas sujungimas, bei kokiame mazge realizuotas sujungimas;

b) Lentelès Nr. 2, kurioje ịrašyti duomenys apie AS, pavadinimas, autonominès sistemos numeris, turimas interneto paslaugu gavėjų skaičius;

c) Lentelès Nr. 3, kurioje nurodyta AS fizinè dislokacija, šalis.

d) Lentelès Nr. 4 su saugoma informacija apie sujungimų tipus (tranzitinè ar kita).

e) Lentelès Nr. 5, kurioje įrašyti AS administratoriaus duomenys.

Duomenims i lenteles suvesti, o taip pat juos atvaizduoti, sudaryta aplikacija dinaminès interpretuojamos programavimo kalbos (PHP) pagrindu. Tokiu būdu galima operatyviai atvaizduoti ịvairius duomenis, kurie yra išskaičiuojami iš MySQL duomenų bazès apdorojant PHP, kaip pavyzdžiui: AS lygiaverčių mainų sujungimų schema; bendrą ar konkretaus AS išèjimo ị užsienị spartą; kiek AS yra susijungę per konkretų lygiaverčių mainų maršrutizavimo mazgą LMMM ir pan. Vienas operatoriui aktualiausių duomenų bazès panaudojimo aspektų yra Lietuvos interneto tinklo schemos grafinis atvaizdavimas.

Duomenų bazès pagrindu atlikus eksperimentus viršūnių išèmimo metodu, grafe sudarytame iš AS mazgų, identifikuoti 4 kritiniai mazgai $\left(V_{c}\right)$. Nuo $V_{c}$ priklauso bendras tinklo junglumas. Siektina, kad tokių $V_{c}$ tinkle būtų mažiau, o tas pasiekiama formuojant papildomas jungtis tarp AS.

Tuo tarpu $\eta$ - kritinių mazgų, tenkinančių sąlygą $\eta_{i} \geq 0,1$, nustatyta 3 . Pastebėta, kad vienas iš jų sutampa su atitinkamu kritinių mazgu $V_{c}$. Taip pat pastebèta, $\operatorname{kad} \eta_{i}$ sąlygos didinimas tiesiogiai lemia $V_{c}$ didejjimą.

Kritinių linijų $\left(E_{c}\right)$ paieška grafe atitinkančiame Lietuvos interneto tinklą sudètinga dèl didelès aibès. $E_{c}$ paieška vyksta tarp apie 500 tarptinklinių sujungimo linijų, todèl matematinis apskaičiavimų variantų modelis reikalauja laiko ir kompiuterinių resursų. Eksperimentinių tyrimų rezultatai 3.1 lentelèje.

3.1 lentelė. Tinklo kritinių elementų nustatymo rezultatai

Table 3.1. Network critical elements calculation results

\begin{tabular}{|l|l|l|l|}
\hline \multirow{3}{*}{$\begin{array}{c}\text { Kritinis } \\
\text { elementas }\end{array}$} & \multicolumn{1}{|c|}{ Kriterijus } & \multicolumn{1}{c|}{ Sąlygos } & Rezultatai \\
\hline \multirow{4}{*}{$V_{c}$} & \multicolumn{2}{|l|}{ Mazgų eliminavimo metodas } & 4 \\
\cline { 2 - 4 } & \multirow{2}{*}{ - kritinis mazgas } & $\eta_{i} \geq 0,1$ & 3 \\
\cline { 3 - 4 } & & $\eta_{i} \geq 0,2$ & 11 \\
\cline { 3 - 4 } & & $\eta_{i} \geq 0,3$ & 25 \\
\hline \multirow{3}{*}{$E_{c}$} & \multicolumn{2}{|l|}{ Linijų eliminavimo metodas } & 26 \\
\cline { 2 - 4 } & \multirow{2}{*}{$\kappa-$ kritinè linija } & $\eta_{A S} \geq 0,9$ & 2 \\
\cline { 3 - 4 } & & $\eta_{A S} \geq 0,8$ & 13 \\
\cline { 3 - 4 } & & $\eta_{A S} \geq 0,5$ & 33 \\
\hline
\end{tabular}


Linijų išèmimo metodu nustatytos 26 kritinès linijos. Tinklo grafe yra 26 variantai kai jungtis grafą išskaido (grafas nustoja būti jungtiniu). Interneto patikimumo aspektu didejantis $E_{c}$ skaičius yra neigiamas faktorius. $E_{c}$ jungties pažeidimas blogina viso tinklo junglumą. Praktikoje reikia siekti mažinti $E_{c}$, t. y. mažinti tinklo patikimumo priklausomybę nuo $E_{c}$.

$\kappa-$ kritinių linijų $\left(E_{c \kappa}\right)$ paieška taikyta kiekvienam IPT atskirai. Nustatyti tik 2 IPT (nepriklausantys $E_{c}$ ), kurių tarpe yra $E_{c \kappa}$, tenkinančios sąlygą $\eta_{A S} \geq 0,9$.

\subsection{Stebèsena}

Nustatytus $V_{\mathrm{c}}$ ir $E_{\mathrm{c}}$ tikslinga nuolat stebėti, kad kritinių tinklo elementų gedimai ar kritiniai linijų apkrovų resursų išnaudojimai būtų nustatyti ir ịvertinti. Stebėsenos veiksmas yra svarbus nustatyti kritinių elementų gedimus laiku, nes tokių elementų netekimas praktiškai ịtakoja bendrą tinklo funkcionalumą. Gedimų nustatymui kaip priemonę naudosime detektorius esančius subgrafe $G_{\mathrm{c}}$, sudarytame iš viršūnių $V_{\mathrm{c}}$ ir briaunų $E_{\mathrm{c}}$. Detektoriai nuolat komunikuodami tarpusavyje vykdo tinklo stebėseną.

Paprasčiausias būdas stebėsenai atlikti yra periodiškas tinklų komutacijos mazgų patikrinimas (apklausa). Tai atliekama interneto kontrolès žinučių protokolo (ICMP) apimtyje esančiomis ping, tracepath, pathping ar traceroute komandos. Šios komandos gerai žinomos ir plačiai naudojamos tinklo administratorių. Nėra sudėtinga sudaryti programą, kad komanda nuolat (pavyzdžiui, 10 min intervalais) tikrintų visų kritinių mazgų atsaką (gyvybingumą), o pats procesas būtų automatizuotas. Jeigu kuris nors tinklo mazgas neatsiliepia ị užklausos komandą, operatoriaus prižiūrimame tinklo topologijos žemèlapyje būtų atvaizduojamas įspejjimas apie gedimą, o tokio mazgo patikrinimo periodiškumas sutankinamas (pavyzdžiui $1 \mathrm{~s}$ intervalais) kol nebus gautas atsakas apie mazgo funkcionalumo atstatymą. Teigiama tokio metodo savybè yra nepriklausomumas, nes užklausos gali būti generuojamos ir iš šalies, nesant tinklo perimetre, susitarimai su maršrutizatorių administratoriais dèl sensorių talpinimo nèra būtini. Metodas patogus, pavyzdžiui, tinklų reguliavimo institucijoms ar mokslinių tyrimų vykdytojams. Tačiau pats metodas yra nelankstus. Centrinis stebėsenos serveris gauna tik ribotą techninę informaciją apie tinklo mazgo neveiklumą. Techninių mazgo charakteristikų kaitos informacija nepasiekiama. IPT technologiškai gali nustatyti, kad tinklo elementai neatsakinètų i šias komandas. Tokie elementai iškristų iš stebèsenos sistemos.

Kritinių elementų stebėsenos uždavinio sprendimas paremtas SNMP (paprastasis tinklų valdymo protokolas, angl. Simple Network Management Proto$\mathrm{col}$ ) protokolu. SNMP yra aplikacijų lygio protokolas integruotas ị daugeli šiuolaikinių tinklo ịrenginių palaikančių TCP/IP, todèl ji galima panaudoti centralizuotai stebėsenai organizuoti. SNMP veikimas paremtas duomenų pagal 
nustatytus kintamuosius surinkimu iš nutolusių įrenginių, mūsų atveju tai bus tinklo maršrutizatoriai, ị valdymo sistemą (Case 1990). Reikalingi kintamieji gali būti nurodomi iš valdymo sistemos arba iš anksto nustatyti. Programiniai komponentai (agentais) veikia kiekviename iš stebimų mazgų, registruoja ir siunčia duomenis per SNMP ị valdymo sistemą. SNMP leidžia vykdyti aktyvų tinklo valdymą, pavyzdžiui, galima atnaujinti ar pakeisti tinklo konfigūraciją apsikeičiant komandomis tarp valdymo sistemos ir tinklo mazgų. Toks stebėsenos metodas lankstesnis, leidžia rinkti daugiau techninès informacijos, tačiau jam realizuoti integruoti agentai IPT mazguose. SNMP yra standartizuotas protokolas turintis galimybių ìvairiems pritaikymams, todèl gali būti adaptuotas praktiškai bet kokiems tinklo įrenginių parametrams fiksuoti.

SNMP principu paremta stebėsenos sistema realizuojama sekančiais etapais:

1. siunčiamas užklausimas ị $V_{c}$ (SNMP agentas);

2. iš SNMP agento gaunamas atsakas, kuris priimamas stebėsenos sistemoje (SNMP serveris);

3. apdorojami ir išsaugomi duomenų bazèje matavimų duomenys.

Sukurtas kritinių interneto tinklo elementų stebėsenos algoritmas praktiniam stebėsenos realizavimui pateiktas 3.2 pav.

Stebimi mazgai tinkle valdomi SNMP protokolu read, write ir trap tipu pagrindinemis komandomis. Organizuojant stebėseną, komanda read skirta periodiškai nuskaityti duomenis, trap asinchroniškai raportuoti valdymo sistemai apie ịvykius, tokius kaip ryšio sutrikimai, duomenų srauto kritinis lygis ir pan. Kokią informaciją agentas stebimame tinklo įrenginyje rinks, priklauso nuo valdymo informacijos bazès (VIB). Stebėsenai atlikti agentai ịvedami ị tinklo maršrutizatorius. Tokiu atveju VIB tekstinis failas (duomenų lentelè) parenkama aprašyti sekančius parametrus: tinkle galimas ryšio klaidas, srauto kitimus kiekviename kanale. VIB tekstinis failas ir atitinkamai stebimi techniniai parametrai gali būti keičiamas. Tam naudojama traversal komanda, kuri parodo kokius kintamuosius maršrutizatorius gali palaikyti. Naudojant write komandą galima pakeisti VIB failą pagal valdymo sistemos operatoriaus poreikius.

Praktiniam realizavimui pasirinktas Ethernet Statistics Group VIB (Waldbusser 1995), skirtas $\lambda_{\mathrm{n}}$ apskaičiavimui SNMP agente. Dvipusiam kanalui $\lambda_{\mathrm{n}}$ apskaičiuojamas pagal formulę 3.3 ịvertinančią ịejimo/išejjimo (žymima in/out) srauto reikšmes:

$$
\lambda_{n}=\frac{\max \left(\Delta_{\text {in }}, \Delta_{\text {out }}\right) \times 8}{\Delta t \times \Delta_{\max }}
$$

$\Delta_{\text {in }}-$ dvieju SNMP ifInOctets agento apklausos ciklų skirtumas, skaičiuojamas iejejimo srauto kanale, bitai (Waldbusser 1995). 
$\Delta_{\text {out }}$ - dviejų SNMP ifOutOctets agento apklausos ciklų skirtumas, skaičiuojamas išèjimo srauto kanale, bitai (Waldbusser 1995).

$\Delta_{\max }$ - greitis sąsajoje vertinamas snmpifSpeed objekte, bits/s (Waldbusser 1995).

$\Delta t-$ laiko tarpas. $\Delta t=60 \mathrm{~s}$.

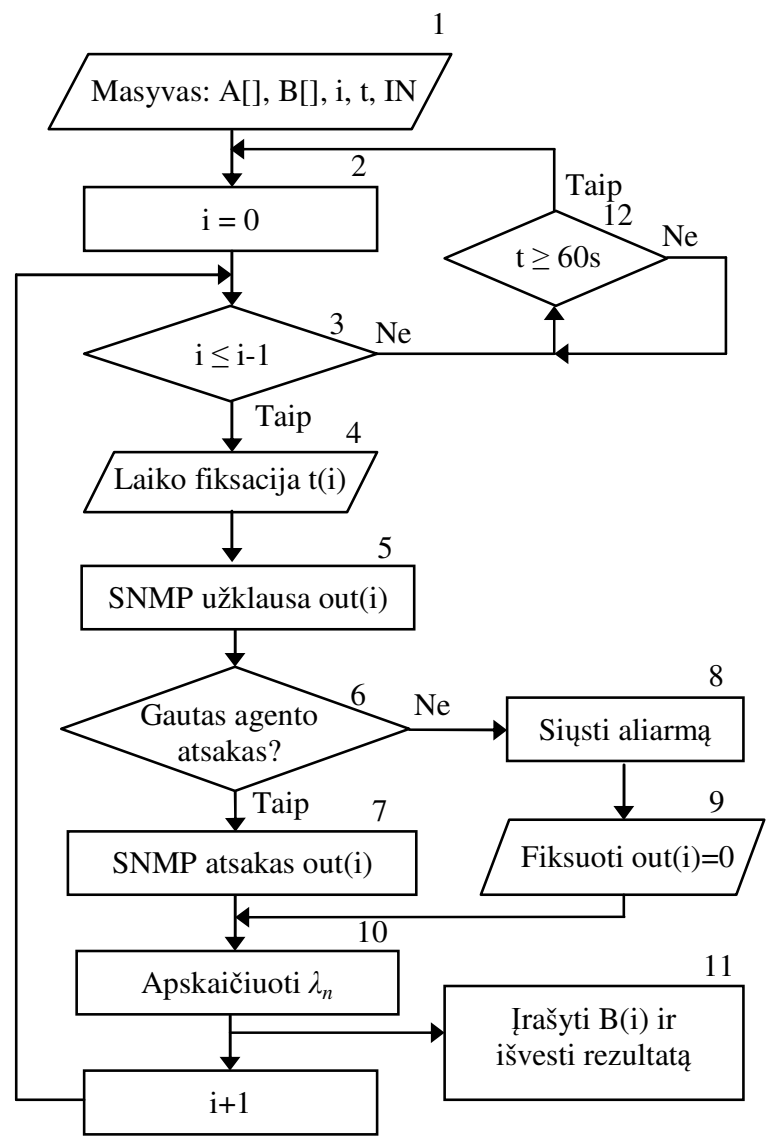

3.2 pav. Kritinių interneto tinklo elementų stebėsenos algoritmas

Fig. 3.2. Critical internet network elements monitoring algorythm

Interneto tinklo infrastruktūros kritinių mazgų stebėsenos algoritmo (3.2 pav.) igyvendinimas realizuotas pseudo kodo algoritmu. Pseudo kodo realizacija realiai stebėsenai atlikti pateikiama 3.3 paveiksle ir yra tinkama programiniam realizavimui. 
SNMP agentai gali būti programiškai konfigūruojami kas ịgalina nustatyti aliarmo žinučių siuntimą stebèsenos sistemai ne tik visiško linijos gedimo atveju, bet ir esant kritiniam linijos apkrovimui, t. y. esant sąlygai $\lambda_{n} \geq 0,8$. Tokiu būdu stebėsenos funkcija atliekama dar operatyviau.

1 t, id_A, out $\in \mathrm{B}[]$

$\mathrm{i} \in[0, \mathrm{n}-1]$;

read ID, IP_address $\in \mathrm{A}[]$;

2 set $\mathrm{i}=0$;

3 for each ID $\in \mathrm{A}[\mathrm{i}]$ do

$4 \quad$ fix local system time $t(i)$;

$5 \quad$ send SNMP request IP_address $\in \mathrm{A}[\mathrm{i}]$;

$6 \quad$ if IP_address $\in \mathrm{A}[\mathrm{i}]$ responded then;

$7 \quad$ get out(i);

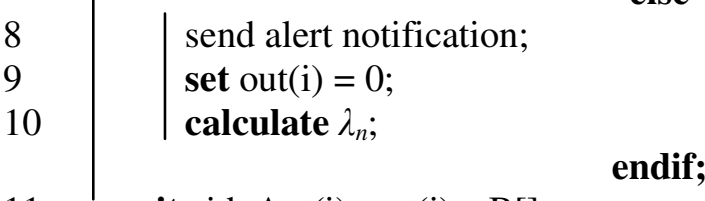

11 write id_A, t(i), out(i) $\in \mathrm{B}[]$;

12 wait $60 \mathrm{~s}$.

end;

return.

3.3 pav. Kritinių interneto tinklo elementų stebėsenos pseudo kodo algoritmo realizacija

Fig. 3.3. Critical internet network elements monitoring pseido-code algorythm

\subsection{Trečiojo skyriaus išvados}

1. Interneto tinklo infrastruktūros patikimumui ypatingą svarbą turi tarptinklinių sujungimų mazgai ir ryšio linijos. Sudaryta metrika leidžianti nustatyti kritinius regiono interneto tinklo elementus: kritinius ir $\eta$ - kritinius mazgus bei kritines ir $\kappa$-kritines linijas.

2. Sudarytą metriką pritaikius Lietuvos interneto tinklo infrastruktūrai:

- identifikuoti 4 kritiniai mazgai $\left(V_{c}\right)$;

- $\quad$ nustatyti $3 \eta$ - kritiniai mazgai, tenkinantys sąlygą $\eta_{i} \geq 0,1$;

- nustatytos 26 kritinès linijos ir 2 IPT, kurių tarpe yra $\kappa$ - kritinès linijos, tenkinančios sąlygą $\eta_{A S} \geq 0,9$.

3. Nacionalinio interneto tinklo infrastruktūroje yra apibrèžtas skaičius jungčių ir mazgų, nuo kurių priklauso bendras tinklo junglumas ir atitinkamai 
tinklo patikimumas. Konkretus kritinių mazgų ir jungčių identifikavimas nurodo tinklo pažeidžiamumus. Atitinkamai tikslingas tokių mazgų ir jungčių mažinimas (tinklo junglumo didinimas) suponuoja interneto tinklo patikimumo stiprinimą.

4. Irodyta, kad kritinių tinklo elementų stebėsena įmanoma SNMP protokolo pagrindu naudojant detektorius tinklo kritiniuose mazguose ir bendrą stebėsenos sistemą. Sudarytas tinklo stebėsenos algoritmas ir jo realizacijos kodas. Sudarytas stebėsenos modelis leidžia realiu laiku centralizuotai vertinti regiono interneto tinklo būseną, analizuoti tinklo veiklos sutrikimus. 


\section{Kibernetinių atakų ịtaka interneto funkcionalumui}

Tyrimo tikslas yra parengti modelị, kuriuo siekiama ịvertinti kibernetinių atakų poveiki Lietuvos interneto tinklo infrastruktūrai ir nustatyti labiausiai pažeidžiamus mazgus ir linijas tinkle. Sudarytas virtualus Lietuvos interneto tinklo modelis bei paruošti ir išbandyti skirtingi kibernetinių atakų scenarijai. Atliekant bandymus generuojant duomenų srautų ataką iš tarptautinių AS nukreiptą i Lietuvos tinklo infrastruktūrą, nustatyti 3 AS (mazgai) ir 4 jungiamosios linijos, kurios pasieké galimybių ribas. Kiti atakų scenarijai nukreipti i atskirus tinklo infrastruktūros mazgus lèmè, kad tinklas sugebejjo akumuliuoti duomenų srautus.

Skyriaus tematika publikuoti du autoriaus straipsniai (Kajackas, Rainys 2011; Kajackas, Rainys, Aputis 2011).

\subsection{Kibernetinių atakų analizè}

Elektroninių ryšių tinklų ir informacijos saugumo incidentas (kibernetinè ataka) apibūdinamas kaip ịvykis, veiksmas ar neveikimas, kuris sukelia ar gali sukelti neteisètą prisijungimą ar sudaryti sąlygas neteisètai prisijungti prie informacinès sistemos ar elektroninių ryšių tinklo, sutrikdyti ar pakeisti (įskaitant valdymo 
perėmimą) informacinès sistemos ar elektroninių ryšių tinklo veikimą, sunaikinti, sugadinti, ištrinti ar pakeisti elektroninius duomenis, panaikinti ar apriboti galimybę naudotis elektroniniais duomenimis, taip pat sudaryti sąlygas pasisavinti ar kitaip panaudoti neviešus elektroninius duomenis tokios teisès neturintiems asmenims. Yra duomenu apie didelio masto kibernetines atakas, kurios turejo ịtakos interneto tinklo veiklai. 2007 metais buvo surengta didelio masto kibernetinė ataka prieš Estijos informacines sistemas. Atakos metu buvo pažeisti bankų, ịvairių ministerijų, vyriausybès, bei kiti svarbūs Estijos internetiniai tinklalapiai. Buvo nustatyta, kad išpuolio metu surengta 128 PAAA atakos, iš jų 115 interneto kontrolès žinučiu protokolas (ICMP) protokolo, 4 TCP/IP ir 9 kiti kanalų srautu perkrovos (Nazario 2010). Atakos metu buvo pažeista didelè Estijos interneto tinklo dalis. 2008 metais buvo surengta panašaus pobūdžio kibernetiné ataka Gruzijoje. Ataką sudaré taip pat PAAA atakos, kurių pasireiškimo pobūdis buvo analogiškas Estijos atvejui (Nazario 2010).

Pagal minètų kibernetinių atakų nukreiptų i interneto tinklą pavyzdžių analizę ir darbų (Mirkovic 2004, Chandramouli 2009) rezultatus, tikslinga išskirti tris (BGP, TCP ir DNS) tinklo protokolus, kuriuos naudojant atakų poveikis tinklui yra didžiausias.

BGP protokolas yra svarbiausias maršruto parinkimo protokolas interneto tinkle, skirtas keistis maršruto parinkimo informacija tarp autonominių sistemų (Kozierok 2005, Mahajan 2002). Pagrindiniai šio protokolo saugumo trūkumai yra transporto mechanizme bei griežtos autentifikacijos nebuvimas. Dažnu atveju operacinèse sistemose arba tinklo valdymo ịrenginiuose, palaikančiuose BGP, nèra naudojama autentifikacija, taip pat pasitaiko, kad slaptažodžiai tinkle yra siunčiami nešifruoti. Kadangi BGP protokolas naudoja TCP protokolą BGP sesijoms užmegzti, BGP sesijos tampa pažeidžiamos dèl TCP protokolo spragų. Išnaudojus šias saugumo spragas atakos rengejai gali manipuliuoti interneto tinkle esančiu BGP srautu. BGP srautas einantis ị kitą tinklą gali būti nutrauktas arba gali būti nukreiptas ị kitą norimą tinklą, kad būtų galima išgauti ir pasisavinti siunčiamą informaciją.

Kadangi BGP protokolo maršrutizavimo lentelių duomenų tikrumo patikrinimo mechanizmų nèra, grèsmès internete pasireiškia sekančiai:

- klaidinga kelio informacija, apsikeičiant maršrutizavimo lentelemis tarp AS, greitai išplinta tinkle. Didesnis skaičius klaidų gali sutrikdyti tinklo veiklą (Hall 2011);

- nenaudojami IP adresacijos blokai panaudojami AS neturint tam teisès;

- IP adresacijos bloko pasiekiamumas nurodomas fiktyviai, siekiant perimti duomenų srautą.

Transporto kontrolès protokolas (TCP) protokolas skirtas duomenų srautų kontroliavimui kompiuteriniuose tinkluose. TCP yra svarbiausias protokolas Internetinių protokolų rinkinyje TCP/IP. Sudarant sujungimą tarp dviejų sistemų 
TCP protokolas naudoja „Three way handshake“ metodą ryšio sesijoms užmegzti (Kozierok 2005). Pavyzdžiui, kibernetinès atakos metu yra siunčiama didelis skaičius SYN ir neatsakomo SYN-ACK tipo pranešimų. Tokių būdų sistemos resursai yra apkraunami iki ribų ir sistemos funkcionavimas blokuojamas.

Domenų vardų sistema (DNS) yra hierarchinè įvardijimo sistema skirta kompiuteriams ar kitoms sistemoms prijungtoms prie interneto ar privataus tinklo. Svarbiausia DNS funkcija, tai paversti skaitomus domenu vardus ị skaitmeninị atitikmenį, kuris susijęs su tinklo ịrangą. Pasaulyje yra 13 pagrindinių DNS serverių, jie sudaro visų serverių hierarchijos viršūnę ir be jų internetas tiesiog negalètų funkcionuoti. Kibernetinès atakos metu yra stengiamas apkrauti DNS serverių resursus taip, kad jų funkcionavimas nutrūktų. Sutrikus DNS serverių darbui daugelis sistemų taptų nepasiekiamos, nes nebūtų teikiama informacija apie sistemų domenų vardus.

\subsection{Metodologija}

Tyrimu siekiama prognozuoti hipotetinès kibernetinès atakos įtaką Lietuvos interneto tinklo infrastruktūrai, bei nustatyti silpnąsias vietas tinklo infrastruktūroje. Kuriama eksperimento metrika orientuota i 3 skyriuje nagrinètus tinklo kritinius elementus, t. y. siekiama ịvertinti kaip kibernetinių atakų srautai ir tinklo perkrovos (Pavilanskas 2010) ịtakos tinklo elementus ir konkrečiai kritinius elementus.

Siekiant nustatyti koks galètų būti kibernetinių atakų poveikis Lietuvos interneto tinklo infrastruktūros funkcionalumui, reikalinga išspręsti sekančius uždavinius:

i. sudaryti (simuliuoti) virtualią tinklo topologijos schemą pagal realius duomenis apie tinklo charakteristikas;

ii. sukurti ir išmėginti virtualiame tinkle hipotetinių kibernetinių atakų scenarijus, ịvertinti įtaką ir pasekmes.

Tyrimų objektas yra regiono interneto infrastruktūra, t. y. grafas iš AS, tarptautinių tinklo teikèjų AS bei tarptinklinių tranzitinès ir lygiaverčių mainų tipo sujungimų (4.1 pav.). Ivvertinus kitų darbų pavyzdžius (Kulikovs 2009, Kajackas 2007), tinklo modeliavimui pasirenkamas OPNET Modeler programų paketas. OPNET Modeler tinklo simuliacijos uždaviniui tinka, nes programa yra skirta projektuoti ir analizuoti ịvairaus tipo telekomunikacijų tinklus, jų mazgus ir linijas, bibliotekos leidžia pasirinkti ịvairias technologijas.

Daroma prielaida, kad interneto tinklas ar jo dalis gali būti pažeista kibernetinès atakos. Generuojamos atakos charakteristikos parenkamos atsižvelgiant $\mathfrak{i}$ jos ịtaką tinklo infrastruktūrai (4.1 skyriaus analizè). Realizuojama kuriant didesnius nei ịprasta duomenų srautus iš vienos ar kelèto AS potinklių, imituojant PAAA atakas arba įrenginių BGP protokolo konfigūracijos pakeitimas imituo- 
jant atsitiktinius gedimus ir konfigūravimo klaidas. Formuluojami ir eksperimentiškai tikrinami šie scenarijai:

1. dirbtinis duomenų srauto generavimas iš tarptautinių tinklo teikèjų AS ị Lietuvos interneto infrastruktūrą;

2. pagrindinio tranzitinès tipo tarptinklinių sujungimų mazgo gedimas;

3. pagrindinio lygiaverčių mainų tipo tarptinklinių sujungimų mazgo gedimas.

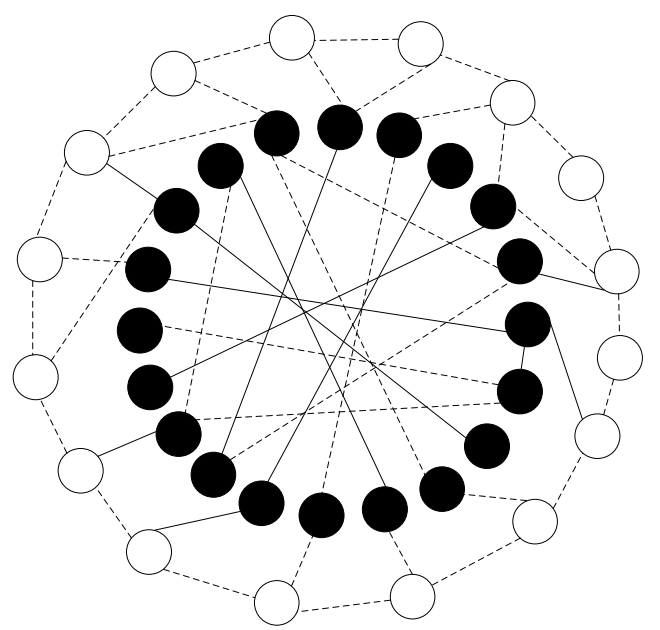

4.1 pav. Regiono interneto tinklo grafas: juodi mazgai yra regiono AS; balti - tarptautinès AS; lygiaverčių mainų sujungimai - punktyrinè linija; tranzitinès -linija

Fig. 4.1. Graph of the state Internet network: national AS represented in black nodes; international AS in white; peering interconnections type - dotted lines; tranzitinès - solid lines Structure of network visualization data base

\subsection{Tyrimo rezultatai}

Realizuojant pirmaji metrikos etapą, regiono interneto tinklas sumodeliuotas OPNET iš 40 regioninių AS, 17 tarptautinių tinklo teikèjų AS, 548 tarptinklinių sujungimų, tame tarpe 424 lygiaverčių mainų ir 124 tranzitinès. Duomenys tinklo modeliui naudoti iš 2 skyriaus darbo rezultatų bei juos atnaujinus pagal laike pasikeitusią topologiją. Lyginant su periodu kai vykdyta topologijos analizè, mazgų ir jungčių skaičius išaugo. Atitinkamai ryšių grafas taip pat išsiplètė.

Maršruto parinkimo duomenų keitimuisi tarp autonominių sistemų buvo panaudotas BGP protokolas, nes šis protokolas šiuo metu yra pagrindinis maršruto parinkimo protokolas naudojamas Internete. Autonominę sistemą OPNET Modeler terpejje atitiko vienas Ethernet technologijos maršruto parinktuvas palaikantys BGP protokolą. Autonominių sistemų apjungimui tinkle buvo panau- 
dotos 10GBaseX ir 1000BaseX technologijos. Technologijų tipas buvo pasirinktas atsižvelgiant $\mathfrak{i}$ tai kokia pralaida yra naudojama tarp realių AS Lietuvos interneto infrastruktūroje.

Sumodeliuotame Lietuvos interneto tinkle buvo sukurti trys skirtingi duomenų srautai. Pagrindinis duomenų srautas buvo kuriamas Lietuvos tinklo viduje, taip pat buvo sukurtas duomenų srautas einantis iš Lietuvos tinklų ị tarptautinius AS ir duomenų srautas iš tarptautinių tinklų einantis į Lietuvos AS. Tinklo modelyje duomenu srautams sukurti buvo naudojamas (FTP, HTTP, E-mail) paslaugos.

Dėl informacijos konfidencialumo modelyje esančių AS realūs pavadinimai yra užkoduoti, tačiau autoriui yra žinomi. AS yra priskiriami tam tikri numeriai. Taip pat nèra skelbiami užsienio šalių AS su kuriomis Lietuvos tinklai turi sujungimus.

Kibernetinès atakos tinklo modelyje buvo realizuojamos kuriant duomenu srautų pliūpsnius, imituojant PAAA atakas. Duomenų srautai buvo kuriami iš vienos ar kelètos autonominių sistemų potinklių. Kitas atakų realizavimo būdas buvos ịrenginių BGP protokolo konfigūracijos pakeitimas imituojant atsitiktinius gedimus ir konfigūravimo klaidas.

Virtualioje Lietuvos interneto tinklo infrastruktūroje buvo modeliuojamas iprastas tinklo darbas ir nustatytos ịprastos (neviršijant normalių duomenų srauto apimčių) tinklo darbo sąlygos. Tai leido nustatyti ribas nuo kurių reikia keisti ivesties vertes atakų imitavimui. Iprasto tinklo darbo metu buvo surinkti duomenys:

- Autonominių sistemų BGP maršrutų lentelès įrašai;

- Duomenų perdavimo linijų pralaidumas;

- Vartotojų paslaugų vélinimo laikai;

- BGP protokolo parametrai;

- Irangos CPU parametrai.

Pagal ịprasto tinklo darbo metu surinktų duomenų pakitimus buvo įvertinama kibernetinių atakų įtaka.

Lietuvos interneto infrastruktūra AS lygiu sumodeliuota pirmą kartą. realizacija OPNET ịrankiu pateita B priede.

\subsubsection{Srauto generavimo kibernetinè ataka}

Šio scenarijaus realizavime kibernetinè ataka vykdyta generuojant srautą i visas regiono AS (4.2 pav.). Simuliuojama situacija, kai tarptautinių ryšio kanalų pralaida maksimaliai išnaudota duomenų srautui. Atitinkamai regioninių AS tarptinkliniai sujungimai ịtakojami ir srautų pasiskirstymas tinkle sutrinka. Realiai toks scenarijus susidaro PAAA atakų atvejais, kai netipiškai dideliam srautui generuoti naudojami botnet tinklai (Juknius 2011). 
Sumodeliuotame tinkle imituojant normalų tinklo darbą ir papildomai simuliuojant kibernetinès atakos srautus, kompiuterinių resursų OPNET programai nepakanka arba skaičiavimų laikas yra nepatenkinamas. Todèl ịvedamas koeficientas skaičiavimų duomenims sumažinti visais lygiais vienodai.

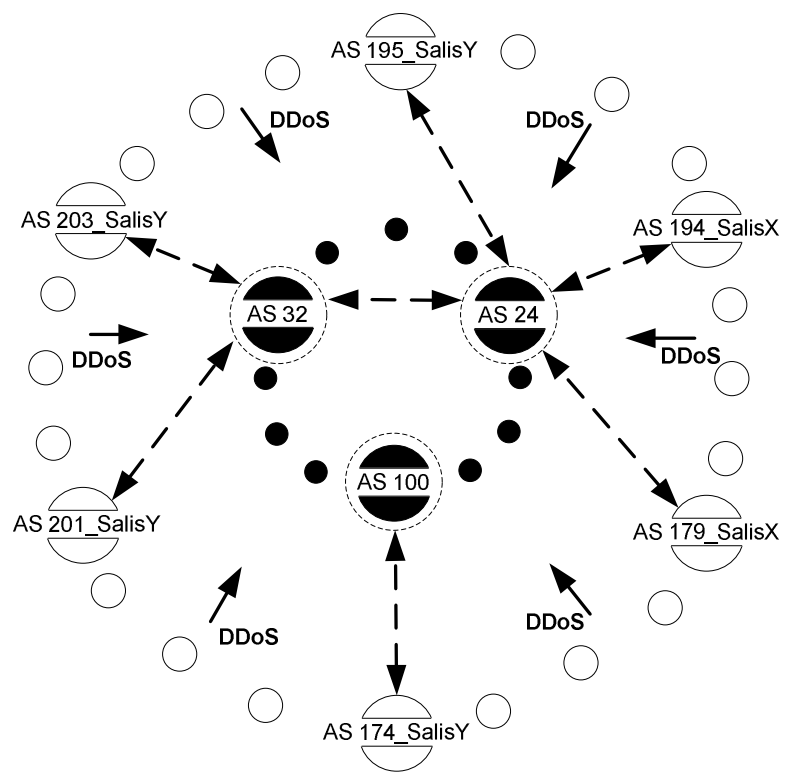

4.2 pav. Tinklo topologijos fragmentas iliustruojantis kibernetinę ataką (atakos vektorius - PAAA iš tarptautinių AS ị nacionalinị tinklą)

Fig. 4.2. Part of the network topology illustrating type of attack (attack vector represented by DDoS from international AS to the national AS infrastructure)

Pirmo scenarijaus eksperimento rezultatai parodè, kad PAAA simuliacija turejjo įtakos 3 AS (sąlyginiai numeriai 24, 32 ir 100). Virtualaus tinklo tarptinklinių sujungimų išdavoje šie mazgai akumuliavo didžiają dalị atakos srauto. AS (sąlyginiai numeriai 24,32 ir 100) jungiantys ryšiai skiriasi savo pralaidos ir maršrutizavimo parametrais, todèl atakos įtaka sujungimams nevienoda. Didžiausias srautų apkrovas gavusių linijų nustatymas leidžia identifikuoti atakos pažeidžiamas sritis tinklo infrastruktūroje.

İvertinus AS (sąlyginiai numeriai 24, 32 ir 100) sujungimų apkrovos matavimus nustatytos 4 linijos paveiktos atakos. Srautai šiose linijose pasiekè maksimalią pralaidą (4.3 pav.). Rezultate tai linijos gedimas. 4.3 pav. grafikas iliustruoja linijos, kurioje srautas buvo didžiausias, apkrovos kitimą. 20-ą scenarijaus eksperimento minutę srautas linijoje išaugo 3 kartus daugiau nei yra ịprastas linijos apkrovimas. Analogiški procesai užfiksuoti ir kitose trijose atakos pažeistose linijose. 


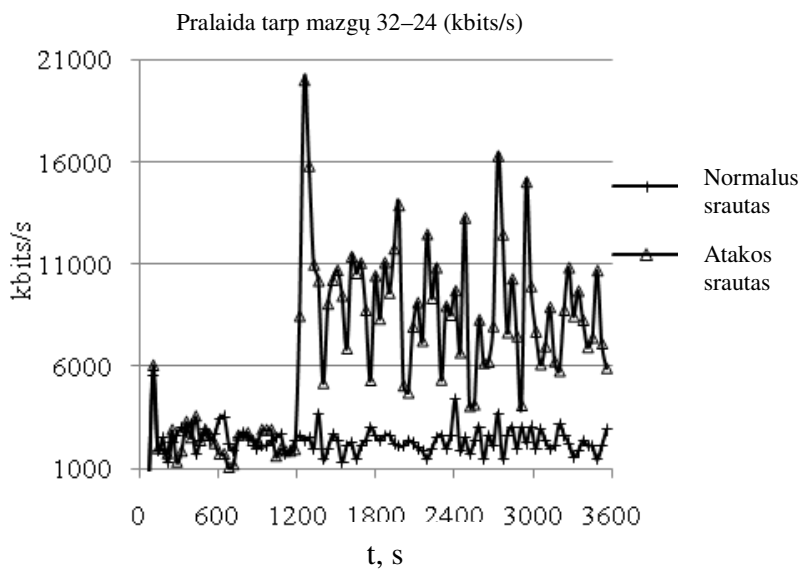

4.3 pav. Linijos pralaidos matavimo rezultatai vykstant $P A A A$ atakai (rezultatai icvertinus koeficienta $k=1000$ )

Fig. 4.3. Throughput measurement during the $D D o S$ attack scenario (results with set of coefficient $k=1000$ )

\subsubsection{Tranzitinio mazgo kibernetinè ataka}

Antrojo scenarijaus eksperimente pasirinktas tinklo mazgas (AS numeris 24), siekiant ịvertinti jo pažeidimo dèl kibernetinès atakos (mazgo gedimas tinkle dèl BGP konfigūracijos pažeidimo) įtaką tinklo darbui (4.4 pav.). Atakos tikslas buvo nutraukti duomenų perdavimą Lietuvos tinklams vieninteliu tiesioginiu tranzitiniu sujungimu jungiančiu AS Nr.24 su AS Nr.194 užsienyje. AS Nr.24 tinklo topologijoje turi didžiausią skaičių tranzitinès tipo tarptinklinių jungčių ir pagal 3 skyriaus tyrimus identifikuojamas kaip $V_{c}$.

Eksperimento metu, eliminavus tinklo mazgą, srautai tinkle persiskirstè. Maršrutizavimo lentelès pasikeitė duomenų srautus nukreipiant aplenkiant AS Nr.24. Regioninio tinklo srautai, atnaujinus maršrutizavimo lenteles, veikè.

Šis mazgas topologijoje turi tarptinklinius sujungimus su tarptautiniais AS, todèl kiti regioninio tinklo AS vartotojai ị tarptautinị internetą gali išeiti per kitas Tier-1 AS. Analogiškai srautai iš tarptautinių AS persiskirste ị kitas tarptautines AS, kad pasiekti regioninį tinklą apeinant AS Nr.24. To išdavoje išaugo apkrovos linijose. 4.5 paveiksle iliustruota linijos apkrovimas tarptinklinių sujungimų jungtyje su tarptautiniu AS. 20-ą scenarijaus eksperimento minutę srautas linijoje išaugo apytikriai 8 kartus daugiau nei yra ịprastas linijos apkrovimas (linijos gedimas). 


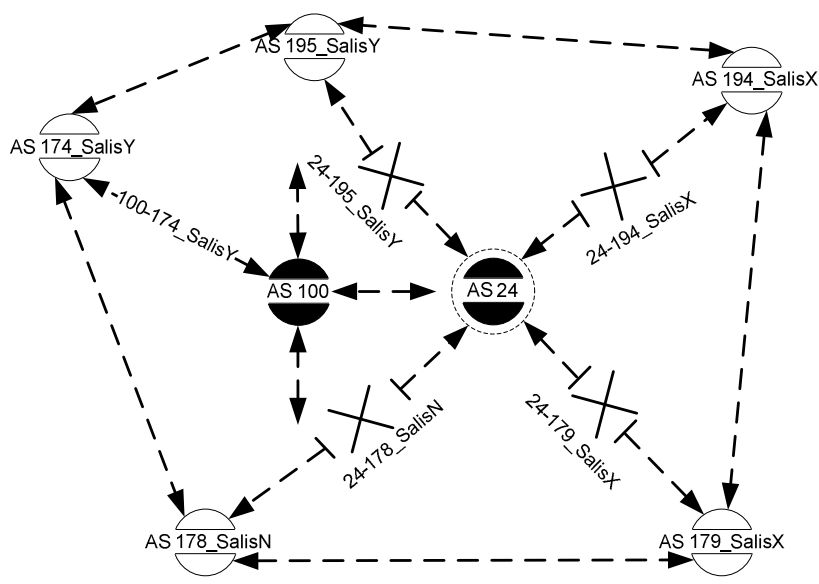

4.4 pav. Tinklo topologijos fragmentas iliustruojantis kibernetinę ataką (atakos vektorius - tranzitinès tarptinklinių sujungimų mazgo pažeidimas)

Fig. 4.4. Part of the network topology illustrating the attack on interconnections node (attack vector represented by broken node/lines)

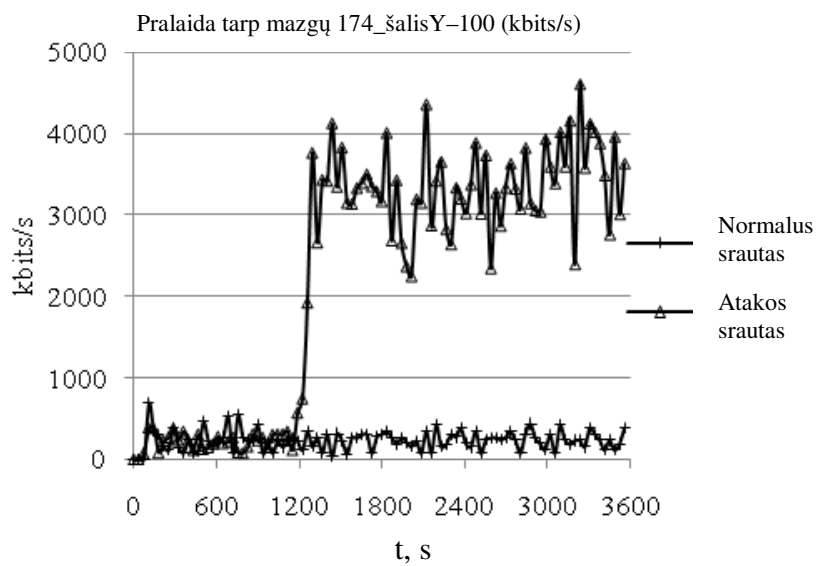

4.5 pav. Linijos pralaidos matavimo rezultatai vykstant tranzitinès mazgo atakai (rezultatai ịvertinus koeficientą $k=1000$ )

Fig. 4.5. Throughput measurement during the tranzitinès node attack scenario (results with set of coefficient $k=1000$ ) 


\subsubsection{Lygiaverčių mainų mazgo kibernetinè ataka}

Scenarijus realizuotas su prielaida, kad kibernetinès atakos pasekoje tarptinklinių lygiaverčių mainų sujungimų mazgas buvo pažeistas (realizacija analogiška 4.4 pav.). Dèl pakitusios BGP protokolo konfigūracijos duomenų perdavimas lygiaverčių mainų sujungimais buvo nutrauktas. Pagal tinklo topologijos tyrimus (žiūr. 3 sk.), Lietuvos interneto tinklo infrastruktūroje yra centrinis lygiaverčių mainų maršrutizavimo mazgas LMMM.

Scenarijaus eksperimento rezultate srautai eliminavus LMMM persiskirste $i$ tranzitinès sujungimų tinklą. Tranzitinès linijų apkrovos išaugo. Išanalizavus visus tinklo tranzitinius sujungimus pagal tai kiek kartų pakito apkrova, buvo nustatyti tranzito tipo sujungimai, kuriems teko didžiausia apkrova. 4.6 paveiksle pavaizduotas $42 \mathrm{AS}-4 \mathrm{AS}$ tranzito jungimo pralaidumo vidurkio grafikas. Šis sujungimas priklauso AS Nr.24, tai didžiausia Lietuvos interneto tinklo AS turinti 28 tranzito sujungimus. Pagal pateikta grafiką pastebima, kad 10 minutę sujungimo apkrova ženkliai padideja ir apkrova tampa tris kartus didesnè. Būtent šiam sujungimui teko didžiausia apkrova.

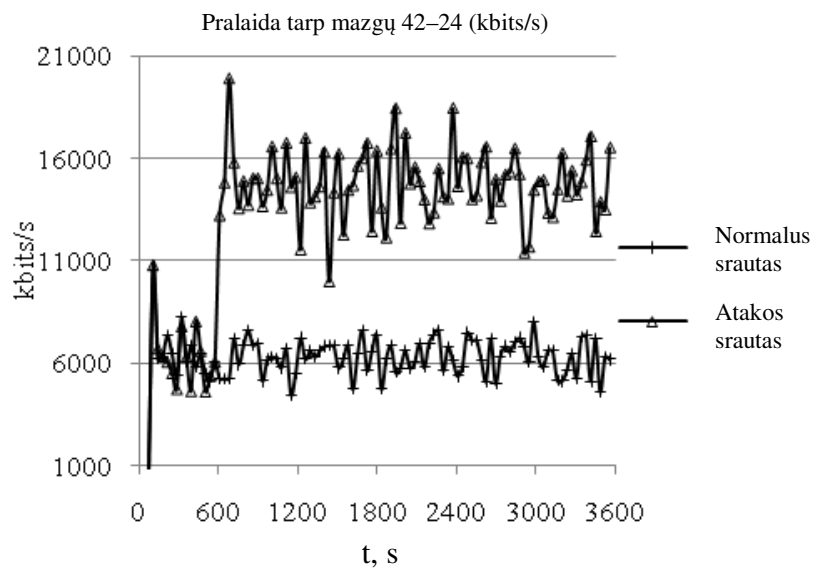

4.6 pav. Linijos pralaidos matavimo rezultatai vykstant lygiaverčių mainų mazgo atakai (rezultatai ịvertinus koeficientą $k=1000$ )

Fig. 4.6. Throughput measurement during the peering node attack scenario (results with set of coefficient $k=1000$ ) 


\subsection{Ketvirtojo skyriaus išvados}

1. Pasiūlytas metodas ịvertinti ir išmatuoti hipotetinių kibernetinių atakų ar mazgų gedimų ịtaką interneto infrastruktūros funkcionalumui. Eksperimentai pratęsia ir užtvirtina interneto tinklo topologijos ir tinklo infrastruktūros kritinių elementų tyrimus.

2. Sukurtas virtualus Lietuvos interneto tinklo modelis, kurio pagrindu, eksperimentiškai įvertinamas tinklo patikimumas naudojant kibernetinių atakų scenarijus.

3. Eksperimente, kurio kibernetinès atakos vektorius iš tarptautinių AS nukreiptas ị nacionalinị regiono tinklą, nustatyta:

- 3 AS (tinklo mazgai) ir 4 tarptinklinių sujungimu linijos patyrè maksimalias srautų apkrovas ir negalèjo funkcionuoti normaliu režimu;

- Šiose tinklo infrastruktūros vietose pirmiausia susidaro perkrovos ir interneto paslaugu teikimo trūkiai, dèl to faktiškai vartotojams neužtikrinama reikalinga kokybé;

- Eksperimento metu pažeistos AS ir linijos sutampa su 3 skyriuje teoriškai nustatytais kritiniais mazgais ir linijomis. Tai patvirtina teorinio modelio pagrịstumą.

4. Bandymuose, kurių kibernetinès atakos vektoriai nukreipti $\underset{i}{\text { tranzitinès ir }}$ lygiaverčių mainų tarptinklinių sujungimų mazgų pažeidimus, reikšmingų bendro tinklo funkcionalumo sutrikimu nepatyrè. Tinklo infrastruktūra perskirstė srautus taip, kad bendras tinklas išlikdavo funkcionalus. Šių scenarijų atvejais kibernetinès atakos reikšmingai pažeidè tik vieną ryšio liniją.

5. Tyrimo rezultatai naudingi prognozuojant realių kibernetinių atakų ịtaką regiono interneto tinklo infrastruktūrai. Sukurtas modelis naudingas modifikuojant Lietuvos interneto tinklo infrastruktūrą. 


\section{Interneto tinklo infrastruktūros patikimo stiprinimas}

Skyriuje formuluojamos priemonès regiono interneto tinklo infrastruktūros pati-

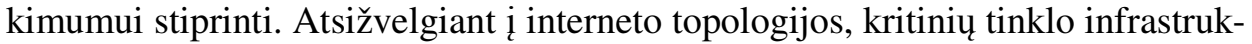
tūros elementų bei kibernetinių atakų simuliacijų tyrimų rezultatus, siūlomos išankstinio įspejjimo sistemos pritaikymo, tinklo topologijos balansavimo ir organizacinių priemonių visuma. Šių priemonių pritaikymas regiono tinklo infrastruktūros reguliavimo politikoje sudarys prielaidas užtikrinti regiono interneto tinklo veiklos patikimumą ir saugumą. Formuoja regiono interneto ateities vystymo gaires.

Skyriaus tematika paskelbtas vienas autoriaus straipsnis konferencijų medžiagoje (Rainys 2006; Kajackas, Rainys 2010; Kajackas, Rainys 2011).

\subsection{Prielaidos}

Interneto tinklas vystomas prisilaikant tinklo neutralumo principų. Interneto duomenų srautas skaidomas ị paketus, kurie iš siuntejjo gavejjui nukreipiami artimiausiu ir/ar greičiausiu keliu. Paketai tinkle yra lygiaverčiai; maršrutizatoriai ir kita tinklo įranga stengèsi juos kuo greičiau išsiųsti adresatui, neskirstydama, kuris yra svarbesnis (Watal 2011). Ekonomiškai visi perduoti duomenu paketai 
yra vienodos vertès. Laikoma, kad tinklo neutralumo principas yra sėkmingo interneto plètros fakto priežastis.

Išskyrus domenų vardų sistemą (DNS), interneto plètra tiesiogiai nèra įtakojama reguliavimo mechanizmų. Tačiau dèl išaugusios įtakos verslui, technologinių procesų valdymui, valstybės paslaugų teikimui bei vartotojų socialiniams santykiams, interneto tinklas tapo svarbiu resursu valstybės ir jos piliečiu gyvenimo kokybei. Be to, 4 skyriuje aprašyti eksperimentai demonstruoja riziką kylančią tinklo infrastruktūrai dèl kibernetinių atakų poveikio. Dẻl šių priežasčių absoliutaus interneto neutralumo prisilaikyti nepakanka. Reikalingas interneto reguliavimas arba tam tikras minimalių saugumo ir patikimumo reikalavimų užtikrinimas.

Internetas, analogiškai kitoms telekomunikacijų technologijoms kaip PSTN ir GSM, yra valstybės priežiūros ir reguliavimo objektas. Tačiau reguliavimo tarnyboms interneto tinklas kaip priežiūros objektas yra nauja sritis. Dar nèra pakankamai praktikos kaip užtikrinti interneto veiklos patikimumą ir kokybę. 2, 3 skyriuose pateiktos tinklo topologijos bei kritinių elementų analizès metrikos leidžia vertinti regioninio interneto tinklo infrastruktūros patikimumą. Tai laikytina kiekybiniu ir kokybiniu ịvertinimu. Be to, atsižvelgiant ị praktinių tyrimų rezultatus, kyla poreikis veiksmams ir priemonèms, kurios galètų kontroliuoti ir gerinti tinklo infrastruktūros patikimumą.

Tokių priemonių tikslas būtų sustiprinti regiono interneto tinklo infrastruktūros saugumą ir patikimumą, vykdant kritinių tinklo funkcijų priežiūrą ir stiprinimą. To neužtikrinus kyla interneto veiklos trikdžių rizika, kas gali iššaukti interneto nepasiekiamumą didelei grupei vartotojų, elektroninès valdžios paslaugų teikimo sutrikimus ir pan.

Ateities interneto architektūra taip pat yra svarbus aspektas nagrinèjant tinklo infrastruktūros patikimumo priemones. Interneto protokolas orientuotas $\mathfrak{i}$ duomenų perdavimą realizuojamą tarp galinių taškų - serverio ir vartotojo (endto-end principas). Jeigu tarkime vartotojas nr.1 atsisiunčia iš youtube serverio video failą, tame pačiame regione vartotojas nr.2 gali siųstis tą patị video failą atskirai ir netgi tuo pačiu laiko momentu. Tarkim tokių vartotojų regione vienu metu yra daug. Tas pats video atskirai siunčiamas daug kartų, todėl tinklo resursai (liniju pralaida) išnaudojami neoptimaliai. Paul S. 2010, 2011, FMIA-TT 2011, Allman M. 2007, Alduan 2010 darbuose konstruojama ateities interneto architektūra, kurios pagrindą sudaro turinys (media). Ji paremta dabartine hierarchine tinklo struktūra, kurioje ant dabartinès architektūros/topologijos (fizinis tinklas, serveriai su turiniu ir t. t.) atsiranda nauji tinklo architektūros lygiai 5.1 pav. Tai yra informacijos paieškos serverių ir paslaugų bei informacijos turinio paskirstymo serverių ir paslaugų lygiai. Tokios architektūros tinklo topologijos realizavimas bus ženkliai sudètingesnis, todèl reikia įvertinti tai, kad tinklo topo- 
logijos tobulinimas, jos saugumo ir patikimumo stiprinimas, atsižvelgtų i ateities architektūros pokyčius.

Veikia visa eilè mokslo projektų ruošiant bazę ateities interneto plètrai. Tokių projektų tikslai yra viso globalaus tinklo pokyčių planavimas. Tačiau priemonių regiono ar valstybės suformuoto interneto tinklo (globalaus interneto kontekste tai būtų tik potinklis) saugumui, vientisumui ir kokybei užtikrinti rengimas yra atskiras ir mažai nagrinètas mokslo darbuose klausimas.

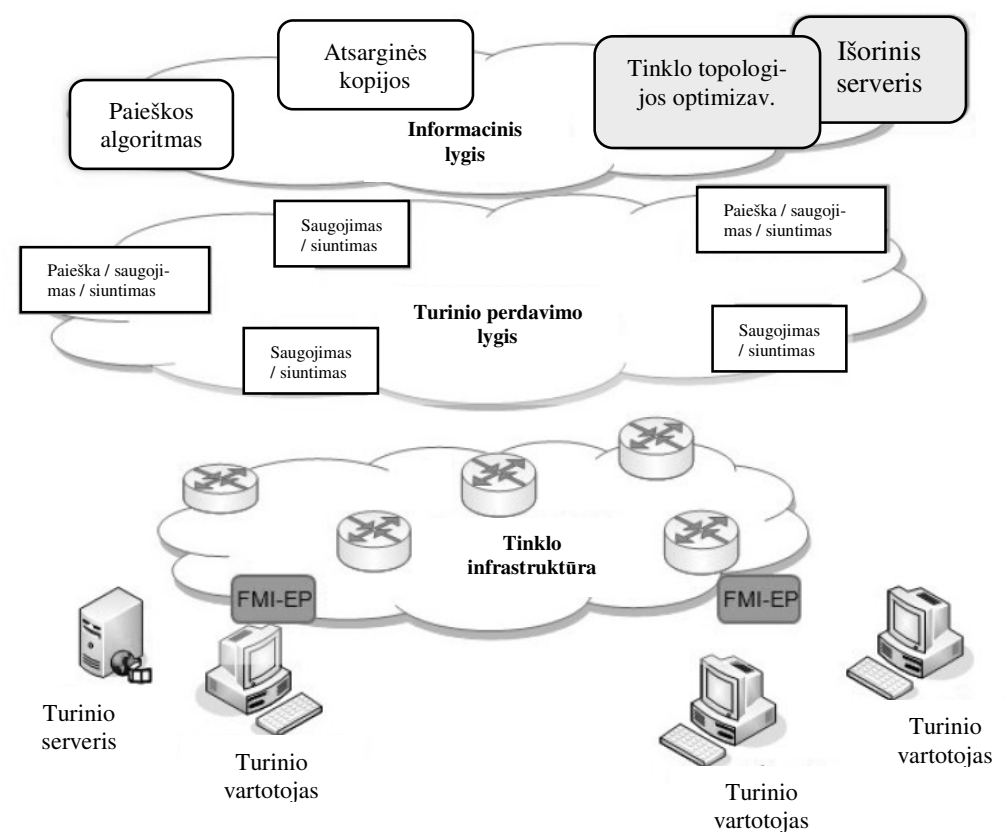

5.1 pav. Ateities media interneto architektūra (Paul 2010)

Fig. 5.1. Future Media Internet network architecture

\subsection{Išankstinio įspèjimo sistema}

Išankstinio įspejjimo sistemos (IIS) naudojamos ir vystomos tokiose srityse kaip ịspejjimai apie gamtos stichijas, cunamius ar žemès drebejjimus. IIS aliarmai skirti îspèti apie galimas nelaimes, imtis veiksmų nuostolius ir sugriovimams sumažinti (Grasso 2007). Tokios IIS pagrindinis principas yra sensorių, matuojančių, pavyzdžiui, žemės virpesius, signalai. Kritinè masė suveikusių sensorių iššaukia aliarmą. Šis principas gali būti panaudoti kuriant interneto tinklo infrastruktūros IIS. Tačiau internetui tik sensorių sistemos nepakanka arba ji negalès būti pakankamai veiksni. 
Regiono interneto tinklas yra sudètinga, stochastiškai sujungtų potinklių sistema. Juose veikia skirtinga tinklo ir srautų maršrutizavimo įranga, skirtingi protokolai (IP, BGP, SNMP, HTTP ir kita). Bendra tokio komplikuoto tinklo kibernetinio saugumo situacija nėra žinoma. Be to, kaip jau buvo aptarta 1 skyriuje, auga saugumo incidentų/gedimų skaičius tinkle, kibernetinès atakos tapo kompleksinėmis, o jų žala tinklo infrastruktūrai išaugo taip pat. Kad ịvertinti kibernetinio saugumo lygị, egzistuojančias grèsmes, kylančias kibernetines atakas, naudojamos IIS. IIS padeda aptikti grèsmes kaip galima anksčiau, išvengti ar sumažinti nuostolius, valdyti rizikas.

IIS naudojamos IPT savo tinklų apsaugai, kuri dažniausiai yra paremta paketų analize kibernetinių atakų prevencijai. Tačiau vertinant regiono tinklo aspektu, IIS realizacija yra sudètingesnè. Tam įtakos turi dèl tarptinklinių sujungimų esantys dideli ir nestabilūs duomenų srautai, kurių duomenų paketų analizei reikètų sudètingos IIS. Tokiu atveju IIS dar ir įneštų nepriimtiną duomenų perdavimo vẻlinimą.

Vertinant regiono tinklo apimtyje, kibernetinių atakų skaičius ir jų tipų variacija yra dideli. Taip pat reikia ịvertinti besikeičiančią ateities interneto architektūrą: išaugęs ịrenginių prijungtų prie tinklo skaičius, išplèsta IP adresacija (IPv6 protokolas), debesų technologijos ir išaugęs perduodamų duomenų kiekis. Tradicinès IIS negali efektyviai veikti šių faktorių aplinkoje (Golling 2011), todèl regiono interneto tinklo IIS architektūra turi būti sukurta naujai.

\subsubsection{Išankstinio įspèjimo sistemos analizè}

Dažniausiai sutinkamas IIS realizavimo variantas yra naudojant įsibrovimo aptikimo sistemą IDS. Naudojamos kelios pagrindinès IDS technikos: nesuderintų veiksmų aptikimas, anomalijų aptikimas arba abiejų kombinacijos (Golling 2011, Ando 2007).

Pirmuoju variantu IDS realizuojama remiantis signatūromis. Signatūrą sudaro iš anksto žinomų informacinès sistemos programų nesankcionuotų veiksmų požymių duomenų bazè. Tai gali būti kenksmingo programinio kodo pavyzdžiai, nepriimtinų procesų aprašai ir pan. Duomenų srautas yra tikrinamas ir lyginamas su signatūromis. Sutapimo atvejų generuojamas įspejjimas. Interneto tinkluose duomenų srautas yra per didelis, kad IDS efektyviai veiktų nesukeliant vẻlinimo, todèl dažai naudojama ne viso paketo turinio, o tik duomenų paketų antraščių tikrinimas.

Anomalijų aptikimo IDS sistemos lygina procesus tinklo įrenginiuose ir (ar) informacineje sistemoje su normaliuoju sistemos veiklos modeliu. Esamos tinklo duomenų srautų charakteristikos matuojamos ir lyginamos su aprašytais normalios veiklos požymiais (failų tipai, jų dydžiai, srautų apimtys per laiko matą ir pan.). Neatitikimai ar nestandartinè sistemos veikla indikuojami kaip anomali- 
jos. Pažangiausiose šio tipo IDS panaudojamos save apsimokančių mašinų technikos su evoliuciniais algoritmais ir neuroniniais tinklais. Problemų kyla jeigu naudojama duomenų bazè su per daug ,griežtomis“ charakteristikomis, anomalijų detektavimo IDS generuoja didelị skaičių klaidingų įspejjimų ir atvirkščiai.

Vertinant uždavinį sudaryti IIS skirtą regiono interneto tinklui, minèti IDS sprendimai negali tinkamai atlikti savo funkcijų:

a) duomenų srauto analizė gali aptikti, pavyzdžiui, tinklo perimetro skenavimo bandymus ar kenksmingą programinị kodą, nes jis būna tipinis (yra žinomas tokio kodo branduolys). Tačiau tikslinių atakų ar ịsilaužimo į konkretų tinklo infrastruktūros elementą detektuoti IDS tiksliai nesugeba (Shimoda 2007);

b) IDS veikla dažniausiai remiasi duomenų paketų analize, tačiau interneto tinkle duomenų srautai yra per dideli apdoroti IDS. Reikalingi duomenų buferiavimo metodai, o tai yra ekonomiškai neefektyvu dèl didelès didelių investicijų fizinei įrangai poreikio (Dharmapurikar 2003);

c) IDS sistemos yra ribotos ir nelanksčios, nes paprastai naudoja tik $\log$ ir flow failus bei duomenų paketų antraščių analizę (Wang 2004). Be to, kriptografiškai koduojant siunčiamus duomenis (pavyzdžiui, HTTPS protokole) - IDS savo funkcijos atlikti negali.

Darytina išvada, kad aprašytam uždaviniui atlikti, reikalingas naujo tipo arba kombinuotos IIS sprendimas.

\subsubsection{Išankstinio įspèjimo sistemos sprendimas}

IIS keliami uždaviniai:

a) IIS skirta veikti regiono interneto tinkle, sudarytame iš apjungtų potinklių ir AS. IIS generuojami ịspejjimo pranešimai (aliarmo signalai) taip pat turi būti aktualūs regiono interneto tinklo apimtyje;

b) kadangi regiono tinkle esančius potinklius valdo skirtingi operatoriai, tiesioginè intervencija, duomenų srautų perėmimas ir analizè, negalimas. Šaliai, ne tinklo savininkei, srautas yra neprieinamas, todèl aptartos standartinès IDS sistemos netinka;

c) siekiant tikslumo bei klaidingų pranešimų mažèjimo, IIS turi analizuoti ir sisteminti informaciją iš įvairių šaltinių susijusių su tinklo būsenos stebejjimu bei grèsmių tinklo infrastruktūros saugumui.

IIS koncepcijos kūrimui 5.2 pav. pasinaudota sprendimais aprašytais 1, 3, 4 skyriuose (Rainys 2006; Kajackas, Rainys 2010; Kajackas, Rainys 2011). Schemos viršutinejje dalyje yra tinklų infrastruktūra ir objektai, kurie generuoja informaciją IIS veiklai. Tai yra duomenų generavimo lygis. Jame egzistuoja automatinis techninės informacijos generavimas iš sensorių. Taip pat subjektai, kurie teikia pranešimus apie įvykusị incidento faktą bei pažeidžiamumų tyrimų laboratorijų informacijos duomenų bazès. Šioje vietoje ịvedama nauja, darbe nenagri- 
nèta, informacijos rūšis - IS ir jų taikomujų programų pažeidžiamumai. Egzistuoja didelis skaičius tokių duomenų bazių. Jos yra uždaros (specifinès) arba viešai prieinamos. Kadangi aptinkamų IS pažeidžiamumų programose bei tinklo ịrangoje yra daug, duomenų bazių įrašai kategorizuojami pagal operacinių sistemų tipą, ịrangos gamintoją ir pan. (Sufatrio 2004). Pažeidžiamumo įrašas paprastai turi savyje pažeidžiamos sistemos vietos aprašą, vertinimą dèl pasekmių, kurias gali sukelti piktavališkas pažeidžiamumo išnaudojimas ir egzistuojančios priemonès pažeidžiamumo pašalinimui.

Duomenų analizès lygis skirtas informacijos surinkimui ir analizei. SNMP stebėsenos sistema apdoroja duomenis iš sensorių esančių kritiniuose tinklo infrastruktūros elementuose. Sistemos veikimo principai aprašyti 3 skyriuje. Šiame etape analizuojama informacija parodo tinklo gedimus, srautų perdavimo sutrikimus. Tokios informacijos pagrindu turètų būti ieškoma tinklo gedimo priežasčių, ji galètų būti koreliuojama su informacija iš kitų šaltinių tam, kad identifikuoti priežastis sukeliančias gedimus tinkle.

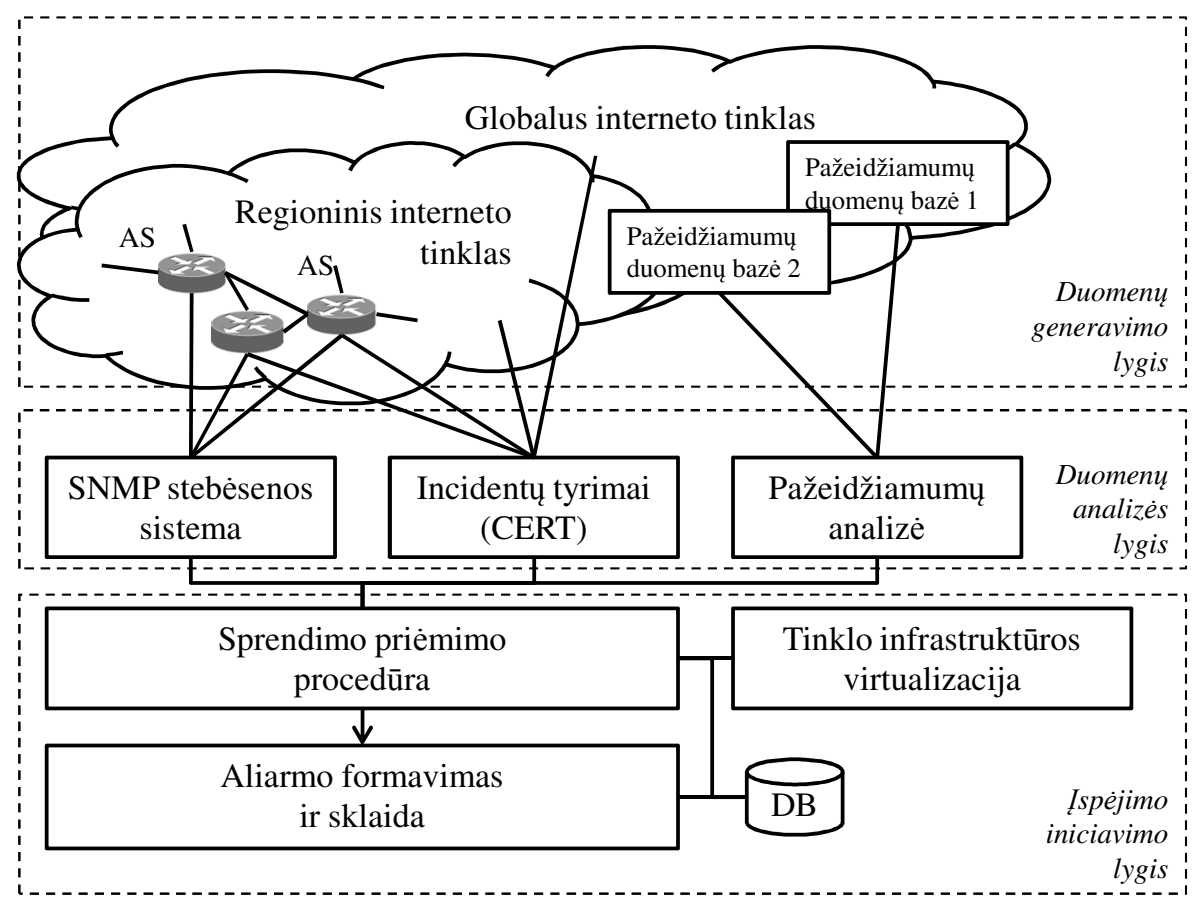

5.2 pav. IIS sistemos koncepcija (prototipas)

Fig. 5.2. Conceptual implementation of early warning system 
Kitas IIS informacijos šaltinis - CERT, aptartas 1 skyriuje. CERT incidentų tyrimai vykdomi pagal AS operatorių pranešimus arba iš honeypot tipo sensorių. Incidentu poveikis tinklo infrastruktūrai gali skirtis, todèl šioje vietoje analizuojama ar incidentas (pavyzdžiui, naujas kompiuterinis virusas) gali išplisti ị kitas AS ir sukelti didelio skaičiaus IS veiklos sutrikimus.

Pažeidžiamumų analizès objekte yra svarbu nustatymai, pagal kuriuos analizuojami pažeidžiamumai susiję su ịrenginiais ir programomis naudojamomis regioninio interneto tinklo infrastruktūroje. Nustačius susijusius pažeidžiamumus, vertinama galima jų įtaka tinklo infrastruktūrai ar kibernetinių atakų realizavimo galimybès.

İspejjimo iniciavimo lygyje analizuojama informacija iš aukštesnio lygmens objektų ir priimamas sprendimas(ai) dèl ịspèjimo reikalingumo. Sprendimas dèl ispẻjimo formavimo gali būti priimtas gaunant informaciją iš vieno šaltinio arba informacija iš kelių šaltinių koreliuojama ieškant ryšio(ių) tarp jų. Pavyzdžiui, esant informacijai apie pažeidžiamumą maršrutizavimo ịrangoje ir duomenims iš CERT apie įvykusius incidentus ir (ar) duomenims iš stebèsenos sistemos apie gedimus tarptinkliniuose sujungimuose, priimamas sprendimas dèl aliarmo iniciavimo. Kad ịspèjimo formavimo procesas būtų efektyvus, svarbu, kad informacija iš aukštesnio lygmens būtų pateikta kaip galima greičiau.

Sprendimo prièmimo objekto tikslas yra, pagal informaciją iš trijų objektų (duomenų analizès lygis), ịvertinti tikimybę îvykti ịvykiui $S$, kuris turès neigiamų pasekmių tinklo infrastruktūrai. Nustatoma, kad sprendimas dèl aliarmo iniciavimo įvyks kai bus viršytas kritinis informacijos apie įvykio $S$ tikimybę $S^{\prime}(t)$ lygis $a$.

Tikimybès $S^{\prime}(t)$ vertinime atsiranda neteisingo sprendimo (klaidos) $\varepsilon(t)$ tikimybè (Grasso 2007). Gali susidaryti dviejų rūšių klaidos: neįvykęs aliarmas $\varepsilon_{n a}(t)$, kai sprendimas dèl ịspejjimo formavimo nebuvo priimtas, tačiau pagal pasekmes tinklo infrastruktūrai aliarmas buvo reikalingas; klaidingas aliarmas $\varepsilon_{k a}(t)$, kai aliarmas buvo realizuotas, tačiau situacija dėl neigiamų pasekmių tinklo infrastruktūroje nesusiformavo. Sprendimo prièmimo objektas, ịvertinantis tikimybės neapibrèžtumą ir priimtų sprendimų pasekmes, turètų sumažinti $\varepsilon_{n a}(t)$ ir $\varepsilon_{k a}(t)$ aliarmų ịvykius. Nuo informacijos patenkančios į objektą kiekio ir kokybès keičiasi tikimybès neapibrèžtumas ir $\varepsilon(t)$.

$$
\begin{aligned}
& P_{k a}(t)=P\left[S \leq a \mid S^{\prime}(t)\right] \\
& P_{n a}(t)=P\left[S>a \mid S^{\prime}(t)\right]
\end{aligned}
$$

Klaidingo aliarmo tikimybė $P_{\mathrm{ka}}(t)$ laiko momentu $t$ yra tikimybe், kad įvykio $S$ ịvertis bus mažesnis-lygus kritiniam lygiui $a$, pagal EWS duotuoju momentu operuojamą informaciją apie spejamą tikimybę $S^{\prime}(t)$, priimant, kad buvo priim- 
tas sprendimas dèl aliarmo. Neįvykusio aliarmo tikimybė $P_{\text {na }}(t)$ yra tikimybè, kad įvykio $S$ ịvertis bus didesnis nei lygis $a$.

Siektina, kad sprendimo prièmimo objekte klaidos $\varepsilon(t)$ tikimybe būtu artina nuliui. Tam užtikrinti ịvedamas tinklo infrastruktūros virtualizacijo objektas (5.2 pav.). Jo tikslas yra sprendimo prièmimo objekte apdorojamą informaciją apie ịvykius sumodeliuoti virtualioje tinklo infrastruktūros aplinkoje, tokiu būdu patvirtinant arba paneigiant tikimybę ịvykti ịvykiui $S^{\prime}(t)$. Tinklo infrastruktūros virtualizacijos sprendimai ir taikymai nagrinèti 4 skyriuje.

Duomenų bazè (DB) yra aliarmų archyvas. Jeigu sprendimo prièmimo objekte susidaro situacija atitinkanti ankstesnius ịvykius iš DB, toliau sektini veiksmai pagal analogiją.

Aliarmo sklaidos objekto tinklas yra perduoti (paskleisti) informaciją apie kritinę situaciją. Šioje vietoje svarbu komunikacijos kanalo pasirinkimas (tai gali būti GSM tinklo SMS pranešimai ar dedikuotas tinklalapis internete) bei tikslinè adresatu grupe (pavyzdžiui IPT ar AS valdytojai).

Reziumuojant galima teigti, kad sprendimo prièmimo objekto efektyvumą lemia: laikas $t$ per kuri informacija pasiekia objektą (trumpas $t$ laikotarpis sudaro geresnes galimybes reagavimo veiksmams); aliarmo patikimumas (maksimaliai sumažinta klaidos $\varepsilon(t)$ tikimybė); prevencinių veiksmų tikslumas (IIS suformuotame įspejjime numatytos IS atnaujinimų ir koregavimų rekomendacijos).

\subsubsection{Išankstinio įspejjimo sistemos taikymas}

Dèl šalies interneto tinklo savybių, tokių kaip sava kalba, tinklo topologija, IS charakteristikos ir pan., IIS taikymas praktikoje sutinkamas atskiruose regionuose.

Lietuvoje IIS kuriama Ryšių reguliavimo institucijos bazèje. Kadangi ši institucija atlieka nacionalinio CERT funkcijas, IIS turi privalumą disponuoti informacija apie saugumo incidentus regiono IPT tinkluose. Padengiamas incidentų tyrimo objektas duomenų analizès lygyje (5.2 pav.). Tarpvalstybinių sutarčių pagrindu IIS turi prièjimą prie didžiujų IS kompanijų (tokių kaip Microsoft) programų pažeidžiamumų duomenų bazių (pažeidžiamumų analizės objektas 5.2 pav.). Šioje IIS pritaikius aukščiau sudarytą sprendimų prièmimo modelị, IIS veikla taptų labiau preciziška. 


\subsection{Organizacinès priemonès}

\subsubsection{Incidentụ valdymo efektyvumas}

Efektyvus reagavimas ị saugumo incidentus yra svarbus ir kritiškai reikalingas tinklo operatoriui procesas, kad būtų užtikrintas veiklos tęstinumas ir QoS. Naudojamas incidentų valdymo CERT modelis leidžia minimizuoti incidento ar kibernetinès atakos poveiki tinklo infrastruktūrai bei atstatyti prarastą QoS.

Lietuvoje CERT modelis pirma kartą igyvendintas 1998 metais Lietuvos mokslo ir studijų institucijų kompiuterių tinkle LITNET. LITNET-CERT pagrindinè paskirtis - mažinti grèsmes, kylančias dèl LITNET tinkle teikiamų paslaugų saugumo pažeidimų (LITNET 2011). 2006 metais veiklą pradejjo Lietuvos Respublikos nacionalinis elektroninių ryšių tinklų ir informacijos saugumo incidentų tyrimo padalinys (CERT-LT), kuris atlieka Lietuvos interneto tinklų ir informacijos saugumo incidentų tyrimus, veiksmų koordinavimą sprendžiant incidentus, rengia rekomendacijas apie grésmes (RRT 2011). CERT-LT atlieka incidentų valdymą visuose regiono interneto AS (5.1 lentelè).

5.1 lentelè. Incidentų statistika Lietuvos interneto AS tinkle

Table 5.1. Incidents statistics within Lithianian internet AS network

\begin{tabular}{|l|l|}
\hline Laikotarpis & $\begin{array}{l}\text { Registruotu incidentų } \\
\text { skaičius }\end{array}$ \\
\hline 2006 & 93 \\
\hline 2007 & 225 \\
\hline 2008 & 343 \\
\hline 2009 & 12588 \\
\hline 2010 & 10050 \\
\hline
\end{tabular}

Svarbu pastebèti, kad 2009 metais CERT-LT organizacinèje struktūroje idiegtas optimizuotas CERT modelis, aprašytas šio darbo 1 skyriuje. Organizacinès CERT modelio priemonès sudarè sąlygas ženkliai padidinti reagavimo i incidentus skaičių. Statistiškai apie 37 kartus (5.1 lentelè).

CERT modelis orientuotas reaguoti i saugumo incidentus, t. y. i bet kurio tipo incidentus keliančius grèsmę informacinei sistemai, tinklui ar perduodamos juo informacijos saugumui. Tačiau incidentu keliamos pasekmès tinklo infrastruktūrai, gali ženkliai skirtis priklausomai nuo incidento pobūdžio. Nagrinėjant šio skyriaus kontekste, priežiūros/reguliavimo institucijos veiksmai reikalingi tada, kai kyla rizika interneto tinklo funkcionalumui/junglumui. Tinklo pažeidžiamumo lygiui ịvertinti siūlo remtis slenksčiais aprašytais 5.2 lentelèje. 
Svarbu išlaikyti fizinị tinklo infrastruktūros saugumą. Kabeliai, maršrutizatoriai ir kita tinklo įranga turi būti tinkamai apsaugota nuo vandalizmo atvejų, vagysčių ir t. t.

Prie fizinio saugumo reikia priskirti ir elektros energijos tiekimo užtikrinimą tinklo infrastruktūros elementams. Standartiškai dyzeliniai generatoriai rezerviniam telekomunikacijų mazgų maitinimui nustatyti $72 h$ veikimui (Clarke 2010).

5.2 lentelè. Tinklo pažeidžiamumo rizikos slenksčiai

Table 5.2. AS types distribution

\begin{tabular}{|c|c|c|c|c|c|}
\hline & $<2$ val & $>2$ val. & $>4$ val. & $>6 \mathrm{val}$ & $>8$ val. \\
\hline$<2 \%$ vartotoju & nedidelè & nedidelé & nedidelè & vidutiné & didelè \\
\hline$>2 \%$ vartotoju & nedidelè & nedidelè & vidutinè & didelè & didelè \\
\hline$>5 \%$ vartotojų & nedidelè & vidutinè & didelé & didelè & didelè \\
\hline$>10 \%$ vartotojų & vidutinè & didelè & didelè & didelè & didelè \\
\hline$>15 \%$ vartotojų & didelè & didelè & didelè & didelè & didelè \\
\hline
\end{tabular}

\subsubsection{Topologijos balansavimas}

Darbe (Wu 2007) analizuojant interneto maršrutizavimo sisteminius ypatumus ir pažeidimų modelius padarytos išvados, kad tinklo topologija turi patikimumo trūkumų vietose kur tinklo segmento pralaida siauresnè nei turètų būti pagal pikinius duomenų srautus. Taip pat patikimumas nukenčia dèl įvykstančių maršrutizavimo tarp AS klaidų.

Analizuojant interneto infrastruktūrą 2 skyriuje nustatyta, kad atlikus AS klasifikaciją didžioji dalis Lietuvos interneto tinklo topologijoje yra Vartotojiško AS tipo (81\%), o ryšių tipų klasifikacija parodè, kad Lietuvos interneto infrastruktūroje vyrauja lygiaverčių mainų tipo sąryšiai tarp AS (76 \%). Daroma išvada, kad Lietuvos interneto tinklo infrastruktūra susiformavusi neproporcingai, tai sukelia papildomas rizikas tinklo veiklos patikimumui.

Didelio masto kibernetiniu atakų (PAAA) prevencijai CERT modelis nèra pakankamai efektyvus (Nazario 2010). Kibernetinių atakų eksperimentai Lietuvos interneto infrastruktūrai (4 sk.) patvirtina tokias prielaidas. Tokiu atveju alternatyvus rezervinis jungčių su tarptautinèmis AS tinklas būtų efektyvus sprendimas. Toks tinklas regiono interneto perimetro apsaugai laikomas kaip 
rezervinis ir aktyvuojamas (leidžiama prisijungti ir naudotis IPT), kai EWS registruoja reikšmingus tinklo infrastruktūros pažeidimus.

Atsižvelgiant ị tinklo topologijos analizę ir atliktų tyrimų rezultatus, reikia siekti subalansuoti tinklo topologiją. Tam pasiekti siūlomos sekančios priemonès:

1. Padidinti Tranzitinių AS ir tranzito ryšio linijų santykị bendroje tinklo topologijoje.

Tinklo topologijoje dominuoja Vartotojiško tipo AS, kurių junglumas nusileidžia Tranzitinėms AS. Lygiaverčių mainų linijoms galioja tas pats principas. Papildomas tranzitinių jungčių įvedimas ị regiono tinklo infrastruktūrą, fiziškai padidintų Vartotojiško tipo AS junglumą. Kitas metodas yra lygiaverčių mainų linijos tipą pakeisti tranzitine. Taip pagerètų tarptinklinių sujungimų charakteristikos, duomenų srautai turètų daugiau perdavimo kelio variantų.

2. Nustatyti tranzito ryšio linijas, kuriose realūs duomenų srautai 50-ia ar mažiau procentų išnaudoja maksimalias linijų pralaidas.

Sudaryti regiono interneto tinklo valdymo planą, kuris tokias linijas išnaudotų esant netipiškai išaugusiems duomenų srautams tinkle (pavyzdžiui, didelio masto kibernetinių atakų atveju) ar dèl eilès elementų gedimų tinkle susidarius perkrovoms. Esant kritiniai situacijai tinkle, tokių linijų operatoriai (IPT) turètų priimti ir tranzitu praleisti duomenų srautus iš tų IPT, kurių turimų veikiančių linijų pralaidumai nepakanka. Tokio plano veikla užtikrintų regiono tinklo vientisumo palaikymą.

3. Praplèsti tarptautinių kanalų pralaidą.

Regiono tarptinklinių sujungimų su kitų regionų AS skaičius ir jų pralaida yra ribota. Egzistuoja tikimybè, kad dèl kibernetinių atakų bendra tokių jungčių pralaida bus išnaudota maksimaliai. Botnet tinkluose gali veikti keletas šimtu tūkstančių nuotoliniu būdu valdomų pažeistų kompiuterių. Jeigu priimtume, kad vienas toks kompiuteris generuoja bent $1 \mathrm{Mbit} / \mathrm{s}$ srautą atakos metu, sąlyga, kad bendras Lietuvos regiono tarptautinių kanalų pralaidumas tyrimo metu buvo 60 Gbit/s būtų patenkinta prie 60 tūkstančių botnet tinklo. Todèl tokios atakos ir jos poveikio regiono tinklui tikimybė yra reali. Minètų jungčių pralaida turètų būti praplèsta arba rezerviniai pralaidumai paruošti atvejams kai reikia akumuliuoti netipinius duomenų srautus.

\subsubsection{Interneto protokolų saugumo plètiniai}

Gerai žinoma, kad DNS yra vienas pagrindinių interneto protokolų, užtikrinantis domenų vardų sąryšį su IP adresacija. DNS protokolo apsaugos pagrindinė spraga yra autentifikacijos trūkumas. Ši problema sprendžiama įvedant autentifikaciją ir duomenų vientisumo apsaugą bei naudojant perduodamų duomenų šifravi- 
mą (Arends 2004). DNS protokolo saugumo plètinys DNSSEC (angl. Domain Name System Security Extensions) sprendžia ši uždavinị.

DNSSEC sistema veikia skaitmeniniu būdų pasirašant atsakymus ị DNS paiešką, naudojant viešojo rakto kriptografiją (Lammle 2009). Kad įgyvendinti tai keletas naujų DNS ịrašų buvo sukurta įskaitant RRSIG, DNSKEY, DS ir ns DNS ịrašus. Kuomet naudojama DNSSEC, kiekvienas atsakymas ị DNS užklausa turès RRSIG DNS ịrašą. RRSIG ịrašas yra skaitmeninis parašas, naudojamas atsakymams iš DNS šaltinio. Skaitmeninis parašas gali būti patikrintas, nustatant tinkamą viešajį raktą, kuris yra DNSKEY įraše. Pagal gautus rezultatus apsaugotas DNS klientas gali nustatyti ar gautas atsakymas iš DNS serverio yra geras (saugus), taip pat ar DNS serveris palaiko DNSSEC, bei nustatyti ar yra padaryta kokia tam tikra klaida. Teisingas DNSKEY ịrašas yra nustatomas autentifikavimo grandinejje, nustatant teisingą viešą raką. Šis viešas raktas gali būti panaudotas nustatyti DS (designated signer) įrašą. DS įrašas pagrindiniame domene (DNS zone) toliau gali būtu naudojamas nustatant DNSKEY ịrašą subdomene, kur toliau gali turèti kitus DS įrašus nustatant tolimesnius subdomenus.

DNSSEC protokolas nėra plačiai taikomas, nes jis neišsprendžia visų DNS protokolo problemų. Pagrindinès problemos siejamos su programinès ịrangos suderinamumas su DNSSEC. Kadangi DNSSEC yra gan nauja technologija todèl programinès įrangos palaikymas skiriasi nuo DNS technologijos palaikymo. Šiuo metu yra labai mažai programinès ịrangos kuri galètų visiškai palaikyti DNSSEC. Protokolas reikalauja nuolatinio administravimo. Kuomet nenaudojama DNSSEC, užtenka sukonfigūruoti vardų serverị ir užregistruoti domenus. DNSSEC parašai galioja tik tam tikrą laikotarpi ir turi būti atnaujinami. Raktai naudojami parašams turi būti periodiškai keičiami.

DNSSEC suderinamumo problemos su esamais sprendimais. DNSSEC gali susidurti su tokiom problemom, kaip dinaminiai atnaujinimai, DNS valdymo programomis, specialios konfigūracijos Spilt-DNS, bei maršrutizatoriai ir ugniasienėm kurios nepalaiko DNSSEC.

DNSSEC standartizavimas nèra visiškai baigtas. Techninio realizavo dalys DNSSEC yra dauguma standartizuotos, tačiau organizavimo ir administravimo standartizavimo užbaigimo dar nèra. Reikia standartizuoti tokius dalykus kaip rakto paskirstymas, rakto kaitaliojimas ir perejjimas nuo vieno vardų serverio prie kito.

Internete naudojamas maršrutizavimo BGP protokole egzistuoja saugumo spragos (Sriram 2006). Incidentas, kai 2010 metais eksperimento būdų inicijuotas neįprastai didelis fiktyvių maršrutų lentelių atnaujinimas, sukèlė didelio skaičiaus maršrutizatoriu gedimus (Hall 2011). Tinkle jie nebuvo matomi (kaimyniniai maršrutizatoriai neturejo jų pasiekiamumo informacijos), todèl adresuoti duomenys jų nepasiekdavo. Incidento afektas truko apie $2 h$. 
BGP protokolas yra pagrindinis interneto tarptinkliniams sujungimams organizuoti tarp AS. AS maršrutizatoriai keičiasi informacija (sujungimų lentelèmis) su kitomis AS, kurias jie gali tiesiogiai pasiekti. BGP protokolo pagrindu vykstantis maršrutizavimo lentelių atnaujinimas nėra centralizuotai valdomas. Sujungimų lentelès iš esmès yra IP adresacijos blokai. Informacijos apsikeitimo grandinė tęsiasi nuo vienos AS ị kitą, su kiekviena AS numatytųjų maršrutų apimtis didejja. Joks kitas protokolas junglumui nèra naudojamas. BGP protokolo pažeidžiamumai susiję su nenumatyta sąlyga maršrutizavimo lentelių tikrumui patikrinti (Zao 2002) ir nagrinèti 4 skyriuje.

BGP pažeidžiamumo problematika spręsta protokolo saugumo plètiniais: SBGP (Kent 2003) ir soBGP (White 2003). Iš kurių BGPSEC (Bush 2011) sprendimas IPT pradedamas taikyti praktikoje. BGPSEC viešojo rakto infrastruktūrą, kuri užtikrina maršrutų sietị su AS bei ịveda kodavimą. Atliekama kelio autorizacija, kuri numato, kad kalias ị AS $x$ iš tikro priklauso šio AS numatytajai IP adresacijai $x$. BGPSEC apsaugo nuo AS, nurodančių neteisingus kelius ar AS neteisètai ịterpiančių save ị numatytąji kelio maršrutą.

\subsection{Penktojo skyriaus išvados}

1. Interneto infrastruktūros stochastinis vystymasis remiantis neutralumo principais neužtikrina reikalaujamo patikimumo. Reikalingos sisteminès ir operatyvinès priemonès užtikrinti minimalius tinklo saugumo ir patikimumo reikalavimus.

2. Siūloma prevencinė priemonè, išankstinio ịspẻjimo sistema (IIS), apjungia interneto topologijos, kritinių tinklo infrastruktūros elementų bei kibernetinių atakų simuliacijų tyrimų rezultatų principus. Sudaryta IIS sistema remiasi interneto infrastruktūrai koncepcija paremta pažeidžiamumų analizès, CERT incidentų tyrimais bei SNMP stebėsenos priemonių naudojimu.

3. IIS aliarmo sprendimo prièmimo objekto efektyvumą lemia: laikas $t$ per kuri informacija pasiekia objektą (trumpas $t$ laikotarpis sudaro geresnes galimybes reagavimo veiksmams); aliarmo patikimumas (maksimaliai sumažinta klai$\operatorname{dos} \varepsilon(t)$ tikimybè); prevencinių veiksmų tikslumas.

4. Regionineje sistemoje sudarytas EWS modelis geriausiai tinkamas pozicionuoti nacionalinio ryšių reguliatoriaus bazèje. Taip būtų užtikrinamas nešališkumas ir visų sektorių IS (valstybinio, privataus) padengiamumas. 


\section{Bendrosios išvados}

1. CERT modelis, efektyvus atskirų incidentų tyrime, nesudaro reikiamų prielaidų bendram interneto tinklo saugumo ir patikimumo klausimui išspręsti. Interneto pažeidžiamumai kelia poreikị kurti ir vystyti naujas, pro-aktyvias (prevencines) priemones, kurios sudarytų sąlygas kontroliuoti bei neutralizuoti kibernetinių incidentų bei atsitiktinių gedimų ịtaką interneto veiklos patikimumui.

2. Interneto tinklo topologinès struktūros patikimumo analizei geriausiai tinka ryšių grafų sudarymo metodai, išskiriant mazgų laipsnius, mazgų laipsnių pasiskirstymą ir grupavimą.

2.1. Pagal sudarytą autonominių sistemų (AS) ir jungčių klasifikaciją, Lietuvos interneto tinklo infrastruktūroje dominuoja Vartotojiško tipo AS $(81 \%)$ ir lygiaverčiu mainų tipo sąryšiai tarp AS (76\%);

2.2. Pagal mazgo laipsnių pasiskirstymą, Lietuvos interneto tinklo topologijoje yra tik vienas mazgas valdantis 47 tranzitinių jungčių, o $76 \%$ mazgų valdo tik 1-2 tranzitines jungtis su kitomis AS.

3. Interneto tinklo infrastruktūros pažeidžiamumo analizè pagal kritinių ir $\eta$ kritinių mazgų, kritinių ir $\kappa$-kritinių linijų paieškos metodiką identifikuoja regiono interneto tinklo kritinius elementus bei sudaro prielaidas ịvertinti jų kritiškumą. Šių elementų stebėsena paremta modeliu, naudojančiu SNMP protokolą, užtikrina centralizuotą tinklo infrastruktūros junglumo stebėseną. 
Sudarytą metriką pritaikius Lietuvos interneto tinklo infrastruktūrai, identifikuoti 4 kritiniai mazgai ir $3 \eta$ - kritiniai mazgai, bei nustatytos 26 kritinès linijos ir 2 regiono interneto potinkliai, kurių tarpe yra $\kappa$ - kritinès linijos.

4. Sukurtas virtualus regiono interneto tinklo modelis, kurio pagrindu, eksperimentiškai vertinamas tinklo patikimumas naudojant kibernetinių atakų scenarijus. Bandyme (kibernetinès atakos vektorius iš tarptautinių AS i nacionalinį regiono tinklą) nustatyta 3 AS (tinklo mazgai) ir 4 tarptinklinių sujungimų linijos, kurios patyrė maksimalias srautų apkrovas. Pažeistos jungtys ir AS sutampa su kritiniais mazgais ir kritinemis linijomis nustatytais pagal teorini modeli.

5. Išankstinio ịspèjimo sistema ir tinklo topologijos balansavimo priemonès sudaro prielaidas sustiprinti regiono interneto tinklo infrastruktūros patikimumą. 


\section{Literatūra ir šaltiniai}

Albert R., Barabasi A. L. 2002. Statistical mechanics of complex networks. Reviews of Modern Physics 74, P. 47-97.

Alberts C., Dorofee A., Killcrece G., 2004. Defining Incident Management Processes for CSIRTs: A Work in Progress. Software Engineering Institute Carnegie Mellon University.

Alduán M., Álvarez F., Zahariadis Th., Nikolakis N., Chatzipapadopoulos F., Jiménez D., Manuel Menéndez J. 2010. Architectures for Future Media Internet. 2nd International Conference on User Centric Media.

Allman M., Christenson K., Nordman B., Paxson V. 2007. Enabling an Energy-Efficient Future Internet Through Selectively Connected End Systems. HotNets-VI.

Ando R., Takefuji Y. 2007. Parallel analysis for lightweight network incident detection using nonlinear adaptive systems. National Institute of Information and Communication Technology, Japan. IFIP International Conference on Network and Parallel Computing Workshops, $7 \mathrm{p}$.

Arakawa Sh., Katou J., Murata M. 2003. Design method of Logical Topologies with Quality of Reliability in WDM Networks. Osaka University.

Arends R., Austein R., Larson M., Massey D., Rose S. 2004. DNS Security Introduction and Requirements. Internet Engineering Task Force. 
Ball P. 2002. Hubcaps Could Squash STDs. http://www.nature.com/nsu/010823/0108236.html. Žiūrèta 2010-10-10.

Barabási A., Albert R. 1999. Emergence of Scaling in RandomNetworks. Science Magazine, 286: 4509.

Barabási A. 2002. The Physics of the Web. http://physicsweb.org/article/world/14/7/9. Žiūrèta 2010-10-10.

Bondy J. A., Murty U. S. R. 1976. Graph Theory with Applications, P. 270.

Brohée S., Faust K., van Helden J. 2009. Network Analysis Tools (NeAT) Tutorial. RSAT.

Bush R. 2011. BGPsec Operational Considerations.

Case J., Fedor M., Schoffstall M., Davin J. 1990. A Simple Network Management Protocol (SNMP). Internet Engineering Task Force, RFC 1157.

Chandramouli R., Rose S. 2009. Secure Domain Name System (DNS) Deployment Guide. Recommendations of the National Institute of Standards and Technology. - P. 118.

Chang H., Govindan R., Jamin S., Shenker S. J., Willinger W. 2004. Towards capturing representative AS-level Internet topologies. Elsevier Computer Networks Journal 44(6), P. 737-755.

Clarke R., Knake R. 2010. Cyber War: The Next Threat to National Security and What to Do About It. HarperCollins.

Chen Q., Hyunseok C., Govindan R., Jamin S., Shenker S., Willinger W. 2002. The Origin of Power Laws in Internet Topologies Revisited. Proceeedings of IEEE Infocom.

Condon E., Cukier M., He T. 2007. Applying Software Reliability Models on Security Incidents. Center for Risk and Reliability Department of Mechanical Engineering University of Maryland, College Park. 18th IEEE International Symposium on Software Reliability Engineering, 10 p.

Dharmapurikar S., Krishnamurthy P., Sproull T., Lockwood J. 2003. Deep packet inspection using parallel bloom filters. IEEE High Performance Interconnects, P. 44-51.

Dimitropoulos X., Krioukov D., Vahdat A., Riley G. 2009. Annotations in Modeling Complex Network Topologies. TOMACS, Vol. 19, No. 4, Article 17.

Dimitropoulos X., Krioukov D., Riley G. 2006. Revealing the Autonomous System Taxonomy: The Machine Learning Approach. PAM workshop paper source.

Dohoon K. 2008. Reliability and Risk Analysis of the Internet: Case of Korean Internet Interconnections. IEEE SoSE.

Dolev D., Sugih J., Osnat M., Shavitt Y. 2006. Internet resiliency to attacks and failures under BGP policy routing. Computer Networks, Vol. 50, Issue 16, P. 3183-3196.

Ekmanis M. 2010. Graph Mining for Traffic Source Similarity Search. Electronics and Electrical Engineering. - Kaunas: Technologija - No. 5(101). - P. 39-42. 
Erdös P., Rényi A. 1960. On the Evolution of Random Graphs. Publication of the Mathematical Institute of the Hungarian Academy of Sciences.

FMIA-TT 2011. Future Media Internet Architecture Reference Model. NextMEDIA consortium FP7 ICT-249065.

Gao L., Rexford J. 2000. Stable Internet Routing Without Global Coordination. ACM SIGMETRICS.

Garšva E., Skudutis J. 2004. Secure Computer System Design. Electronics and Electrical Engineering. No. 6 (55). P. 43-48.

Golling M., Stelte B. 2011. Requirements for a Future EWS - Cyber Defence in the Internet of the Future. CCD COE Publications.

Goodger A., Glorioso A., Lioy A., Katsumi B. 2011. Security \& Resilience in Governmental Clouds. ENISA.

Grasso V., Beck J., Manfredi G. 2007. Automated decision procedure for earthquake early warning. Journal of Engineering Structures.

Hadgkiss J. 2006. Computer Security Incident Response Teams: Exploring the Incident Learning Capability. The University of Melbourne 83 p.

Hanley M., Dean T., Schroeder W. 2011. An Analysis of Technical Observations in Insider Theft of Intellectual Property Cases. Carnegie Mellon University, CMU/SEI-2011TN-006.

Hall C., Clayton R., Anderson R., Ouzounis E. 2011. Inter-X: Resilience of the Internet Interconnection Ecosystem. ENISA.

Harju T. 2007. Graph Theory. University of Turku Lecture Notes.

Hawkinson J., Bates T. 1996. Guidelines for creation, selection, and registration of an Autonomous System. RFC 1930.

Herman I. 2000. Graph Visualization and Navigation in Information Visualization: a Survey, IEEE Transactions on Visualization and Computer Graphics, Vol. 6.

Jelinskis J., Lauks G. 2009. Detection of Trends of Internet Traffic using Sequential Pattern. Electronics and Electrical Engineering. - Kaunas: Technologija - No. 5(93). - P. 3-6.

Juknius J., Čenys A. 2011. BOTNET propagation via public websited detection algorithm. Science - future of Lithuania: Electronics and electrical engineering. Vilnius: Technika. ISSN 2029-2341. T. 3, nr. 1 (2011), p. 29-32.

Lauks G., Jeļinskis J. 2009. Metamodelling of Queuing Systems using Fuzzy Graphs. Electronics and Electrical Engineering. - Kaunas: Technologija - No. 4(92). - P. 61-64.

Lammle T. 2009. CompTIA Network+. Willey Publishing, 892p.

Libicki M. 2009. Cyberdeterrence and Cyberwar. Rand Corporation.

LITNET 2011. https://cert.litnet.lt/. Žiūrèta 2010-10-10. 
Lohr S., Markoff J. 2006. Windows Is So Slow, but Why? New York Times.

Magoni D., Pansiot J. 2002. Analysis of the Autonomous System Network Topology. http://www.acm.org/sigcomm/ccr/archive/2001/jul01/ccr-200107-magoni.pdf. Žiūrèta 2010-10-10.

Mahajan R., Wetherall D., Anderson T. 2002. Understanding BGP Misconfiguration. In Proc. of ACM SIGCOMM.

Medina A., Matta I., Byers J. 2000. On the Origin of Power Laws in Internet Topologies. ACM SIGCOMM Computer Communication Review 30. P: 18-28.

Masurkar V. 2003. Responding to a Customer's Security Incidents-Part 1: Establishing Teams and a Policy. Sun Microsystems $24 \mathrm{p}$.

Mirkovic J., Martin J., Reiher P. 2004. A Taxonomy of DDoS Attacks and DDoS Defense Mechanisms. UCLA CSD Technical Report. - No. 020018.

Montoya J., Solé R. 2002. Small World Patterns in Food Webs. http://arxiv.org/PS_cache/cond-mat/pdf/0011/0011195.pdf. Žiūrèta 2010-10-10.

Nazario J. 2010. Politically Motivated Denial of Service Attacks. CCDCOE.

Norton W. B. 2002. The Art of Peering: The Peering Playbook. http://arneillpy.sacramento.ca.us/ipv6mh/playbook.pdf.

Oliveira R., Pei D., Willinger W. 2010. The (in)Completeness of the Observed Internet AS-level Structure. IEEE/ACM Transactions on Networking.

Oliveira R., Zhang B., Zhang L. 2007. Observing the Evolution of Internet AS Topology. Proceedings of ACM SIGCOMM.

Owezarski P., Larrieu N. 2006. Measurement Based Approach of Congestion Control for enforcing a robust QoS in the Internet. LAAS-CNRS 7, IEEE, 0-7695-2649-7.

Pavilanskas L., Statkus A. 2010. Evaluation of TCP Acknowledgment Mechanism Influence on Router Performance. Electronics and Electrical Engineering. - Kaunas: Technologija. - No. 7(103). - P. 95-100.

Paul S., Pan J., Jain R. 2011. A Survey of the Research on Future Internet Architectures. IEEE Communications Magazine.

Paul S., Pan J., Jain R. 2010. Architectures for the Future Networks and the Next Generation Internet: A Survey. Computer Communications.

Paulauskas N., Garšva E. 2006. Computer System Attack Classification. Electronics and Electrical Engineering No. 2(66), P. 84-87.

Provos N., Holz T. 2007. Virtual Honeypots: From Botnet Tracking to Intrusion Detection. Addison-Wesley Professional.

Kajackas A., Pavilanskas L., Vindašius A. 2007. Synchronous Voice Applied Customer Access based on IEEE 802.11. Electronics and Electrical Engineering. - Kaunas: Technologija - No. 8 (80). - P. 23-28. 
Karygiannis A., Antonakakis E., Apostolopoulos A. 2006. Detecting Critical Nodes for MANET IDS. IEEE Computer Society.

Karun H. H. 2006. Security incidents handling and organizational models. Gjøvik University College Department of Computer Science and Media Technology, 24 p.

Kent S. T. 2003. Securing the Border Gateway Protocol. The Internet Protocol Journal, vol. 6 , no. 3 .

Killcrece G., Kossakowski K. P., Ruefle R., Zajicek M. 2003. Organizational Models for Computer Security Incident Response Teams (CSIRTs). Software Engineering Institute Carnegie Mellon University.

Knight S., Leblanc S. 2009. When not to pull the plug - the need for network countersurveillance operations. Cryptology and information security series Vol. 3, P. 226-237.

Kozierok C. M. 2005. The TCP/IP Guide. No Starch Press.

Kulikovs, M. Petersons E. 2009. Modeling the On-line Traffic Estimator in OPNET. Electronics and Electrical Engineering - Kaunas: Technologija,. - No. 7(95). - P. 8286.

Shimoda A., Goto S. 2007. Virtual Dark IP for Internet Threat Detection. APAN Network Research Workshop, p. 17-23.

Smith D. 2005. Reliability, Maintainability and Risk. 7th ed.: Elsevier.

Stubna M., Fowler J. 2002. An Application of the Highly Optimized Tolerance Model to Electrical Blackouts. http://www.chaos.cornell.edu/hot3.pdf. Žiūrèta 2010-10-10.

Strogatz S. 2001. Exploring Complex Networks. Nature 410. P:268-276.

Sriram K., Montgomery D., Borchert O., Kim O., Kuhn R. 2006. Study of BGP Peering Session Attacks and Their Impacts on Routing Performance. IEEE Journal on Selected Areas in Communications: Special issue on High-Speed Network Security, Vol. 24, No. 10, p. 1901-1915.

Subramanian L., Agarwal S., Rexford J., Katz R. H. 2002. Characterizing the Internet hierarchy from multiple vantage points. IEEE Infocom paper source.

Sufatrio, Yap R., Zhong L. 2004. A Machine-Oriented Integrated Vulnerability Database for Automated Vulnerability Detection and Processing. LISA XVIII, p. 47-58.

Thonnard O. 2010. A multi-criteria clustering approach to support attack attribution in cyberspace. PhD Thesis, Ecole Nationale Supérieure des Télécommunications.

The Swedish Urban Networks Association (SUNA) 2004. Robust nodes recomendations. Rekhter Y., Li T., Hares S. 2006. Border Gateway Protocol 4. RFC 4271, Internet Engineering Task Force.

RRT 2011. https://www.cert.lt/. Žiūrèta 2010-10-10.

Zhang B., Liu R., Massey D., Zhang L. 2005. Collecting the Internet AS-level topology. ACM SIGCOMM Computer Comm. Review (CCR), 35(1):53-61. 
Zhao X., Pei D., Bush R., Massey D., Mankin A. 2002. Observation and Analysis of BGP Behavior under Stress. IMW'02, 2002.

Wagner A. 2008. Robustness and Evolvability: A Paradox Resolved. ProcBiolSci, vol. 275, p. 91-100.

Waldbusser S. 1995. Network Monitoring Management Information Base. Carnegie Mellon University.

Wang K., Stolfo S. 2004. Anomalous payload-based network intrusion detection. Recent Advances in Intrusion Detection, p. 203-222.

Watal A. 2011. A Co-Regulatory Approach to Reasonable Network Management. Journal of Information Policy, Vol. 1, pp. 155-173.

Watts D., Sorogatz S. 1998. Collective Dynamics of Small World Networks. Nature 393 P:440-442.

West-Brown M. J., Stikvoort D., Kossakowski K. P., 2003. Handbook for Computer Security Incident Response Teams (CSIRTs). Software Engineering Institute Carnegie Mellon University.

White R. 2003. Securing BGP Through Secure Origin BGP. The Internet Protocol Journal, vol. 6, no. 3 .

Wiik J., Gonzalez J. J., Kossakowski K. P. 2005. Limits to Effectiveness in Computer Security Incident Response Teams.

Wu J., Zhang Y., Mao Z., Shin K. 2007. Internet routing resilience to failures: analysis and implications. In Proc. of ACM CoNext. 


\section{Autoriaus publikacijos disertacijos tema}

\section{Straipsniai recenzuojamuose mokslo žurnaluose}

Rainys R., 2006. Network and Information Security. Assessments and Incidents Handling // Electronics and Electrical Engineering. - Kaunas: Technologija. - ISSN 1392 1215. - No. 6(70). - P. 69-74.

Kajackas A., Rainys R., 2010. Internet Infrastructure Topology Assessment // Electronics and Electrical Engineering. - Kaunas: Technologija. - ISSN 1392 - 1215. - No. 7 (103). - P. 91-94.

Kajackas A., Rainys R., 2011. Estimation of Critical Components of Internet Infrastructure // Electronics and Electrical Engineering. - Kaunas: Technologija. - ISSN 1392 - 1215. - No. 4(110). - P. 35-38.

Kajackas A., Rainys R., Aputis A., 2011. Assessment of Cyber Attacks Influence over Internet Network // Electronics and Electrical Engineering. - Kaunas: Technologija. ISSN 1392 - 1215. - No. 7(113). - P. 89-92.

\section{Straipsniai kituose leidiniuose}

Rainys R., 2006 How Can NRA Contribute to the Improvement of IT Security // Information Security Solutions Europe, Conference material. - P. 426-432. 
Rainys R., 2007. Belaidžių tinklų saugumas įmonėse // Konferencijos INFORMACINĖS TECHNOLOGIJOS 2007 pranešimų medžiaga. - Kaunas, Kauno technologijos universitetas. - ISSN 1822-6337. - P. 234-239. 


\section{Priedai}

\section{A priedas. Pilna realios Lietuvos interneto tinklo topologijos schema}

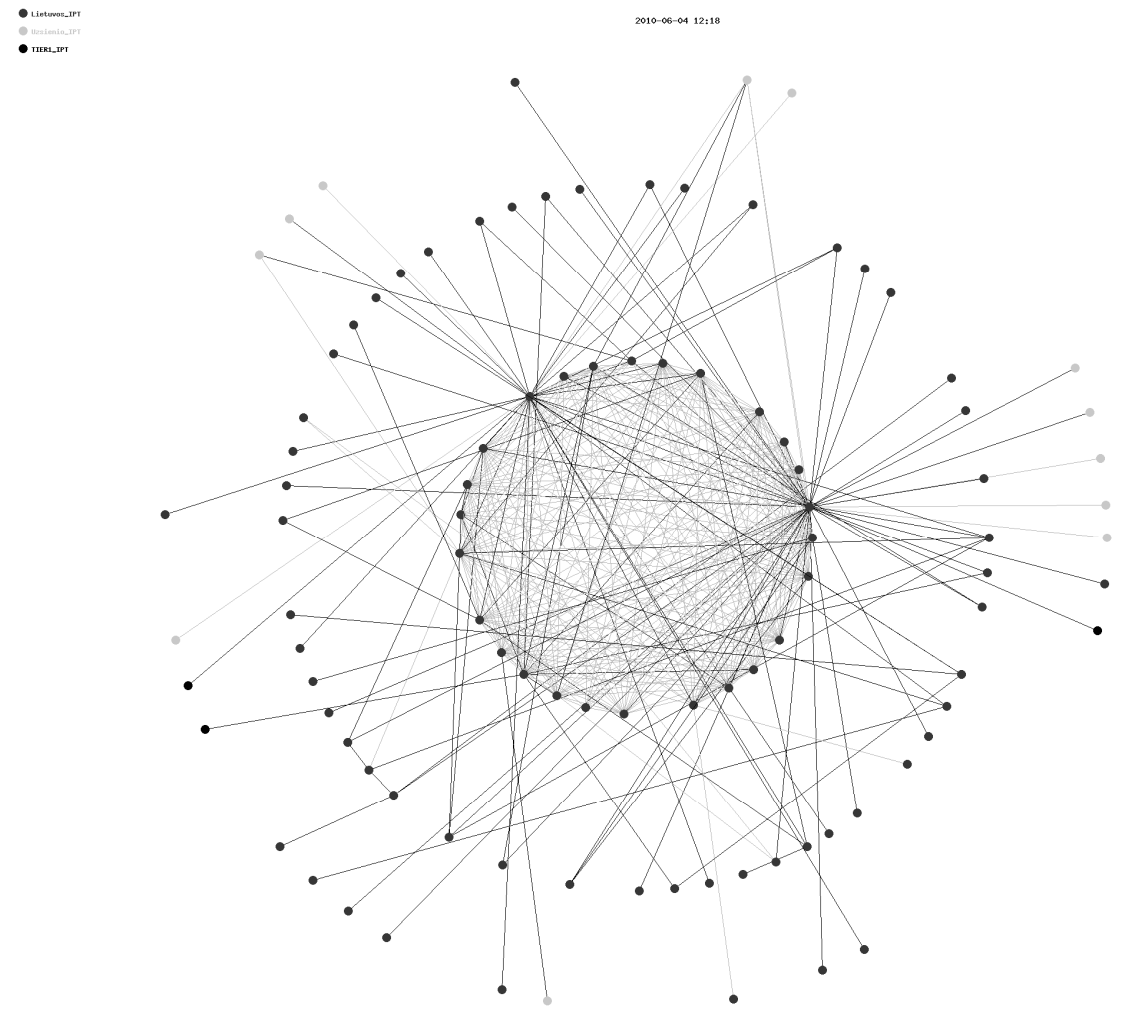

Stalviniai grafo žymėjimai: a) juodos linijos - tranzitinio tipo, žalios - lygiaverčių mainų; b) raudoni mazgai - regiono IPT, geltoni - tarptautiniai AS, juodi-Tier-1 AS 


\section{B priedas. Virtualus Lietuvos interneto tinklo modelis kibernetinių atakų eksperimentams}

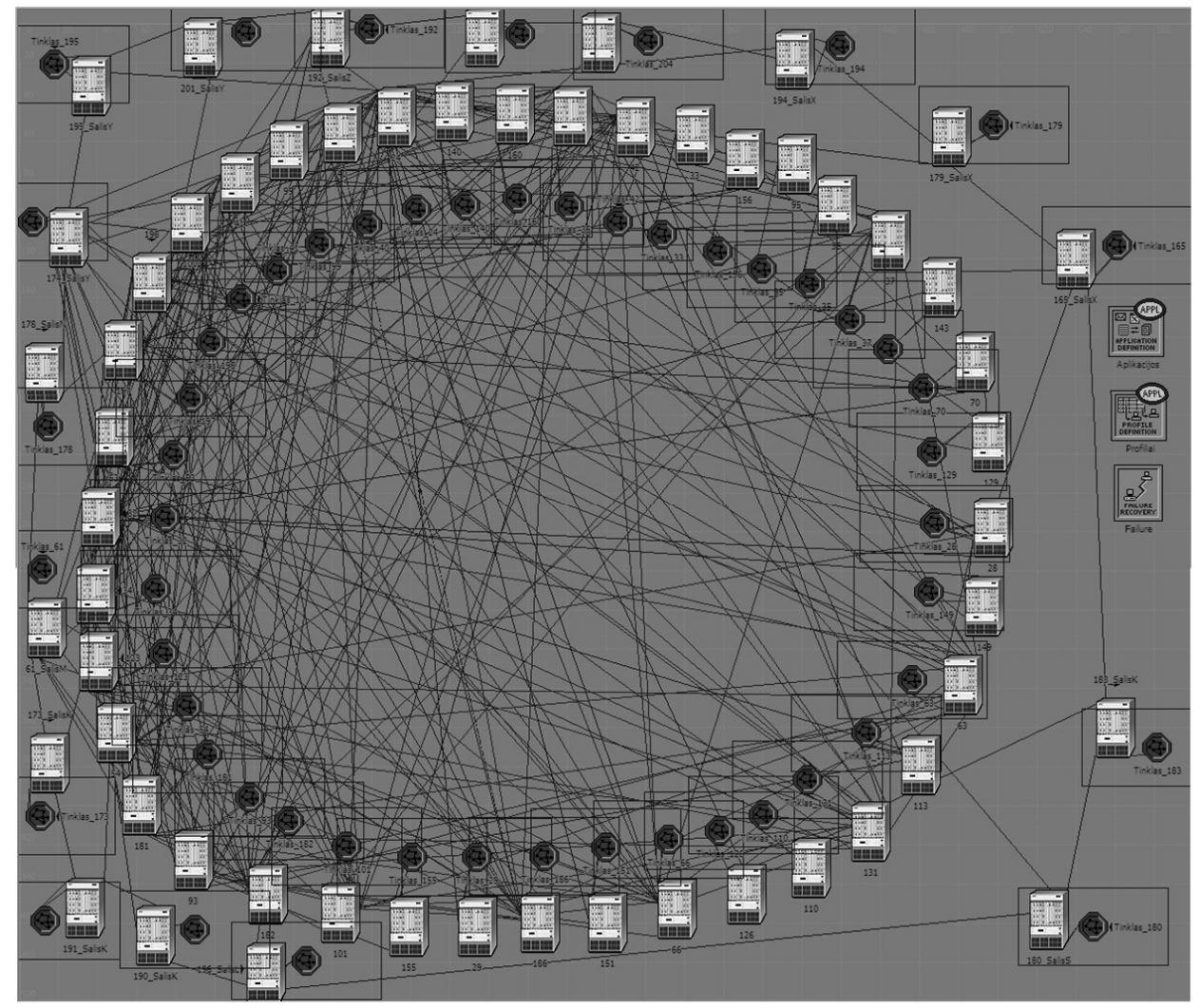

B priedo duomenų masyvo lentelè

\begin{tabular}{|l|l|}
\hline \multicolumn{1}{|c|}{ Tipas } & \multicolumn{1}{c|}{ Kiekis } \\
\hline Lygiaverčių mainų & 373 \\
\hline Tranzitinès & 117 \\
\hline Mazgai & 57 \\
\hline
\end{tabular}


Rytis RAINYS

REGIONŲ INTERNETO TINKLO INFRASTRUKTŪROS PATIKIMUMO TYRIMAI

Daktaro disertacija

Technologijos mokslai,

elektros ir elektronikos inžinerija (01T)

INVESTIGASION OF THE REGIONAL INTERNET NETWORK INFRASTRUCTURE DEPENDABILITY

Doctoral Dissertation

Technological Sciences,

Electrical and Electronic Engineering (01T)

201111 11. 7,25 sp. I. Tiražas 20 egz.

Vilniaus Gedimino technikos universiteto

leidykla „Technika“,

Saulètekio al. 11, 10223 Vilnius,

http://leidykla.vgtu.lt

Spausdino UAB „Ciklonas“

J. Jasinskio g. 15, 01111 Vilnius 